Assessment of Effectiveness of Geologic Isolation Systems

\title{
A Summary of FY-1978 \\ Consultant Input for Scenario Methodology Development
}
B. L. Scott
R. A. Craig
G. L. Benson
M. A. Harwell

November 1979

Prepared for the

Office of Nuclear Waste Isolation

under its Contract with the

U.S. Department of Energy

Pacific Northwest Laboratory

Operated for the U.S. Department of Energy

by Battelle Memorial Institute 


\title{
NOTICE
}

This report was prepared as an account of work sponsored by the United States Government. Neither the United States nor the Department of Energy, nor any of their employees, nor any of their contractors, subcontractors, or their employees, makes any warranty, express or implied, or assumes any legal liability or responsibility for the accuracy, completeness or usefulness of any information, apparatus, product or process disclosed, or represents that its use would not infringe privately owned rights.

The views, opinions and conclusions contained in this report are those of the contractor and do not necessarily represent those of the United States Government or the United States Department of Energy.

\author{
PACIFIC NORTHWEST LABORATORY \\ operated by \\ BATTELLE \\ for the \\ UNITED STATES DEPARTMENT OF ENERGY \\ Under Contract EY-76-C-06-1830
}

\begin{tabular}{|c|c|}
\hline \multicolumn{2}{|c|}{$\begin{array}{c}\text { Printed in the United States of America } \\
\text { Available from } \\
\text { National Technical Information Service } \\
\text { United States Department of Commerce } \\
5285 \text { Port Royal Road } \\
\text { Springfield, Virginia } 22151\end{array}$} \\
\hline Price: Printed Copy & $\because$ Microfiche $\$ 3.00$ \\
\hline -Pages & $\begin{array}{c}\text { NTIS } \\
\text { Selling Price }\end{array}$ \\
\hline $001-025$ & $\$ 4.00$ \\
\hline $026-050$ & $\$ 4.50$ \\
\hline $051-075$ & $\$ 5.25$ \\
\hline $076-100$ & $\$ 6.00$ \\
\hline $101-125$ & $\$ 6.50$ \\
\hline $126-150$ & 57.25 \\
\hline $151-175$ & $\$ 8.00$ \\
\hline $176-200$ & 59.00 \\
\hline $201-225$ & $\$ 9.25$ \\
\hline $226-250$ & $\$ 9.50$ \\
\hline 251.275 & $\$ 10.75$ \\
\hline $276-300$ & $\$ 11.00$ \\
\hline
\end{tabular}




\section{6}

Assessment of Effectiveness of Geologic Isolation Systems

A SUMMARY OF FY-1978 CONSULTANT INPUT

FOR SCENARIO METHODOLOGY DEVELOPMENT

$\begin{array}{ll}\text { Editors: } & \text { B. L. Scott } \\ & \text { G. L. Benson } \\ & \text { R. A. Craig } \\ & \text { M. A. Harwe } 11\end{array}$

November 1979

Prepared for the Office of Nuclear Waste Isolation

Under its Contract with

the U.S. Department of Energy

Contract EY-76-C-06-1830

Pac if ic Northwest Laboratory

Richland, Washington 99352 


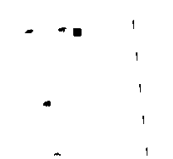

1

- 


\begin{abstract}
$\because \quad$ This research was supported by the Waste Isolation Safety Assessment Program (WISAP) conducted by Pacific Northwest Laboratory. The program was sponsored by the Office of Nuclear Waste Isolation, managed by Battelle Memorial Institute for the Department of Energy under Contract EY-76-C-06-1830. On 1 October 1979, WISAP became the Assessment of Effectiveness of Geologic Isolation Systems (AEGIS) Program and the Waste/Rock Interactions Technology (WRIT) Program. This report was issued by AEGIS.
\end{abstract}


$+$ 
TABLE OF CONTENTS

ACKNOWLEDGMENT •

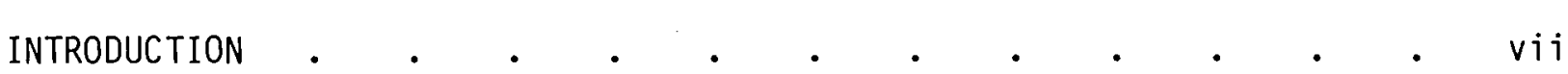

CHAPTER I - DISRUPTIVE EVENT ANALYSIS: VOLCANISM AND IGNEOUS

INTRUSION

by B. M. Crowe, Los Alamos Scientific Laboratory . . . . . I-1

CHAPTER II - PACIFIC NORTHWEST GEOMORPHOLOGY AND HYDROLOGY: RATES

AND PROBABILITIES OF SELECTED PROCESSES AND EVENTS

by D. W. Tubbs, University of Kansas . . . . . . . II-1

CHAPTER III - ANALYSIS OF THE SEISMIC HAZARD TO AN UNDERGROUND WASTE REPOSITORY

by L. H. Wight, TERA Corporation .

CHAPTER IV - GLACIOLOGICAL PARAMETERS OF DISRUPTIVE EVENT ANALYSIS

by $\mathrm{C}$. Bu11, Ohio State University . • . . • • • • . IV-1

CHAPTER $V$ - GEOLOGIC FACTORS IN THE ISOLATION OF NUCLEAR WASTE:

EVALUATION OF LONG-TERM GEOMORPHIC PROCESSES AND EVENTS

by S. J. Mara, Stanford Research Institute . . . . . . V-1

CHAPTER VI - LONG-TERM METEORITE HAZARDS TO BURIED NUCLEAR WASTE

Report 2

by W. K. Hartmann, Planetary Sciences Institute . • • • . VI-1

CHAPTER VII - PRELIMINARY SUBSURFACE HYDROLOGIC CONSIDERATIONS:

COLUMBIA RIVER PLATEAU PHYSIOGRAPHIC PROVINCE, USA

by M. D. Veatch, Shannon and Wilson, Inc. • . . . . . VII-1

CHAPTER VIII - GENERAL SUBSURFACE GEOLOGY OF SOUTHEASTERN NEW MEXICO

WITH SPECIAL REFERENCE TO ITS STRUCTURAL STABILITY

by J. Hills, University of Texas, El Paso . . . . . . . VIII-1

CHAPTER IX - SEA LEVEL REPORT

by M. L. Schwartz, Western Washington University . . . . . IX-1

CHAPTER $X$ - HYDROLOGIC EFFECTS OF NATURAL DISRUPTIVE EVENTS

ON NUCLEAR REPOSITORIES

by S. N. Davis, University of Arizona . . . . . . . . X-1

CHAPTER XI - STRUCTURAL GEOLOGY OF THE COLUMBIA PLATEAU AND ENVIRONS

AS RELATED TO THE WASTE ISOLATION SAFETY ASSESSMENT PROGRAM

by H. A. Coombs, University of Washington . . . . . . . XI-1 
CHAPTER XII - EVIDENCE AND THEORY FOR THE PREDICTION OF TECTONIC

ACTIVITY IN THE BASIN AND RANGE PROVINCE OF NEVADA AND UTAH FOR

THE NEXT ONE MILLION YEARS

by E. M. P. Lovejoy, University of Texas . . . . . . . . . XII-1

CHAPTER XIII - PROBABILITY OF EXPECTED CLIMATE STRESSES IN

NORTH AMERICA IN THE NEXT ONE M.Y.

by G. Kuk la, Lamont-Doherty Geological Observatory . . . . . XIII-1

CHAPTER XIV - ASSESSMENT OF TECTONIC HAZARDS TO WASTE

STORAGE IN INTERIOR-BASIN SALT DOMES

by R. Kehle, Turk, Kehle, and Associates . . . . . . . . XIV-1 


\section{INTRODUCTION}

Associated with commercial nuclear power production in the United States is the generation of potentially hazardous radioactive waste products. The Department of Energy (DOE), through the National Waste Terminal Storage (NWTS) Program, is seeking to develop nuclear waste isolation systems in geologic formations. These underground waste isolation systems will preclude contact with the biosphere of waste radionuclides in concentrations which are sufficient to cause deleterious impact on humans or their environments. Comprehensive analyses of specific isolation systems are needed to assess the postclosure expectations of the systems. Assessment of Effectiveness of Geologic Isolation Systems (AEGIS) program has been established for developing the capability of making those analyses.

Among the analyses required for isolation system evaluation is the detailed assessment of the post-closure performance of nuclear waste repositories in geologic formations. This assessment is concerned with aspects of the nuclear program which previously have not been addressed. The nature of the isolation systems (e.g., involving breach scenarios and transport through the geosphere) and the great length of time for which the wastes must be controlled dictate the development, demonstration, and application of nove 1 assessment capabilities. The assessment methodology must be thorough, flexible, objective, and scientifically defensible. Furthermore, the data utilized must be accurate, documented, reproducible, and based on sound scientific principles.

The current scope of the Assessment of Effectiveness of Geologic Isolation systems program is limited to long-term, post-closure analyses. It excludes the consideration of processes that are induced by the presence of the wastes, and it excludes the consideration of nuclear waste isolation in media other than geologic formations. The near-field/near-term aspects of geologic repositories are being considered by ONWI/DOE under separate programs. They will be integrated with the AEGIS methodology for the actual site-specific repository safety analyses. 
The assessment of repository post-closure safety has two basic components:

- identification and analyses of breach scenarios and the pattern of events and processes causing each breach;

- identification and analyses of the environmental consequences of radionuclide transport and interactions subsequent to a repository breach.

The Scenario Methodology Development task is charged with identifying and analyzing breach scenarios and their associated patterns of events and processes.

The Scenario Methodology Development task is concerned with evaluating the geologic system surrounding an underground repository and describing the phenomena which alone or in concert could perturb the system and possibly cause a loss of repository integrity. Output from the Scenario Methodology Development task will establish the boundary conditions of the geology and hydrology surrounding the repository at the time of an identified breach. These bounding conditions will be used as input for the consequence analysis task, which will employ sophisticated hydrological transport models to evaluate the movement of radionuclides through the groundwater system to the biosphere.

The Scenario Methodology Development task has contracted with a number of consultants to obtain expert scientific opinion about the geologic processes which could affect an underground repository. The consultants were asked to specify processes and events which might affect potential repository sites and, if possible, to give rates and probabilities for those phenomena. The consultants have also been involved with the description of the system interactions and synergisms. Description of the repository system is an evolving and continuing process. However, much of the preliminary information derived from the FY-1978 research effort is summarized in this document. Most of the research outlined in this report is continuing under the guidance of the Scenario Methodology Development task. Therefore, many of the discussions are not complete and do not answer all of the questions that need to be asked.

This summary report contains information pertaining to the areas of study listed in Table 1. 
TABLE 1.

\begin{tabular}{|c|c|c|}
\hline Study Area & Consultant & Affiliation \\
\hline Climatology & G. Kuk la & Lamont Doherty Geol. Obs. \\
\hline Geomor pho logy (Southwest) & S. Mara & Stanford Research Inst. \\
\hline \multicolumn{3}{|l|}{ *Geomorphology (Pacific } \\
\hline Northwest) & D. Tubbs & Roger Lowe Assoc., Inc. \\
\hline Glaciology & C. Bull & Ohio State Univ. \\
\hline Hydro logy (Southwest) & S. Davis & Univ. of Arizona \\
\hline Hydrology (Pacific Northwest) & M. Veatch & Shannon and Wilson, Inc. \\
\hline *Meteorites & W. Hartmann & Univ. of Arizona \\
\hline *Sea Level Fluctuations & M. Schwartz & Western Wash. Univ. \\
\hline *Se ismo logy & L. Wight & TERA \\
\hline \multicolumn{3}{|l|}{ Structural Geol. (Pacific } \\
\hline Nor thwest) & H. Coombs & Univ. of Washington \\
\hline Structural Geol. (Southwest) & J. Hills & Univ. of Texas \\
\hline Structural Geol. (Gulf Coast) & R. Kehle & Turk, Kehle and Assoc. \\
\hline \multicolumn{3}{|l|}{ Structural Geol. (Basin and } \\
\hline Range ) & E. Lovejoy & Univ. of Texas \\
\hline Volcanology & B. Crowe & Los Alamos Sci. Labs \\
\hline
\end{tabular}

* Report included in its entirety.

Due to the size of many of the consultant reports, only executive summaries are included in this document. However, some of the reports have been included in the ir entirety; those reports are marked with asterisks in Table 1. Most of the reports not included in their entirety herein will be issued as separate, topical reports.

The results of the FY-1978 consultant studies described in the following chapters are being used as a baseline for continued study. In many cases, the work done by the consultants has caused new questions to be raised. In an attempt to answer these new questions, and to more fully cover the subject areas studied in the FY-1978 effort, the consultant studies are being continued under the direction of the Scenario Methodology Development task. 
Studies conducted during FY-1978 tended to be generic rather than media or site specific. Safety assessment for underground waste repositories cannot be done in a true generic sense. Rates and probabilities of geologic processes and events that may affect the repository system can differ greatly from place to place. A certain phenomenon that would be insignificant at one site or in a particular media may be a very important factor at another site or in another media. Therefore, the consultant studies are being focused on media that are currently under consideration for possible repository siting. The media currently being emphasized are the basalts of the Columbia Plateau, the interior salt domes of the Gulf Coast Region, and the bedded salts of the Southwest.

Many of the results outlined in this report were based on the expert opinion of the individual consultants. These results are subject to change as work continues and the various phenomena are better understood. The Scenario Methodology Development task intends that this summary be used as a point of discussion and reference for geological phenomena and their potential impacts on a nuclear waste repository. 
CHAPTER I

\author{
DISRUPTIVE EVENT ANALYSIS: \\ VOLCANISM AND IGNEOUS INTRUSION
}

B. M. Crowe

Los Alamos Scientific Laboratory

Three basic topics are addressed for the disruptive event analysis: first, the range of disruptive consequences of a radioactive waste repository by volcanic activity; second, the possible reduction of the risk of disruption by volcanic activity through selective siting of a repository; and third, the quantification of the probability of repository disruption by volcanic activity.

In examining these topics, several assumptions are made. The probability of volcanic activity within the eastern United States (east of the Rocky Mountains) is assumed to be extremely low. Actual values can probably not be specified numerically but must be orders of magnitude lower than those for areas west of the Rockies. Another assumption is that a repository site will not be located within the general boundaries of an active volcanic province. An active volcanic province is defined as a region having multiple volcanic centers of Quaternary age (less than $1.8 \times 10^{6} \mathrm{yr}$ ) and including some eruptive activity within the last $10^{5}$ to $5 \times 10^{5}$ years. Avoidance of areas of active volcanism for repository siting should result in a significant reduction in the probability of repository disruption by future volcanic activity.

\title{
POSSIBLE MODES OF DISRUPTION BY VOLCANISM
}

For the first part of the study, the consequences of direct intersection of a repository by magmatic activity are considered. There are two major variables: type of volcanic activity and depth of intersection of a repository by magmatic activity. 
The first major variable is the nature of volcanism. There is a wide range in the character of volcanic eruptions, depending in large part on the composition of the magma. The character of the eruption will strongly control the potential disruption and transport distance of radionuclides.

The depth and geometry of intersection of a repository by magmatic activity strongly controls the degree of disruption (percentage of repository dispersed) and the potential biosphere pathways created. Four general cases are considered:

Case 1: Injection of magma into or through a waste repository at a shallow depth $(<500 \mathrm{~m})$ followed by surface volcanism.

Case 2: Injection of magma into or through a waste repository at depth $(>500 \mathrm{~m})$ followed by surface volcanism.

Case 3: Injection of magma into or through a repository at depth $(>500 \mathrm{~m})$ without surface volcanism (igneous intrusion).

\section{Case 4: Distant volcanism.}

\section{Case 1}

The important boundary condition of Case 1 is that the waste repository is located at a relatively shallow level, so that the vault lies within the zone of near-surface disruption produced by the volcanic activity. The waste is assumed to be directly incorporated and dispersed by the volcanism. Therefore, the percentage of repository disruption will be a function of the nature of the volcanism. Assuming a $10 \mathrm{~km}^{2}$ repository, the percentage of waste dispersed will vary from $100 \%$ for explosive silicic eruptions to as 10 w as $10 \%$ or less for Strombolian (cinder cone) eruptions. Potential transport distances of radionuclides will be controlled by the maximum transport distances of volcanic processes. Furthermore, the rates of volcanic transport of radionuclides to the biosphere following repository intersection can be considered to be instantaneous (in comparison to the lifetime of the repository).

\section{Case 2}

For Case 2, the repository vault is located below the zone of surface disruption. This geometry is realistic only for basaltic volcanism. A 
500 meter-burial depth would place the vault below probable disruption depths for basaltic eruptions. However, burial depths exceeding 4 to 5 kilometers would be required to achieve this geometry for large andesitic centers and most silicic volcanic centers. As in Case 1 , the waste is assumed to be directly incorporated and dispersed by the magma. However, the percentage of inventory disrupted is much less than for Case 1 (for basaltic eruptions) and would probably not exceed $25 \%$ (assuming a $10 \mathrm{~km}^{2}$ repository). Potential transport distances of radionuclides will be controlled by the maximum transport distances of volcanic processes.

Case 3

For Case 3, a repository vault is intersected by magma, but the magma is not erupted to the surface. Case 3 involves intrusive, not extrusive, activity. This case differs greatly from Cases 1 and 2. Pathways to the biosphere are secondary or nonvolcanic, with the possible exception of fluid transport to hot spring or geyser discharge areas. Transport distances are governed by the range of secondary effects such as ground-water or hydrothermal circulation driven by convective heat transfer from the magma body. Lag time (the interval of time between repository intersection and development of primary or secondary release pathways) has a major role in this case.

Case 4

Case 4 includes distant volcanism that does not directly intersect a repository site but may cover the surface overlying the vault with volcanic material (lava flows, pyroclastic flows, tephra, etc.). In this case the effects are entirely secondary and were not examined in detail. Some possible effects include:

- surface drainage disruption with possible changes in erosion rates

- modificatons of recharge-discharge areas of a ground water system

- climate changes resulting from particulate loading of the atmosphere from ash ejected during large explosive eruptions. 
PROJECTION OF FUTURE SITES OF VOLCANISM

The second topic addressed in this study is the possible reduction of risk through selective siting of a repository. Selective siting involves identification of future areas of volcanic activity, based on the present state of knowledge in volcanology.

Volcanism occurs primarily at subduction zones and oceanic rises. Two major settings of subduction zone volcanism are important: island arcs, in which the volcanic chain is constructed on oceanic crust, and continental arcs, in which the volcanic chain overlies continental crust. With respect to the western United States, the Cascade volcanic chain appears to be a continental arc located east of an inferred, east-dipping, buried, and presently aseismic subduction zone off coastal northern California, Oregon and Washington. Numerous geologists have suggested that the Cenozoic record of volcanism with in the Basin and Range Province may reflect the former presence of a subduction zone adjacent to the coast of the western United States. Volcanic rocks are also found at oceanic rises. Ocean rises are linear ridges of plate divergence (boundaries along which plates separate) and are generally characterized by active basaltic volcanism. With respect to the western United States, volcanism within the Salton Trough of southernmost California may reflect the onland projection of the East Pacific Rise.

Distinct concentrations of volcanic rock within zones or volcanic provinces are noted. These volcanic provinces can qualitatively be viewed as high risk zones and can thereby be avoided for siting of a radioactive waste repository. High risk zones must additionally be evaluated with respect to future migration or expansion of areas of volcanism within the next 1 m.y. The degree of geologic detail required to extrapolate future volcanism from past volcanic activity is beyond the scope of this paper and is best directed at a site specific level. However, to illustrate the application of possible techniques to volcanic projections, three general areas are described in the following sections. 
Salton Trough

The Mexicali-Imperial Valley, located in southernmost California and Mexico, is a broad structural trough (commonly referred to as the Salton Trough) that appears to be the onland northern extension of the Gulf of California. The Salton Trough is a zone of high heat flow and Quaternary volcanism. Tectonic studies of the trough indicate that it is lengthening to the northwest at a rate on the order of $5 \mathrm{~cm} / \mathrm{yr}$. Consequent with the northwestward lengthening of the trough, it is likely that there will be continued and perhaps significant northwestward migration of volcanism within the area during the next 1 m.y.

High Cascade Range

The High Cascade Range is formed by a chain of large andesitic volcanic centers and associated basaltic volcanic centers. It extends from northern California into British Columbia. The presence of this probable continental volcanic arc is commonly attributed to the presence of an inferred, eastdipping aseismic subduction zone concealed beneath marine sediments off the coast of the Pacific Northwest. Based upon this assumption, the Cascade chain should continue to exhibit active volcanism in the future. The magnitude of the activity is difficult to predict, however, due to the lack of geologic information concerning the behavior of subduction related volcanism as the rise approaches the continent.

Wasatch Front - Basin Range Volcanism

Late Cenozoic alkalic basalts are found along the east boundary of the Basin and Range Province in northwesternmost Arizona and southwesternmost Utah. Based on an analysis of $\mathrm{K}$-Ar dates, an apparent eastward migration of basaltic volcanism at the rate of approximately $1 \mathrm{~cm} / \mathrm{yr}$ is suggested. Projection of these patterns, which are recorded for rocks ranging in age from $7.0 \mathrm{~m} . \mathrm{y}$. to less than $1.0 \mathrm{~m} . \mathrm{y}$. , suggests that basaltic volcanism may encroach in an eastward direction onto the Colorado Plateau within the next 1 m.y. 
Regional Generalizatons

- Basalt is widely distributed and is the most abundant magma composition in the geologic record. Consequently, the most frequent eruption types are likely to be Strombolian and/or Phreatomagmatic (cinder cones-maar volcanoes).

- There is a strong correlation between the type of geologic province and the nature of the associated volcanism. For example, continental arcs are generally characterized by the development of andesitic cones, and oceanic rises by volcanism.

- Basaltic volcanism can occur within areas where there would be little or no compelling geologic evidence to expect volcanism.

- During the last $2 \mathrm{~m} . \mathrm{y}$. there were at least seven major explosive silicic eruptions within the western United States, including Crater Lake caldera $(6,600$ years), Yellowstone caldera (three eruptions, 2.0, 1.2 and 0.6 m.y.), Valles caldera (two eruptions, 1.4 and 1.1 m.y.) and Long Valley caldera $(0.7 \mathrm{m.y.})$. As much as several hundred $\mathrm{km}^{3}$ of magma were extruded during some of these eruptions. Consequently, the effects of similar future eruptions on climate and/or surface erosion rates could be substantial. Based on this past record, it is likely that the western United States will experience one and possibly several eruptions of this type during the next $1 \mathrm{~m} . \mathrm{y}$.

\section{PROBABILITY CALCULATIONS}

The third and final topic to be addressed is the quantification of the probability of repository disruption by volcanic activity.

In the geological literature, some attempts have been made to calculate the probability of volcanic activity. The following numbers have little meaning, but the procedures are of interest. Consider volcanic probabilities for the WIPP (Waste Isolation Pilot Plant) in southeastern New Mexico. The WIPP site is located within the Delaware Basin, an area with no preserved record of volcanism since the end of Permian time (approximately $200 \times 10^{6}$ years ago). 
One event in $200 \times 10^{6}$ years equals $5.0 \times 10^{-9}$ events/year. Using this rate of volcanism, and assuming a $10 \mathrm{~km}^{2}$ waste repository, the Delaware Basin area of $3.1 \times 10^{4} \mathrm{~km}^{2}$, and a volcanic effect zone of $50.3 \mathrm{~km}^{2}$, the resulting probability, $P$, of volcanic activity is:

$$
\begin{aligned}
P & =\left(5.0 \times 10^{-9} / \mathrm{yr}\right)\left(50.3 \mathrm{~km}^{2} / 3.10 \times 10^{4} \mathrm{~km}^{2}\right) \\
& =8.1 \times 10^{-12} / \mathrm{yr} .
\end{aligned}
$$

The major limitation of this calculation is the logic of using a rate of volcanism of 1 event in $200 \mathrm{million}$ years. Furthermore, the size of the disruptive zone is somewhat large, though not significant in the calculation.

For this study, "determination" of probability calculations has been attempted for several selected areas. The derived numbers are of little value except that they are established for areas of active volcanism. The probability of volcanic activity for nonvolcanic areas has to be substantially less. The emphasis in this section is not on the actual numbers but on the calculation procedures.

\section{High Cascade Range}

Geologic studies of large composite cones within the Cascade Range suggest an average eruption rate of one eruption per century for the volcanic chain. Geophysical data for a representative composite cone suggest the presence of a magma chamber at a depth of 1.5 to $4 \mathrm{~km}$ with an average radius (high temperature part) of $3.6 \mathrm{~km}$. Such dimensions yield a disruption zone of about $22 \mathrm{~km}^{2}$. This number can be expanded by considering various geometric configurations of intersection of a repository by the disruption zone, but maximum variation is on the order of a factor of three.

Using a rate of volcanism of $10^{-2}$ events/year, a $66 \mathrm{~km}^{2}$ disruptive zone, and an area of $1.1 \times 10^{5} \mathrm{~km}^{2}$ for the cascades, the probability, $\mathrm{P}$, of volcanic activity is:

$$
\begin{aligned}
P & =\left(10^{-2} / \mathrm{yr}\right)\left(66 \mathrm{~km}^{2} / 1.1 \times 10^{5} \mathrm{~km}^{2}\right) \\
& =6.0 \times 10^{-6} / \mathrm{yr} .
\end{aligned}
$$




\section{Snake River Plain}

The Snake River Plain is an elongate valley in southern Idaho characterized by extensive Quaternary volcanism. A $750 \mathrm{~km}^{2}$ area of the Snake River Plain has been studied in detail, resulting in establishment of a recurrence interval for volcanism of one eruption per 10,000 yrs.

Two values are used for the disruption area. The first value is the volcanic effect zone of $50.3 \mathrm{~km}^{2}$, and the second is a more realistic value assuming deep burial of waste $(>500 \mathrm{~m})$. Geologic studies have shown that basaltic cones are generally fed by relatively narrow dikes ( $<10 \mathrm{~m}$ wide) and consequently, disruption at depth from a $10 \mathrm{~m}$ wide feeder dike is considered to be approximately $2.1 \mathrm{~km}^{2}$ (assuming a 10 meter wide dike with an additional 100 meter disruption zone adjacent to each margin and a lateral extent equal to the maximum repository width or $10 \mathrm{~km}$ ). Thus, for each case the probability of volcanic activity, $P$, is:

$$
\begin{aligned}
P & =\left(1.0 \times 10^{-4} / \mathrm{yr}\right)\left(50.3 \mathrm{~km}^{2} / 750 \mathrm{~km}^{2}\right) \text { CASE ONE: Large Disruption Zone } \\
& =6.7 \times 10^{-6} / \mathrm{yr} ; \\
P & =\left(1.0 \times 10^{-4} / \mathrm{yr}\right)\left(2.1 \mathrm{~km}^{2} / 750 \mathrm{~km}^{2}\right) \text { CASE TWO: Smal1 Disruption Zone } \\
& =2.3 \times 10^{-7} / \mathrm{yr} .
\end{aligned}
$$

As a second approach, a vent count of Holocene $(<10,000$ yrs old) volcanic centers for a selected $2.6 \times 10^{4} \mathrm{~km}^{2}$ area was completed. Eighty-five vents were counted, yielding a rate of:

$$
8.5 \times 10^{-3} \text { events per year }
$$

assuming that each vent can be counted as one event (clearly invalid). Making the same disruption zone assumptions as were made in the previous section yields two cases:

CASE ONE: Large Disruption Zone

$$
\begin{aligned}
P & =\left(8.5 \times 10^{-3} / \mathrm{yr}\right)\left(50.3 \mathrm{~km}^{2} / 2.6 \times 10^{4} \mathrm{~km}^{2}\right) \\
& =1.6 \times 10^{-5} / \mathrm{yr} ;
\end{aligned}
$$


CASE TWO: Small Disruption Zone

$$
\begin{aligned}
P & =\left(8.5 \times 10^{-3} / \mathrm{yr}\right)\left(2.1 \mathrm{~km}^{2} / 2.6 \times 10^{4} \mathrm{~km}^{2}\right) \\
& =6.7 \times 10^{-7} / \mathrm{yr} .
\end{aligned}
$$

As a final approach the dike surface area for 85 events in 10,000 years was calculated. Making the same areal assumptions for the dike area and disruption zone as were made for the previous section $\left(2.1 \mathrm{~km}^{2}\right)$ yields:

$$
\begin{aligned}
& =(85 \text { events })\left(2.1 \mathrm{~km}^{2}\right) \text { per } 10,000 \text { yrs } \\
& =1.8 \times 10^{-2} \mathrm{~km}^{2} \text { events per year. } \\
P & =\left(1.8 \times 10^{-2}\right)\left(10 \mathrm{~km}^{2} / 2.6 \times 10^{4} \mathrm{~km}^{2}\right) \\
& =6.9 \times 10^{-6} / \mathrm{yr} .
\end{aligned}
$$




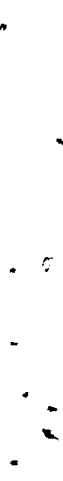

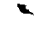

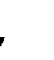

$\cdot$

.

-

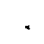

$-$

$\checkmark$ 
CHAPTER II

PACIFIC NORTHWEST GEOMORPHOLOGY AND HYDROLOGY: RATES AND PROBABILITIES OF SELECTED PROCESSES AND EVENTS

D. W. Tubbs

University of Kansas

\section{INTRODUCTION}

This report presents the results of one of the geomorphological and hydrological studies that have been conducted for the release scenario analys is of the Waste Isolation Safety Assessment Program (WISAP). Three general topics are considered: (1) determination of rates of denudation, (2) estimation of the probability of flooding due to each of several causes, and (3) evaluation of other surface processes that should be considered in the release scenario analysis. Because other project consultants were studying factors pertaining to meteorite impact, volcanology, climatology, glaciology, coastal processes and sea-level fluctuations, the third general topic was ultimately narrowed to the possible effects of landsliding.

Estimates of rates and probabilities given in this report are based on methods found in the literature for various studies throughout the world. No attempt has been made to develop new techniques or predictive theories. Rates of erosion are expressed in this report as centimeters per 100 years, except that the original units are retained in figures taken from other sources. Probabilities are also expressed per 100 years. The 100 year time period was chosen to correspond to the time increment that will initially be utilized in the computer model incorporating the results of these studies.

\section{DENUDATION}

Various authors have estimated erosion rates from sediment loads for individual drainage basins, selected regions, and entire continents. These 
estimates have been most commonly based on measurements of the suspended sediment carried by the rivers. Sedimentation rates in reservoirs and chemical analyses of river water samples have also been used. In particular areas, tombstone erosion rates, bristlecone pine root exposures, archaeological evidence, paleotopographic reconstructions, studies of waterfall retreat, and other techniques have been utilized to estimate erosion rates.

The total sediment load carried by a river is the sum of its suspended load, bed load and dissolved load. The bulk of the available literature concentrates on the suspended sediment fraction, because it is generally the most significant and because bed load is generally difficult to measure. A bed load equal to $10 \%$ of the suspended sediment fraction is commonly assumed, but in braided rivers the bed load may exceed $50 \%$ of the total load (Gilluly, 1955; Dury, 1969). Dissolved load generally constitutes less than $10 \%$ of the total load estimates in arid regions, but it increases to nearly $40 \%$ of the total load in more humid areas (Leopold et al., 1964). Langbein and Dawdy report that above an annual precipitation of about 25 inches, additional precipitation does not appear to produce any further increase in dissolved load (Leopold et al., 1964).

The accuracy of estimates of denudation rates based on sediment sampling techniques depends in part on the length of the sampling period; the longer the sampling period the more reliable the data. Judson and Ritter (1964) have shown that the annual sediment load of rivers can vary by a factor of five between successive years. Thus, estimates based on only one year of data can be in error by more than $50 \%$.

Several examples of denudation rates based on sediment load measurements are given in the literature. Stoddart (1971) cites a denudation rate for North and Central America (combined) that is equivalent to $0.39 \mathrm{~cm} / 100$ years, and Judson (1968) gives a figure equivalent to $0.30 \mathrm{~cm} / 100$ years for the United States. Within the Pacific Northwest, Judson and Ritter (1964) cite a denudation rate equivalent to $0.38 \mathrm{~cm} / 100$ years for the Columbia River Basin upstream from Pasco, Washington. Unfortunately, this last estimate is based on only two years of incomplete records (Ritter, 1967). 
Many predictions of denudation rates are based on empirically derived curves relating sediment yields of streams to drainage basin characteristics. Derbyshire (1976) summarized some of the independent variables that have been used in such empirical relationships. Two empirical relationships are shown as Figures II -1 and II-2.

Figure II-1, adapted from Carson and Kirkby (1972), depicts a rough correlation between denudation rates and mean basin elevation, and also gives some indication of the variance of that relationship. For a drainage basin tributary to the Columbia River in the Pasco Basin, having a mean basin elevation of approximately 200 meters, Figure II-1 indicates a suspended load denudation rate of about $0.2 \mathrm{~cm} / 100$ years. Under the arid conditions of the Pasco Basin, dissolved load would probably be about $10 \%$ and bed load would probably be more than $10 \%$ of the total load. Adjustments for these two factors would result in a total denudation rate of approximately $0.25 \mathrm{~cm} / 100$ years. It is notable that Figure II-1 includes mainly large river basins, and that the small basins in Wyoming, Oklahoma and Texas have denudation rates about twice that of the larger basins shown. This situation is probably due to the higher relief ratios that are possible in small basins, and it suggests that a small drainage basin tributary to the Columbia River in the Pasco Basin might have a denudation rate of approximately $0.5 \mathrm{~cm} / 100$ years.

Figure II-2, adapted from Schumm (1965), shows a relationship between mean annual precipitation, mean annual temperature, and the resulting mean annual sediment yield. Under the arid conditions of the Pasco Basin (a mean annual temperature of $53.6^{\circ} \mathrm{F}$ and a mean annual precipitation of 7.49 inches as measured at Kennewick - see Figure II-3) the family of curves shown in Figure II-2 suggests a mean annual sediment yield of about 350 tons per square mile, which is equivalent to a denudation rate of approximately $0.45 \mathrm{~cm} / 100$ years. Figure II-1, however, excludes dissolved load; assuming a dissolved load of about $10 \%$ of the total load would result in a denudation rate of approximately $0.5 \mathrm{~cm} / 100$ years. 


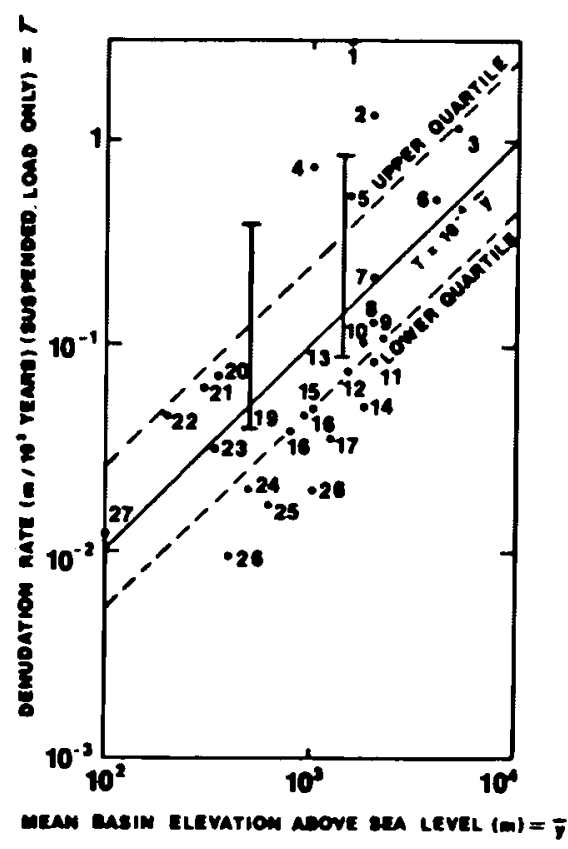

FIGURE II-1. Suspended Solids Denudation Rate as a Function of Elevation (adapted from Carson and Kirkby, 1972)

1. Lo (China)

2. Yellow or Hwang (China)

3. Kosi (India and Nepal)

4. Ganges (India)

5. Red or Yuan (North Vietnam and China)

6. Brahmaputra (East Pakistan and Tibet)

7. Indus (West Pakistan)

8. Yangtse (China)

9. Colorado (U.S.A.)

10. Mekong (South-East Asia and China)

11. Rio Grande (U.S.A. and Mexico)

12. Missouri (U.S.A.)

13. Small Basins in East Wyoming (U.S.A.)

14. Salt (U.S.A.)

15. Red (U.S.A.)

16. Mississippi (U.S.A.)
Key to Rivers Plotted:

17. Cheyenne (U.S.A.)

18. Tennessee (U.S.A.)

19. Small Basins in OKlahoma and Texas (U.S.A.)

20. Roanoke, Virginia (U.S.A.)

21. Santee, North Carolina (U.S.A.)

22. Savannah, Georgia (U.S.A.)

23. Amazon (South America)

24. Nile (North-East Africa)

25. Susquehanna, Pennsyivania (U.S.A.)

26. Brazos, Texas (U.S.A.)

27. Pear1, Mississippi (U.S.A.)

28. Potomac, Virginia and Maryl and (U.S.A.) 


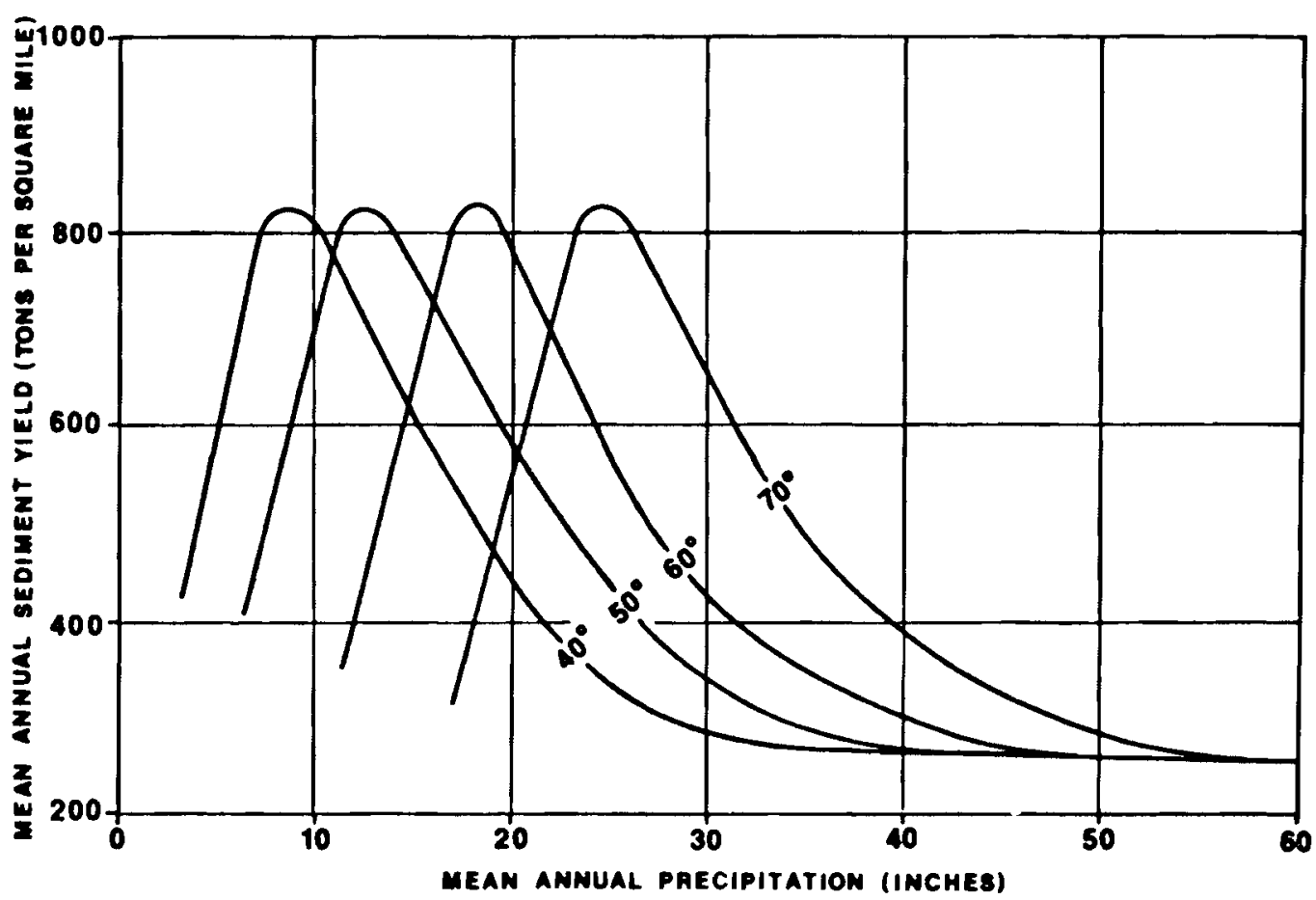

FIGURE II-2. Climate and Sediment Yield (adapted from Schumm, 1965)

Figure II-2 also suggests the direction in which denudation rates would change during glacial episodes. Both lower temperatures and higher precipitation would tend to increase the denudation rate in the Pasco Basin. A decrease in temperature of about $7^{\circ} \mathrm{F}$ accompanied by a slight increase in precipitation would roughly double the denudation rate.

Locally greater erosion rates can be expected where the Columbia River crosses a growing anticline, due to either antecedence or superposition. Judging from the relatively uniform gradient of the Columbia River, the rate of river channel erosion in such instances appears to approximately equal the rate of anticlinal uplift. Newcomb (1958) believed that the Ringold Formation, which he ascribed to the middle to late Pleistocene, was deposited contemporaneously with the uplift of the Horse Heaven Ridge at Wallula Gap. Since the original basalt rim at Wallula Gap is now at an elevation of 1,400 feet, there must have been approximately 1,100 feet of channel erosion at Wallula Gap within roughly the past $1,000,000$ years, yielding a mean erosion rate of 


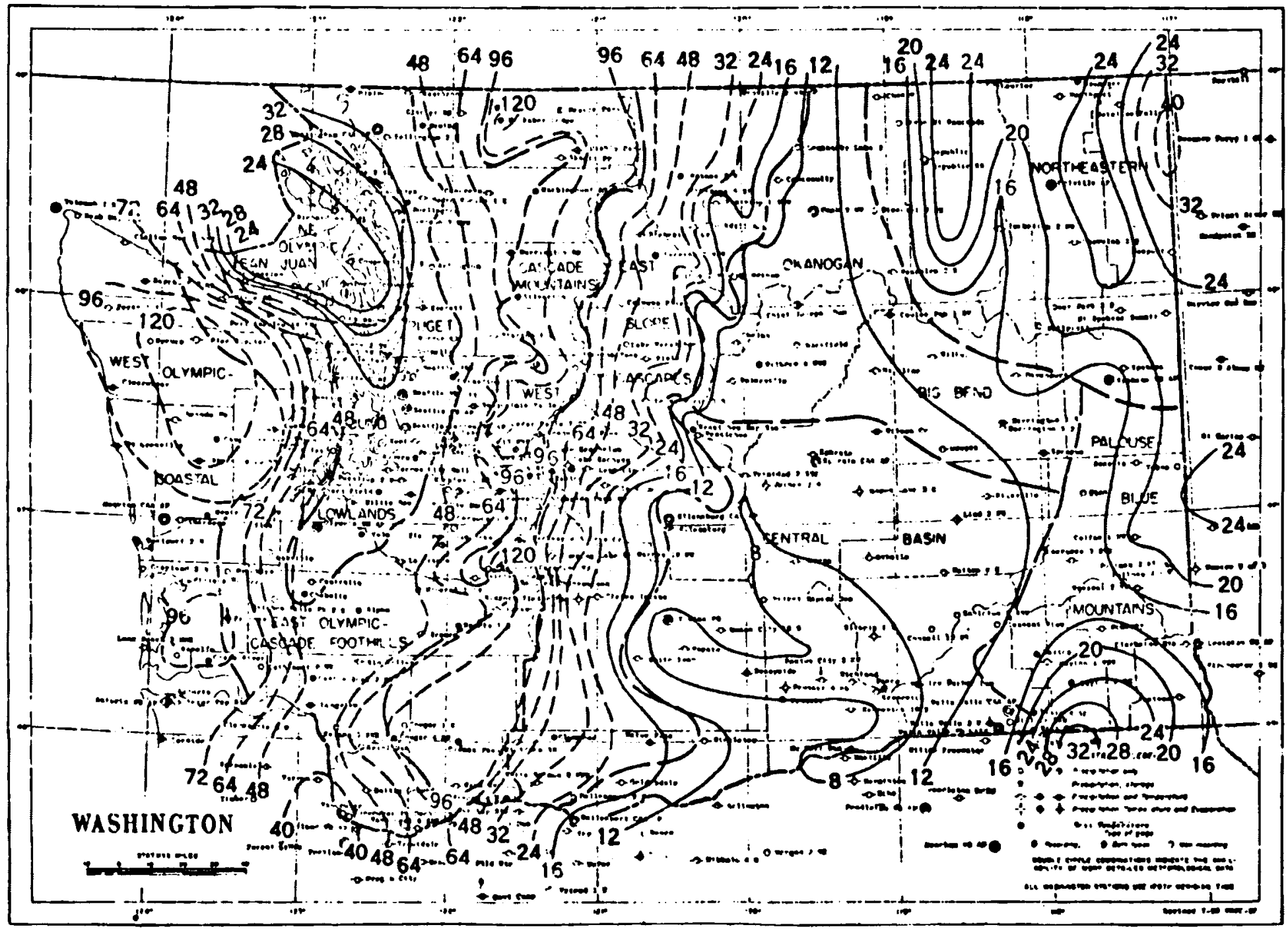

FIGURE II-3. Mean Annual Precipitation in Inches (From U.S. Weather Bureau, 1965) 
$3.35 \mathrm{~cm} / 100$ years. Unpublished studies by $H$. A. Coombs indicate that uplift occurred at about the same rate during the growth of the Saddle Mountains anticline; similar rates of channel erosion are therefore likely to have prevailed at Sentine.l Gap. Newcomb et al. (1972, p. 24) noted that "the Gable Butte-Gable Mountain ridge in places has been stripped of several hundred feet of rock by the Columbia River during post-Ringold time." This statement is consistent with the rate cited above.

$\underline{\text { FLOODS }}$

Flooding in the area of the Columbia River Plateau due to three possible mechanisms was considered as part of this study: 1) flooding caused by precipitation and snow me1t, 2) flooding caused by a hypothetical catastrophic failure of Grand Coulee Dam, and 3) flooding caused by glacial ice dam failures.

Flood-frequency analyses were conducted for the Columbia River on the basis of streamflow records available in various U.S. Geological Survey Water Supply papers. Streamflow data used in the analysis of floods on the Columbia River were taken from records at Trinidad, Washington, from 1913-1960 and from just below Priest Rapids Dam from 1960-1970. Because only a minor change in drainage area occurs between these two stations, and because almost all of the streamflow during large floods can be attributed to snow melt in the upper reaches of the basin, no adjustment was made to the data in response to the change in gaging station location.

Analyses were conducted assuming log-normal, log-Pearson Type III with non-zero skewness and Gumbel extreme value frequency distributions. The Gumbel distributions were determined both using the regular Gumbel methodology and using Chow's (1964) method of adjusting the frequency factor to account for the number of years of records available. The Gumbel distribution is favored by the U.S. Geological Survey, but the log-Pearson Type III distribution is considered standard procedure by the U.S. Water Resources Council. 
The Columbia River Basin has hundreds of flood-control projects ranging from smal1 levees to major dams (U.S. Army Corps of Engineers, 1950b). For this reason two sets of flood frequency analyses were computed. The first considers only the streamflow records prior to 1938 , before the completion of major flood-control structures and prior to the implementation of a floodcontrol plan of operations. The results of these analyses are shown in Figures II-4 and II-5. The second set of analyses includes all years of record, on the assumption that the large floods will be little affected by the flood-control projects. The results of these analyses are shown in Figures II-6 and II-7.

Records of past floods indicate that the largest floods occur in the late spring, following a colder than normal winter and early spring. A rapid rise in temperature accompanied by some precipitation then results in very rapid snow melt. The U.S. Weather Bureau (1945) developed this theory to predict maximum flood-producing conditions for the Columbia River Basin, and the scenario is fairly descriptive of the record 1884 flood. The U.S. Army Corps of Engineers (1950a) used these conditions as a basis for calculating a maximum possible discharge of 1,400,000 cubic feet per second at Priest Rapids Dam, a figure which was used in the design of the spillway. This discharge constitutes the "maximum possible" (or "probable maximum") flood in the vicinity of the Hanford Site. The flood-frequency analyses expressed in Figures 4 through 7 suggest that a flood of this size has a return period of about one million years.

The stage-discharge curve for the Columbia River just below Priest Rapids Dam is shown in Figure 8. A flood of 1,400,000 cubic feet per second would have a flood crest elevation of approximately 460 feet just below Priest Rapids Dam. Pure translation of the flood wave would produce a flood crest elevation of approximately 400 feet at the Hanford townsite. Thus, although structures adjacent to the river would be flooded, the broad upland areas of the Hanford Site would not be affected by even the "maximum possible" flood.

The maximum possible flood caused by precipitation and snow melt, however, is not the greatest flood that can be envisioned in the Pasco Basin. In 19491950, H. A. Kramer conducted a study of the effects upon the Hanford Site from a disaster at Grand Coulee Dam. Kramer concluded that a complete failure of 


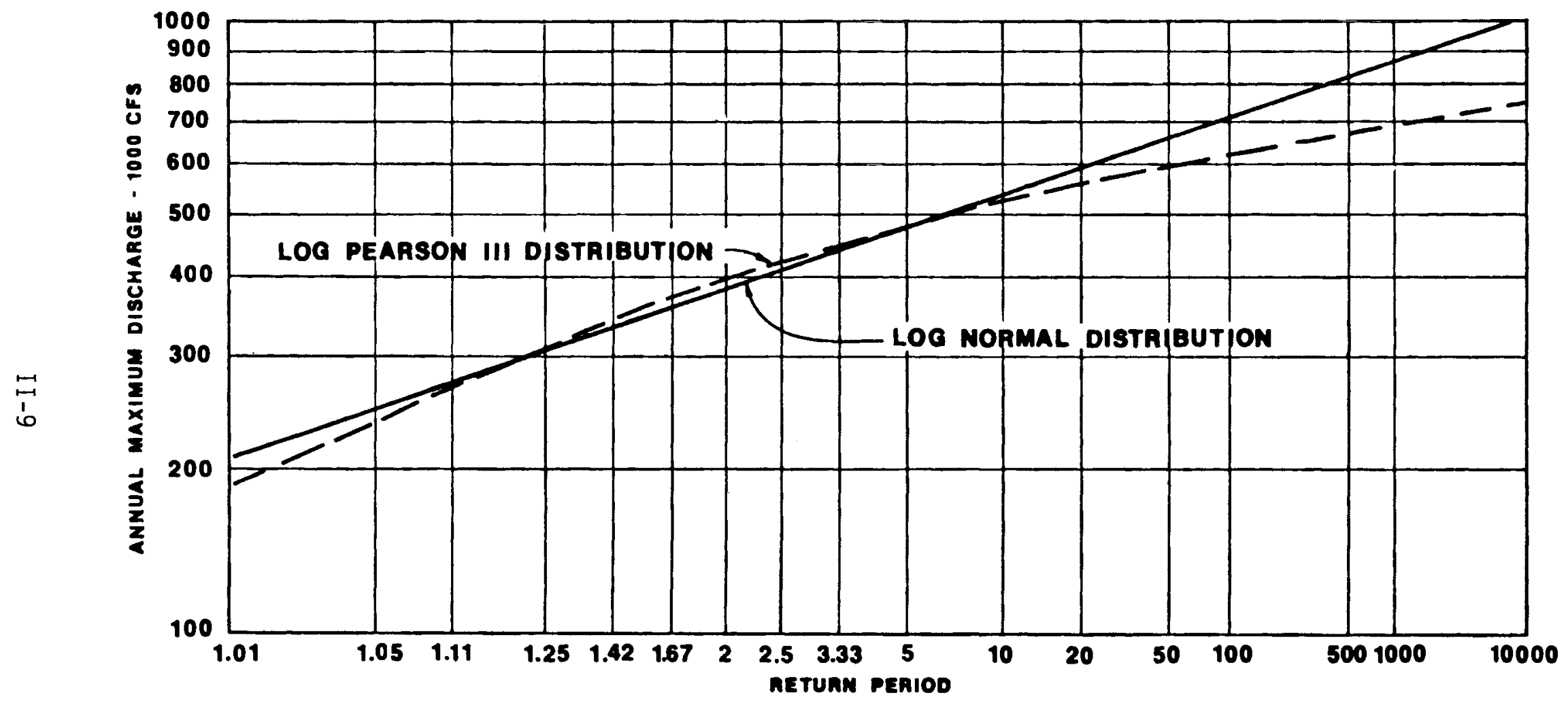

FIGURE II-4. Return Period of Annual Maximum Discharge, Columbia River at Priest Rapids Dam, 1913-1938 (Logarithmic Distributions) 


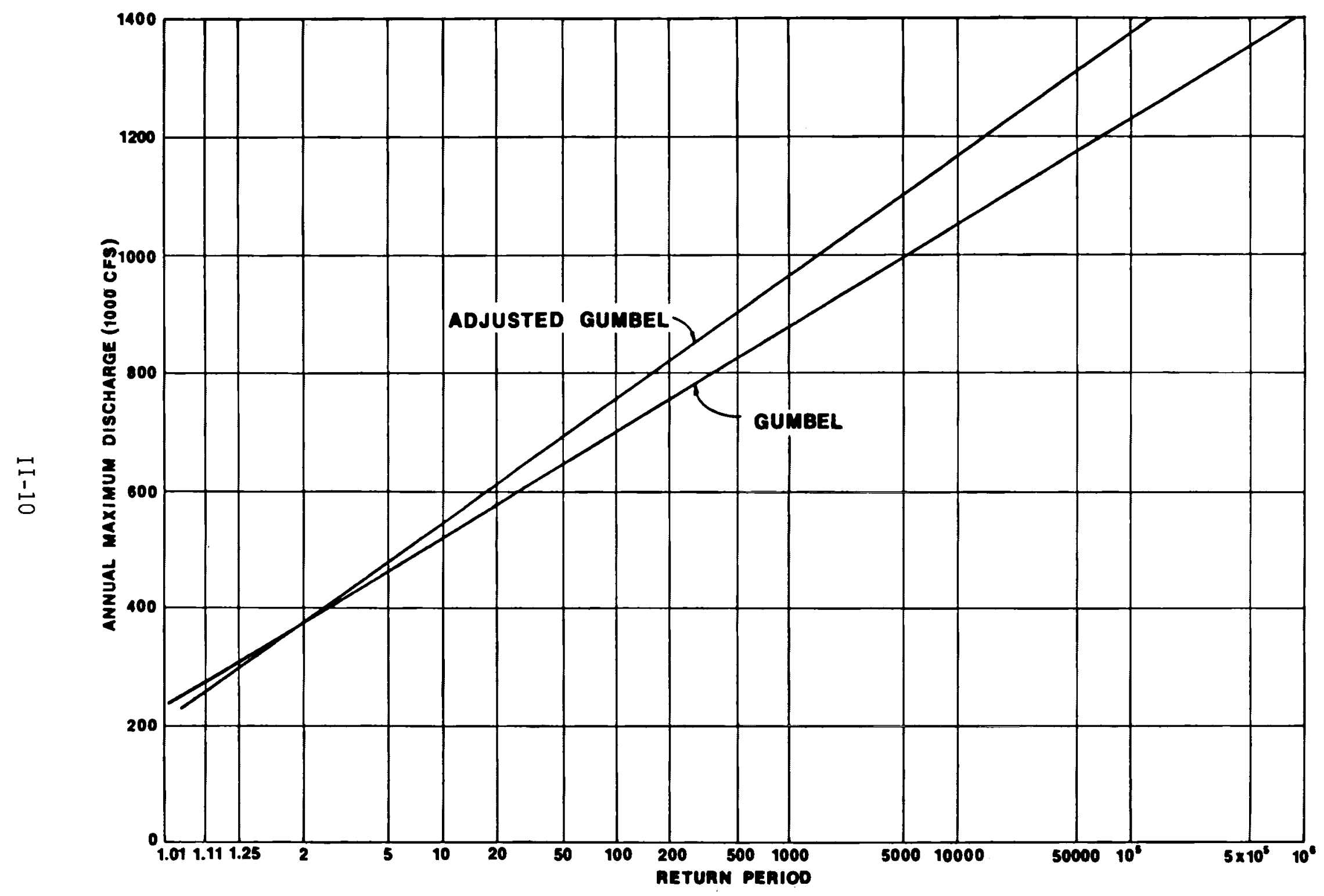

FIGURE II-5. Return Period of Annual Maximum Discharge, Columbia River at Priest Rapids Dam, 1913-1938 (Gumbel Distributions) 


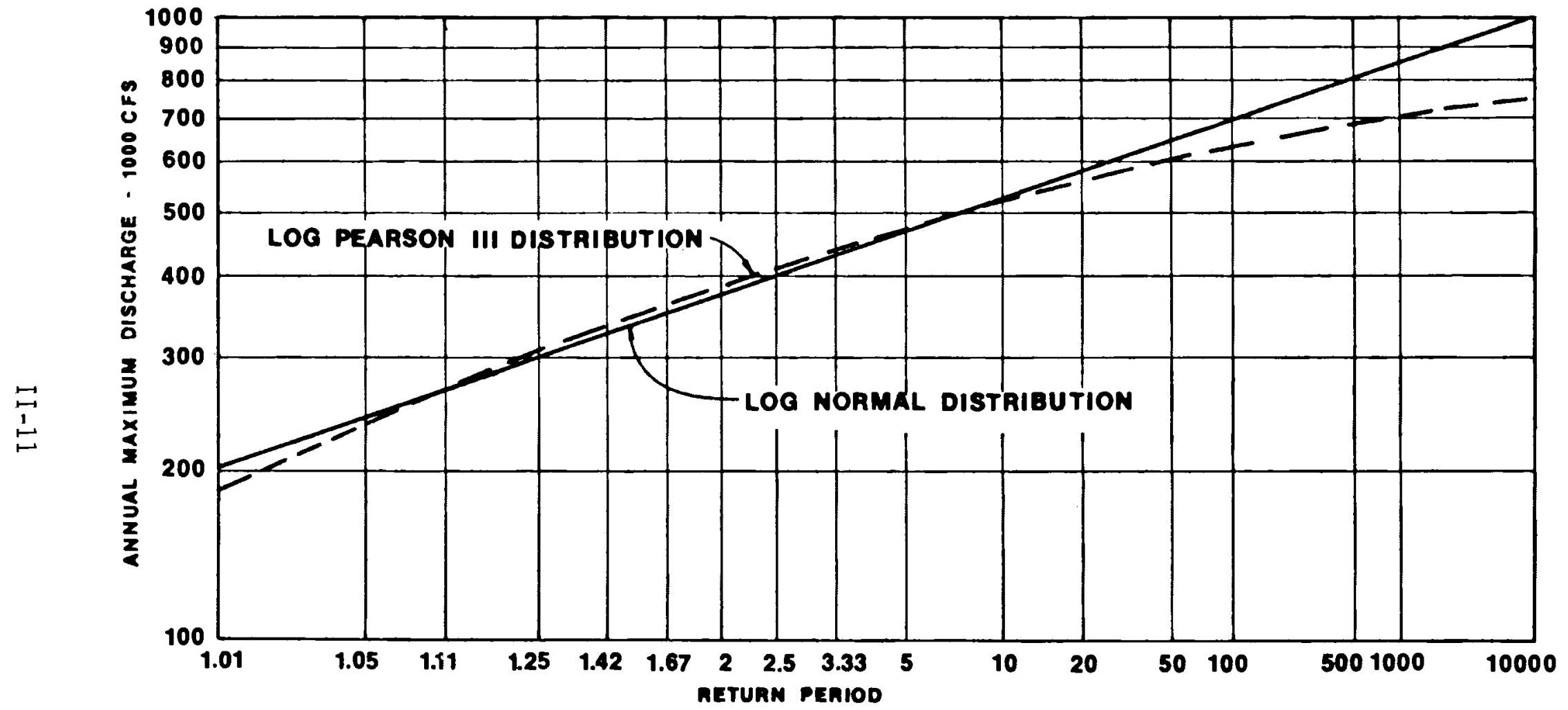

FIGURE II-6. Return Period of Annual Maximum Discharge, Columbia River at Priest Rapids Dam, 1913-1970 (Logarithmic Distributions) 


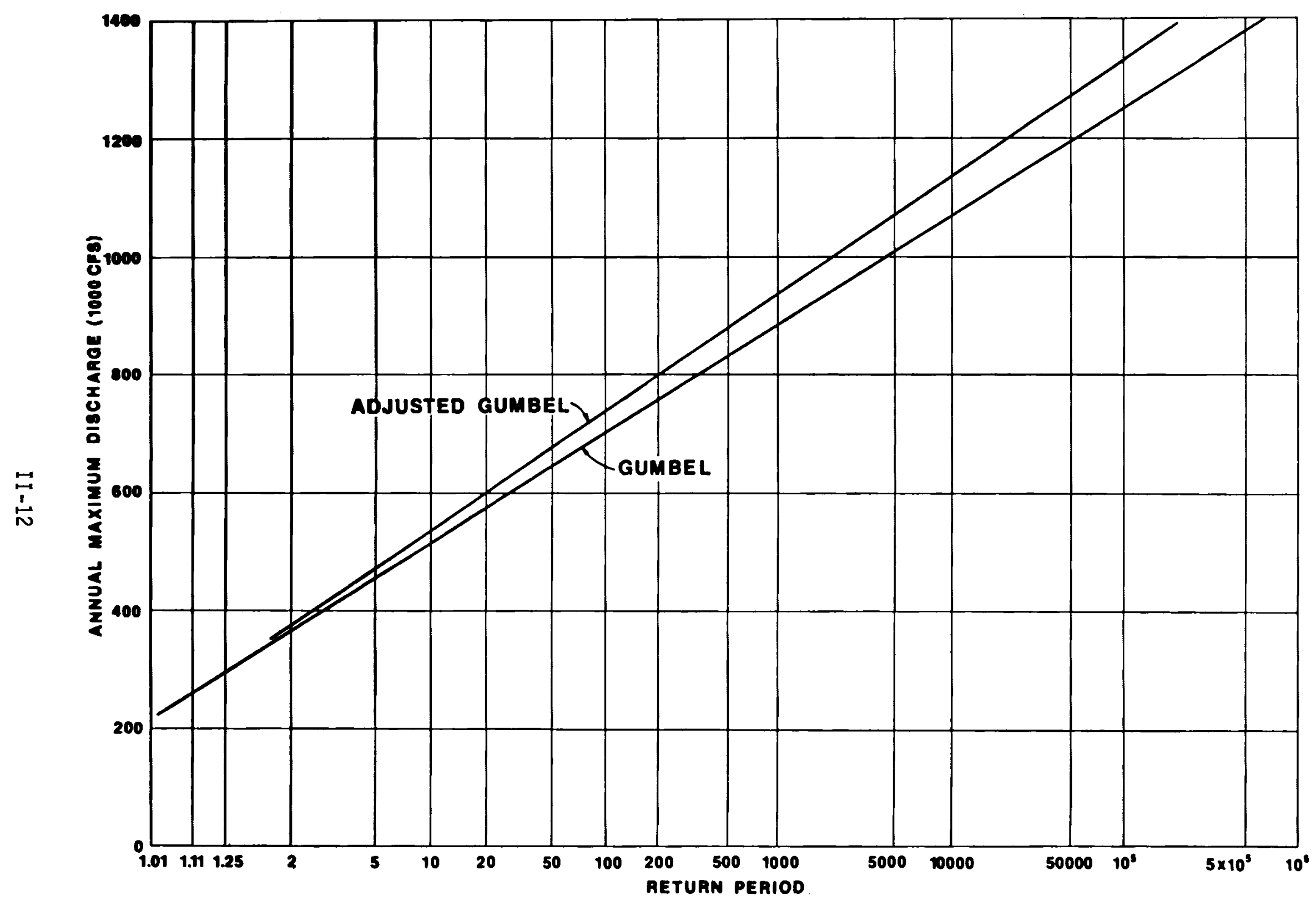

FIGURE II-7. Return Period of Annual Maximum Discharge, Columbia River at Priest Rapids Dam, 1913-1970 (Gumbel Distributions) 


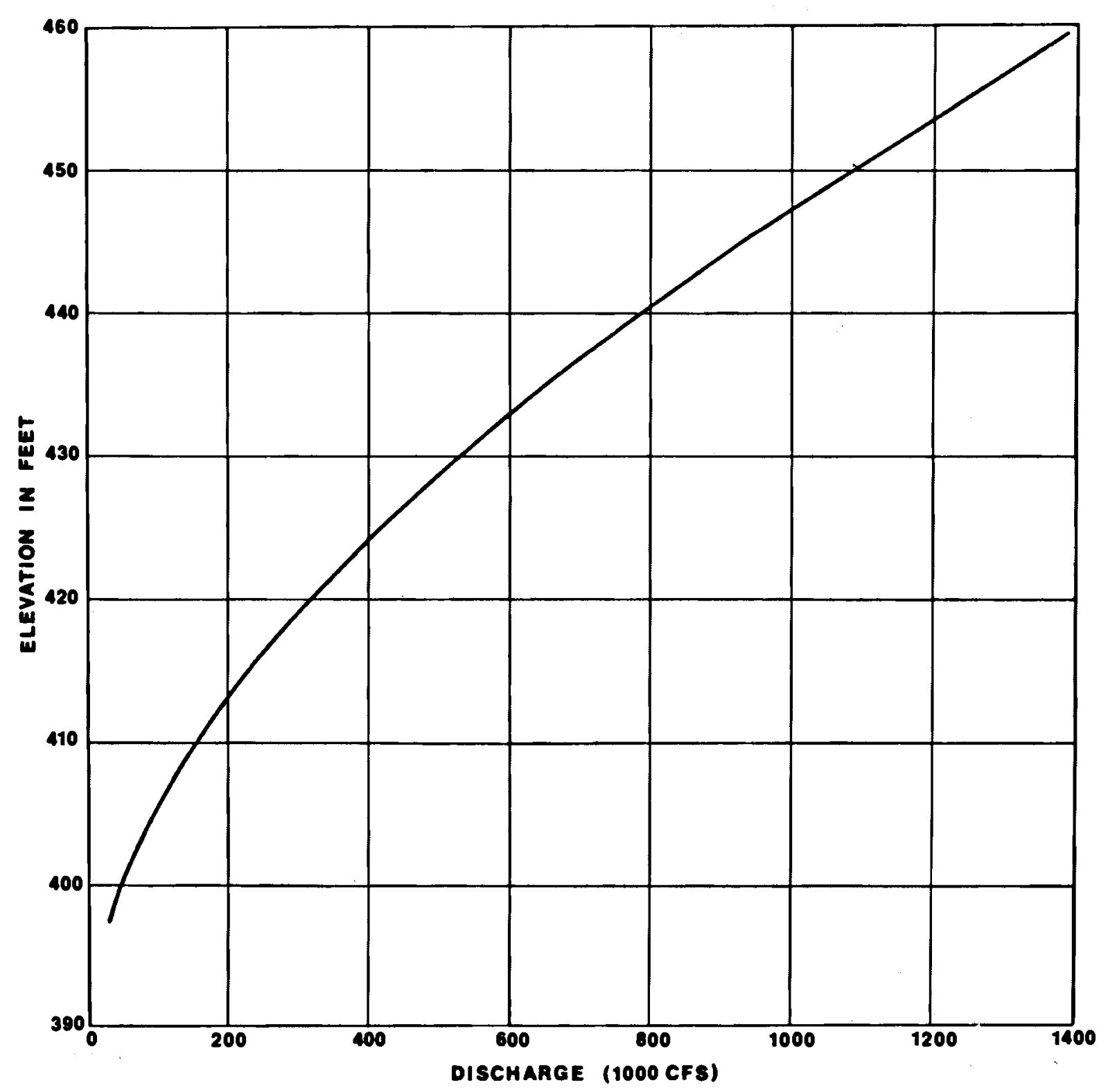

FIGURE II-8. Rating Curve for Columbia River Below Priest Rapids Dam 
the dam would result in a flood discharge at Hanford of 2,627,000 cubic feet per second and a flood crest elevation of 419 feet. The hypothetical flood wave was routed downstream according to the Muskingum method, which relates storage in a reach to inflow and outflow (Viessman et al., 1977), but backcalculations based on Kramer's report indicate that a weighting factor $(x)$ of 0.0 was utilized in the calculations. An " $x$ " value of 0.0 means that the storage in the reach is uniquely a function of outflow, as would be the case in a reservoir. However, the low dams on the Columbia River downstream from Grand Coulee Dam, such as Priest Rapids and Wanapum Dams, would be overwhelmed and would have virtually no effect on a flood of this magnitude.

If a more appropriate average value for " $x$ " of 0.2 is used and the flood wave recalculated, the peak discharge would become approximately $3,700,000$ cubic feet per second and the flood-crest elevation would be roughly 430 to 435 feet at Hanford. Although such a flood would inundate significant areas along the river, especially in the area north of the Gable Butte-Gable Mountain ridge, the broad upland area south of that ridge would still be unaffected.

Even more extreme events have occurred in the Pasco Basin in the geologic past, however, and can be expected to recur in the future. J. Harlen Bretz (1969) has described in detail the effects of catastrophic flooding caused by repeated failures of an ice dam that impounded a 500 cubic mile lake in northwestern Montana. These floods moved across the Columbia Plateau and/or down the Columbia Valley and were hydraulically dammed en route to the Pacific Ocean by the constriction at Wallula Gap.

Although various such floods were probably impounded to somewhat differing depths, a lake elevation of 1,150 feet is generally accepted. This flood would have completely inundated the portions of the Hanford Site north and east of cold Creek. During the lake's maximum stage, the volume of water that was temporarily impounded in the Pasco Basin alone was 175 cubic miles. Flood waters passed through Wallula Gap at a rate of approximately 320,000,000 cubic feet per second (Baker, 1973). Estimates of the lake's duration range from one day to two weeks. 
Bretz (1969, p. 511) believed that there have been at least seven or eight such floods, "corresponding with the nine glacial retreats in northern Montana, Idaho, and eastern Washington." Such flooding did not only occur at the end of major glaciations, but it also occurred during ice-front fluctuations associated with stades and interstades. Bretz implies that at least five or six of these floods have occurred during the past 100,000 years. It thus seems appropriate to assume that the probability of such floods at the close of a glacial interval (i.e. - a stadial) is essentially 1.0.

\section{LANDSLIDES}

Besides their role in regional denudation, landslides can also have various local and indirect effects. Within the area of the Hanford Site, landsliding is primarily related to Columbia River channel erosion and to the uplift of the anticlinal ridges. Most of the landsliding that is related to Columbia River erosion involves the Ringold Formation, but Newcomb et al. (1972) mapped one landslide involving basalt on the steep northern slope of Gable Mountain. Newcomb et al. related landslides along the northeast side of the Rattlesnake Hills to fracturing of the oversteepened 1 imbs of asymmetrical folds during tectonic deformation. Large landslides are also present on the north face of the Rattlesnake Hills. These landslides overlie the upper Pleistocene Touchet Beds as mapped by Newcomb et al., and thus they may be Holocene in age.

The north slope of the Saddle Mountains, just north of the Hanford Site, is oversteepened due to asymmetrical folding, faulting, and undercutting by glacial drainage in Lower Crab Creek. A number of landslides of moderate size are present along this slope, and one large landslide complex exists near Corfu. As interpreted from the 1:62,500 Corfu topographic map, this landslide involved an area of about four square miles (Figure II-9).

The Corfu landslide apparently moved in at least three stages, judging from surface features. The bulk of the landslide, accounting for half or more of the total energy released, must have occurred before the last occupation of Lower Crab Creek by glacial drainage, because the slide material has been 


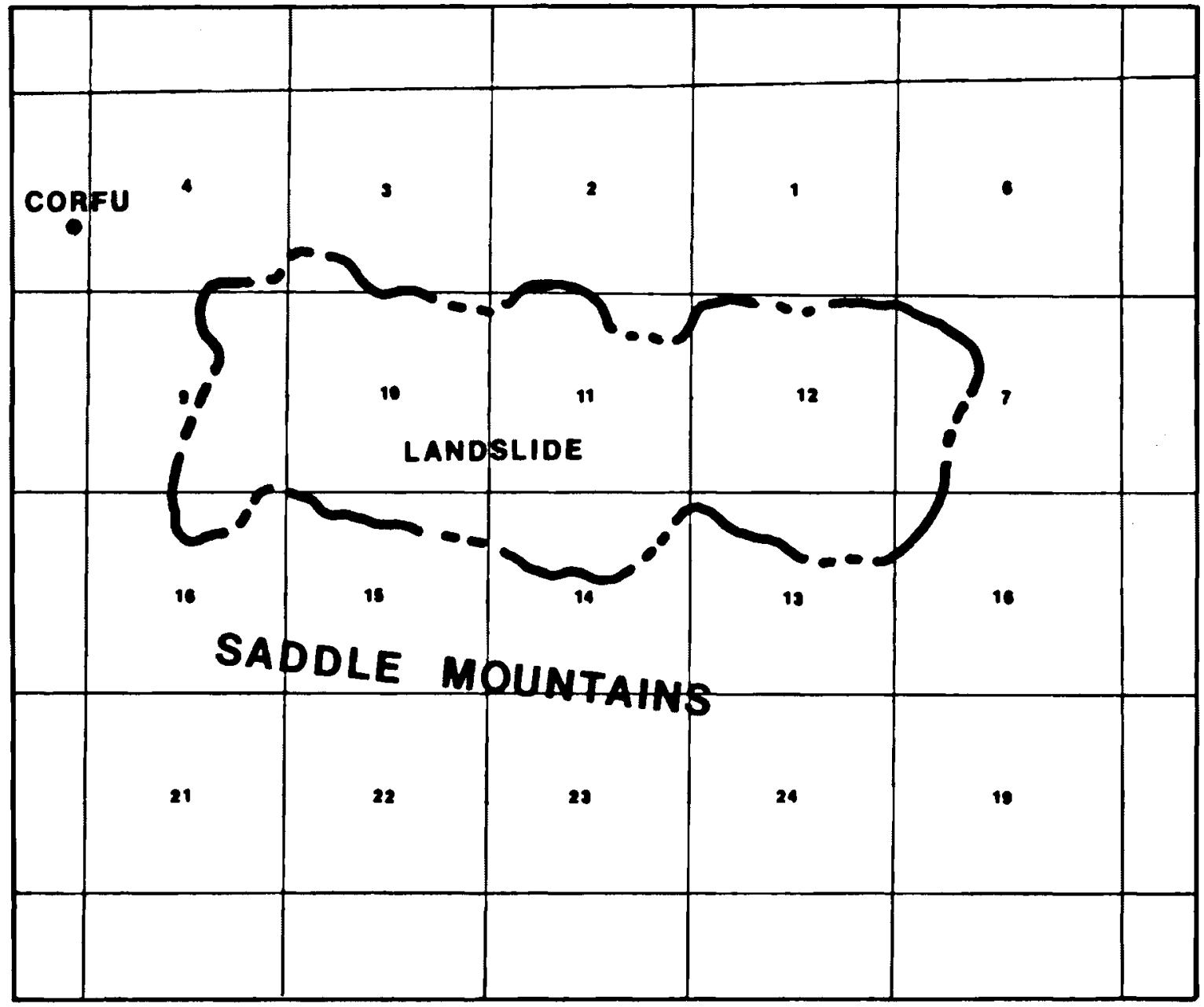

FIGURE II-9. Location and Approximate Extent of Corfu Landslide

removed by the meltwater. This portion of the landslide scar now has the smoothest surface topography of the landslide complex. Subsequent to the last glacial flood in Lower Crab Creek, smaller landslides have occurred on the west and the east sides of the older scar.

Very little is known about the ages of the large bedrock landslides in south central Washington, but in the absence of conclusive data it seems reasonable to expect a landslide on the scale of the Corfu landslide to develop along one of the anticlinal ridges perhaps once every 10,000 years. This is equivalent to a probability of 0.01 during any 100 year period. 
CONCLUSION

Denudation, flooding, and landsliding can be expected to affect the geomorphology and hydrology of the Pacific Northwest. The probability and magnitude of each of these effects are needed as input for the release scenario analysis. This report supplies estimates of rates and probabilities for each of these three factors.

Denudation rates have been given for several cases, ranging from a rate of $0.25 \mathrm{~cm} / 100$ years for a drainage basin tributary to the Columbia River in the Pasco Basin to a previously demonstrated rate of $3.35 \mathrm{~cm} / 100$ years for areas where the Columbia River crosses a growing anticline. The effects of flooding in the area of the Hanford Site are also considered. Values for maximum discharge and flood crest elevation are given for flooding caused by three mechanisms: 1) flooding from precipitation and snow melt, 2) flooding caused by a hypothetical catastrophic failure of Grand Coulee Dam, and 3) flooding from glacial ice dam failures. Flooding caused by the first two mechanisms might result in a flood crest elevation at Hanford on the order of about 400 feet, but flooding caused by glacial ice dam failure might produce a flood crest elevation as high as 1,150 feet.

Landsliding effects were discussed using the Corfu landslide as a reference. A landslide on the scale of the Corfu landslide can perhaps be expected to occur once in every 10,000 years, yielding a probability of $0.01 / 100$ years.

\section{REFERENCES}

Baker, V. R. 1973. Paleohydrology and Sedimentology of Lake Missoula Flooding in Eastern Washington. Geol. Soc. of Amer., Spec. Paper 144. Bretz, J. H. 1969. "The Lake Missoula Floods and the Channeled Scabland." Jour. Geol. 77:505.

Carson, M. A., and M. J. Kirkby. 1972. Hills lope Form and Process. Cambridge Univ. Press, Cambridge, MA.

Chow, V. T. 1964. Handbook of Applied Hydrology. McGraw-Hill Co., NY. 
Derbyshire, E. 1976. Geomorphology and Climate. John Wiley and Sons, London, England.

Dury, G. H. 1969. Perspectives on Geomorphic Processes. Assoc. of Amer. Geographers Res., Paper No. 3.

Gilluly, J. 1955. Geologic Contrasts between Continents and Ocean Basins. Geol. Soc. Amer., Spec. Paper 62.

Gutenberg, B. and C. F. Richter. 1956. 1970. Causes of Earthquakes. Earthquake Engineering, Prentice Hall, NJ.

Judson, S. 1968. "Erosion of the Land, or What's Happening to our Continents?" Amer. Scientist. 56:356.

Judson, S., and D. F. Ritter. 1964. "Rates of Regional Denudation in the United States." Jour. Geophys. Res. 69:3395.

Kramer, H. A. 1950. A Study of the Effects of a Disaster at Grand Coulee Dam upon the Hanford Works. Genera1 Electric Document No. HW-15882.

Leopold, L. B., M. G. Wolman and J. P. Miller. 1964. Fluvial Processes in Geomorphology. W. H. Freeman, San Francisco, CA.

Newcomb, R. C. 1958. "Ringold Formation of Pleistocene Age in Type Locality, the White Bluffs, Washington." Amer. Jour. Science. 256:328.

Newcomb, R. C., J. R. Strand and F. J. Frank. 1972. Geology and Groundwater Characteristics of the Hanford Reservation of the U.S. Atomic Energy Commission, Washington. U.S. Geol. Survey Prof., Paper 717.

Ritter, D. F. 1967. "Rates of Denudation." Jour. Geol. Education 15(4).

Schumm, S. A. 1965. "Quaternary Paleohydrology". in The Quaternary of the United States, eds. Wright and Frey, Princeton Univ. Press, Princeton, NJ.

Stoddard, D. R. 1971. "World Erosion and Sedimentation". in Water, Earth and Man, ed. Chorley, Methuern and Co., London, England.

U.S. Army Corps of Engineers. 1950a. Vol. 3 of Columbia River and

Tributaries. House Document 531, Appendix F, U.S. Government Printing Office, Washington, $D C$.

U.S. Army Corps of Engineers. 1950b. Vol. 7 of Columbia River and Tributaries. House Document 531, Appendix M, U.S. Government Printing Office, Washington, DC. 
U.S. Weather Bureau. 1945. Tentative Estimates of Maximum Flood Producing Conditions in the Columbia River Basin. Hydrometeorological Report No. 18.

U.S. Weather Bureau. 1965. Climatography of the United States. Report No. 60-45.

Viessman, W., J. W. Knapp, G. L. Lewis and T. E. Harbaugh. 1977. Introduction to Hydrology, 2nd ed., IEP, New York, NY. 

CHAPTER III

ANALYSIS OF THE SEISMIC HAZARD TO

AN UNDERGROUND WASTE REPOSITORY

L. H. Wight

TERA Corporation

\section{INTRODUCTION AND SUMMARY}

As with the siting of any critical facility, the successful siting of radioactive waste repositories hinges on the evaluation of all possible hazards at the site. This report addresses one of the most prominent hazards that could affect the repository--earthquakes.

The objectives of this report are to:

- provide the necessary seismological and earthquake engineering input to the WISAP repository simulation program

- evaluate qualitatively the overall possible effects of earthquakes on the repository

- develop a preliminary methodology for specifying a repository seismic design criteria.

Earthquake effects are classified as vibratory or fault displacement hazards. For each of these effects, the response of underground structures is qualitatively considered. This abbreviated consequence analys is is used to narrow the variables, and the different techniques that are available for probabilistic treatment of the hazard are then evaluated. After this evaluation, the most suitable technique to calculate the actual probability of the vibratory or displacement hazard is applied. 
Briefly, the conclusions are that:

- The consequence associated with intense vibratory shaking of a well-designed repository is essentially negligible.

- The specification of an appropriate seismic vibratory design criteria could best be accomplished with a Bayesian seismic hazard assessment, using geologic slip rates as input.

- The consequence associated with fault displacement is very site specific and dependent on the host geologic media and its permeability changes in response to fault displacement.

- The probability of faulting through a repository in its million year design life is rather high, principally because of a high probability of primary or secondary faulting on undetected faults.

- The faulting probability can be minimized by deploying sophisticated site certification programs. High resolution microseismic surveillance seems to be most appropriate to the author.

The author's judgment is that the repository simulation program can neglect consequences associated with shaking of the repository, but that the probability of significant fault displacement through the repository during its design life should be conservatively taken as one. Although the consequences associated with this event could be negligible depending on the mechanical and chemical properties of the medium, the data and analysis that would support such a firm conclusion have not yet, to the author's knowledge, been assembled.

\section{VIBRATORY SHAKING}

This section focuses on earthquake ground shaking. The vibratory shaking at a repository site is a function of the source mechanism of the earthquake, its distance, the properties of the intervening media, and the geometry and properties of the site area. These elements are all important, although in certain specific situations one or the other may dominate (e.g., attenuation through the roots of a mountain chain or amplification by site area topography). Depending principally on the distance and magnitude of the 
earthquake, ground motion excitation at a site can be expected to encompass accelerations in excess of $1 \mathrm{~g}$, velocities greater than $50 \mathrm{in./sec}$, at frequencies up to at least $50 \mathrm{~Hz}$., with total duration of the excitation exceeding 40 seconds. The possible range of these design parameters demand a careful definition of design criteria.

Of course, the design criteria must ultimately be set by weighing the consequences of a repository failure against the increased cost. Fortunately, a good deal is known about the response of underground structures to intense shaking. Perhaps the most relevant data are from underground nuclear explosions at the Nevada Test Site; the ground motion recorded in deep tunnels and boreholes often exceeds gravitational acceleration, $g$, by an order of magnitude. The motion is sufficient to cause spalling of walls. Even in these extreme dynamic environments, no tunnels or boreholes have been significantly damaged. Similarly, Dowding and Rozen (1978) have correlated earthquake damage in tunnels with ground motion to conclude that tunnels are much more resistant to damage than are surface structures. The only significant damage reported in the 40 tunnels examined was due to fault displacement rather than vibratory excitation.

These data and conclusions are for open tunnels and boreholes, in which the free surface would be expected to be the major contributor to the damage. A repository, on the other hand, will be completely backfilled and, assuming a well engineered backfilling process, the free surface effects will be minimized. Indeed, with careful attention to material acoustic impedances, the free surface effects can, in principle, be totally eliminated. In this ideal case, the ground motion parameters would be those appropriate for the original, virgin material. A recent study on subsurface ground motion for underground reactors (Applied Nucleonics Co., 1977) has led to the conclusion that the ground motion at depth in an undisturbed medium can be one-half to two-thirds of the ground motion experienced at the surface. This conclusion is consistent with independent calculations made several years ago (Wight, 1976).

The above arguments indicate that the ground motion likely to be experienced by the repository would be significantly less than a surface facility 
would experience. This fact is important in establishing the design criteria, but the actual consequence of such shaking is more essential. The author believes that the repository can be designed against failure from vibratory shaking. The only design requirements are that the backfill material acoustically match and maintain a bond with the host material even under extreme excitation. Although identification of the material or the backfill procedures is outside the scope of this study, the author is confident that appropriate identification of techniques and materials is available.

Based on the above, the author feels that vibratory excitation represents a negligible hazard to the repository, provided that the backfill has been properly engineered. To engineer the backfill correctly, one clearly needs seismic design criteria for the backfill. Accordingly, the techniques that are appropriate to set these criteria are outlined in Appendix A. The author believes, because of the long design life of the repository and its backfill, that:

- The assessment should be probabilistic.

- The input should, as much as possible, include the geologic history with the seismic history using geologic slip rates.

- The input should also include expert opinion in a Bayesian format. As an illustration, it can be calculated, using Bayesian hazard techniques for the Hanford Site, that the annual hazard of exceeding $20 \% \mathrm{~g}$ is less than $10^{-4}$.

\section{FAULT DISPLACEMENT}

In this concluding section, the hazard and risk associated with earth fracture through the repository are considered. The nature of the rupture depends on the mechanism of the earthquake (i.e., thrust, strike-slip, normal) and on the character of the host media. Although the physics of rupture propagation and the resulting overall rupture displacement are not well understood, it appears reasonable to relate the earthquake magnitude to the displacement. Data from previous earthquakes indicate that displacements from a single earthquake can be 20 feet or more. 
The consequences of rupture through the repository are very difficult to quantify. Like the design accelerations, they are very site specific. It depends on the character of the host media, the nature of the caprock, and the magnitude and direction of rupture. The efficiency of the pathway can be quantified by its relative permeability, and there are cases where earthquake rupture actually increased the permeability by scarifying the fault gouge zone. Although some relative permeability data exist for fault zones, they are based on surface measurements of rupture through the surficial soil. To the author's knowledge, there are no in situ data describing the relative permeability of deep rock fault zones, and any conclusions would, therefore, necessarily be based on laboratory data.

The author perceives that the displacement hazard originates in two distinct ways. First, there is the probability of an earthquake occurring on a fault not detected during site certification. Second, there is the probability of secondary faulting on a known fault adjacent to the site. Addressing this latter case will result in specification of a control zone for the site (the area around the repository that must contain no faults). The results for this latter case are summarized in Appendix B, where available data show that secondary faulting can be expected up to two miles from the main fault trace. The size of the zone of secondary faulting can be compared to the size of the control zone of three miles specified for nuclear power plants; in practice, a reactor can be sited no closer than three miles to a fault. The reasonable consistency between these two numbers leads the author to recommend that the three mile control zone be invoked for repositories.

Undetected faults are discussed in a study by Geotechnical Engineers, Inc. (1977). In reviewing previous interpretations of borehole logs for nuclear power plant foundations, they found that in 21 holes there were three separate undetected faults that were later discovered during excavation. More publicized are the number of critical facilities (nuclear power plants, dams, hospitals, etc.) found to be located near previously undetected faults. Indeed, Brooke's (1978) results are complementary to this discussion of faulting. His results indicate that the average density of faulting is roughly one fault per $10 \mathrm{~km}^{2}$. 
The above assessments, however, deal with the probability of an undetected fault and do not address the capability of the undetected fault. To obtain this perspective of the problem, the question was asked, "How reliable is geologic surface mapping, relative to microseismic surveys?"

In other words, if a site is subjected to reasonable scrutiny in surface geologic mapping, what is the likelihood that a microseismic survey of the site area will indicate activity on an unmapped fault? The results from over 25 microseismic arrays (referenced in Appendix $C$ ) were reviewed, and the hypocentral data were compared with the mapped surface geology. The surface mapping was, in every case, conducted with the precision of a typical USGS mapping program. Those situations with large discrepancies between the data and the map were typically areas of low to moderate levels of seismic activity and generally had a surface geology that obscured the bedrock geology. What was surprising was the degree to which the mapping and the data were uncorrelated for these situations. For example, in a microseismic surveillance of the Flathead Lake area of Montana, the author judges that less than $20 \%$ of the activity could be attributed to mapped faulting. In the state of Washington, perhaps less than $10 \%$ of the microseismicity can be associated with mapped faults. In the eastern United States, the hypocenters are deep enough that it is difficult to associate microseismicity with faults. As a result, by current criteria, there are no known active faults--even though there is seismic activity which is, in some localities, quite intense.

Due to the fact that geologic mapping and microseismic monitoring are two key site certification tools, this lack of correlation further raised the author's doubts that all faults would be detected.

As a final assessment for undetected faults, the unassociated microseismicity in central Washington was analyzed. If this unassociated activity is assumed to be related to undetected or unknown faults, the results provide an estimate of the probability of unanticipated faulting in the site area. In this estimate, the relationship between geologic slip rate and seismicity was used to infer a recurrence relation (Anderson, 1978; TERA, 1978). Starting with an average strain rate of $3 \mathrm{~km} / 4 \mathrm{million}$ years, covering a central 
Washington area of $10^{5} \mathrm{~km}^{2}$, it is estimated that there is roughly a $50 \%$ probability that an unexpected, moderately-sized earthquake would occur in a $100 \mathrm{~km}^{2}$ site area, at least once in the design life of the repository. This earthquake would result in a significant displacement and therefore could provide a significant breach.

There are, of course, many uncertainties in an assessment of undetected faults. However, considering all of the above, information the probability is very high that faulting will occur through the repository during its life.

\section{REFERENCES}

Anderson, J. G. 1979. "Estimating the Seismicity from Geologic Structure for Seismic Risk Studies." Bulletin of the Seismological Society of America, Vo 1. 69, No. 1, pp. 135-158. .

Applied Nucleonics Co., Inc. 1977. "Summary of Seismic Assessment of Underground and Buried Nuclear Power Plants." P.0. Box 24313, Village Station, Los Angeles, CA 09927.

Brooke, J. 1978. Geomathematical Investigation of Fault Populations at Selected Locations, 19th U.S. Rock Mechanics Symposium, Lake Tahio, CA May 1-3, 1978.

Dowding, C. H. and Rozen, A. 1978. "Damage to Rock Tunne ls from Earthquake Shaking." ASCE Geotechnical Journa1, Vol. 14, pp. 175-192.

Geotechnical Engineers, Inc. 1977. Report to Lawrence Livermore Laboratory.

TERA Corporation. 1978. "Seismic Risk Analysis for the Al NMDF, Santa Susana, California." 2150 Shattuck Avenue, Berkeley, CA 94714.

Wight, L. H. 1975. "Site Response Calculations for Nuclear Power Plants," UCRL 77371. Lawrence Livermore Laboratory, P.0. Box 808, Livermore, CA 94550. 


\section{APPENDIX A}

One of the seismic hazards for underground waste disposal sites involves possible damage resulting from earthquake shaking. This hazard, which can conveniently be associated with distant earthquakes, can be assessed with adaptations of currently available seismic hazard methodologies. What makes the WISAP application unique is the operating life of the facility and the period of time over which, therefore, assessment must be made. The author believes that state-of-the-art seismic hazard techniques, coupled with appropriate geologic input, could provide realistic estimates of the seismic hazard of vibratory ground motion of the site.

The geologic information that is appropriate for coupling to a seismic hazard analysis relates to the relative motion of tectonic plates within the earth's lithosphere. The movement is manifested as slip along major and minor plate boundaries and can be related to the recurrence of earthquakes. Due to the fact that the geologic record covers more than $10^{5}$ years of geologic history, this information provides more realistic estimates of earthquake recurrence over the life of a repository than the historical seismic record, which covers on 1 y $10^{2}$ years.

There are a variety of seismic hazard analysis techniques currently available, each of which uses the geologic-based input discussed above.

In the following paragraphs the results of generic site analyses using several different techniques are presented. The comparison is presented for two reasons: first, to present typical results for a possible generic site, and second, to present the relative advantages and disadvantages of the techniques. This comparison is based on the work of Mortgat and Patwarden (1978).

Each of the models studied for this comparison has relative advantages and disadvantages in the way it handles the key elements of the seismic hazard analysis. The key elements are:

- source region geometry

- earthquake recurrence model

- tectonic model and travel path

- uncertainty analysis. 
The combined effect of the various assumptions regarding the above parameters is reflected in the differences in exposure evaluation. However, the contribution of each of them to the overall variation cannot usually be assessed.

The comparison presented herein was conducted to determine the factors influencing these differences and their implications for exposure evaluation.

A generic situation intended to represent a typical seismological setting was developed. The models were compared on the bas is of peak ground acceleration (PGA) versus return periods for a number of sites.

We employed the following four commonly used models in the comparison:

- Cornell (1974)

- McGuire (1976)

- Der Kiureghian (1977)

- Mortgat (Stanford 1977).

Table III-A.1 presents the main characteristics of each mode1. They can be summarized as follows:

TABLE III-A.1

\begin{tabular}{|c|c|c|c|c|}
\hline \multirow{3}{*}{ Source Geometry } & Corne 11 & McGuire & Der Kiureghian & Stanford \\
\hline & - Point & - Quadrangle & - Line & - Line \\
\hline & - Annular segment & & - Area & $\begin{array}{l}\text { - Area } \\
\text { - Dipping plane }\end{array}$ \\
\hline
\end{tabular}

$\begin{array}{llll}\text { Tectonic Mode1 No rupture } & \text { No rupture } & \text { Rupture } & \text { Rupture } \\ & & \text { Poisson } & \text { Poisson }\end{array}$
Occurrence Model Poisson Poisson Poisson Poisson + Bermouli i + Bayesian Attenuation Uncertainty
Log - Norma 1
Log - Normal
Log - Normal Log - Norma 1 


\section{Geometry}

Cornel1 represents sources as point sources and annular segments. A straight line source can be represented by a series of points in such a way that the difference from discrete to continuous medium is negligible. Area sources are divided into a series of annular segments. The procedure has the inconvenience of requiring a fairly cumbersome input.

McGuire accepts only quadrangles. These quadrangles are internally divided into a specified number of annular rings. Line sources have to be modeled by long, thin rectangles.

Der Kiureghian uses line sources and area sources. The areas are input as a series of similar rings.

Mortgat uses line sources, trapezoid area sources and dipping plane sources. Any number of trapezoids or triangles can be combined to form a surface. This procedure has the advantage of introducing a third dimension in the analysis. In the other models, all sources are at a constant depth, and therefore the future seismic activity is restricted in depth. Here, the use of dipping planes allows for a closer modeling of real faults, on which the seismic activity is spread over a range of depths.

Tectonic Model

Corne 11 and McGuire assume that the total energy released during an earthquake is radiated from the hypocenter (point model). The maximum intensity at a given site is governed by its distance from the hypocenter. Although this assumption may be valid for small magnitude earthquakes, it does not apply to large magnitude events, for which the length of fault rupture can be several hundred kilometers.

Der Kiureghian and Mortgat associate rupture with energy release, and the intensity of ground shaking is determined by the slip that is the closest to the site (significant distance). In a 11 cases, the significant distance is shorter than the hypocentral distance that is used by point rupture models. Therefore, a significant underestimation of the hazard will result from a nonrupture model in a region where an important large magnitude activity is expected. 
Occurrence Model

In all cases the basic earthquake occurrence is assumed to follow a Poisson process. Although this assumption can be conceptually criticized because it does not take into account the cyclic phenomenon of stress buildup and release, it has been shown to adequately model earthquake occurrences (Gardner and Knopoff, 1974). The distribution on the different magnitude occurrences is introduced either directly in the Poisson model by using variable mean rate of occurrences or indirectly by combining the occurrence model with a distribution on magnitudes.

In Mortgat, the above is treated using Bayesian statistics. This treatment implies that rather than using deterministically behaving models (i.e., Poisson with a fixed mean rate of occurrences describing the future activity in probabilistic terms) uncertainty is associated with the behavior of the model itself (i.e., the mean rate of occurrence is treated as a random variable). The uncertainty in the behavior of the model is obtained from two sources. The first one consists of the opinion of an expert asked to formulate his judgement based on past experience. The second one is the recorded data which, however incomplete, constitute an important piece of information. Both are combined with different weights implicitly given by the expert as he expresses his opinion. This method has the advantage of providing a method by which insufficient or biased data can be modified by subjective input in a consistent manner. The method is general enough to permit the use of the data only when the expert's opinion is not required or is too vague. It also allows for the use of only the subjective information when no data are available. Attenuation Uncertainty

Each of the models treat the scatter of the data about the attenuation relation in exactly the same way. They consider a log-normal distribution with respect to the median value of attenuation. Therefore, this parameter does not introduce any variation in the comparison.

In order to conduct the comparison, TERA analyzed a generic site setting in a region of relatively low seismicity where earthquakes cannot be associated with specific geological features. A typical eastern or northwestern United States site would fit this description. 
The key elements considered for the seismic hazard analys is were:

- source region geometry

- earthquake recurrence mode 1

- tectonic model and travel path

- uncertainty analysis.

As described previously, each of the methods examined herein treats these elements differently. In order to make a valid comparison, all of the parameters of the analysis were kept constant as much as possible. The only modifications that were introduced concerned variations in input requirements from program to program.

As set forth above, this example was developed as a region of fairly low seismicity. Because past epicenters appear clustered within definite regions and cannot be associated with specific geological features, the seismic sources were defined as four areas at a depth of $15 \mathrm{~km}$. The geometry of these sources is presented in Figure III-1. A series of annular segments used in Cornell's program is overlaid on the top of Source 1. This procedure introduces some approximation, but, most importantly, requires a major input effort. The site distance to the closest source is $43 \mathrm{~km}$ and $154 \mathrm{~km}$ to the furthest source.

The seismicity of the sources is represented by a typical linear recurrence relationship with abrupt cutoff (see Figure III-2). Such simplified input is used because some codes have limitations as to the use of a piecewise linear or nonlinear relationships. In the Bayesian model, the subjective input is taken to be similar to the historical data. It assumes that the expert's opinion regarding the seismicity of the sources matches exactly the past earthquake history. It therefore reduces any variation of seismic activity between the models and presents a more meaningful comparison. 

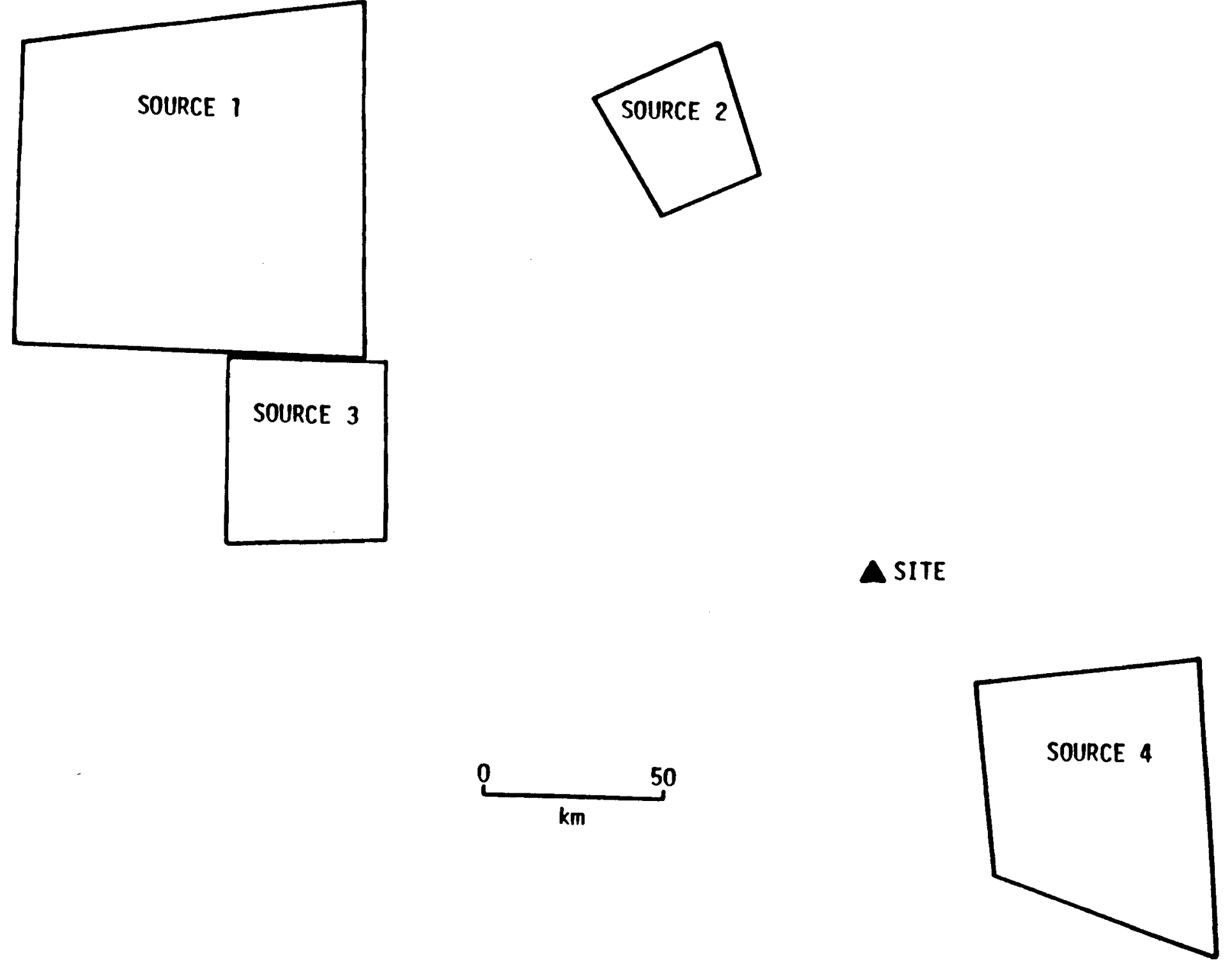

FIGURE III-1. Low Seismicity Region 


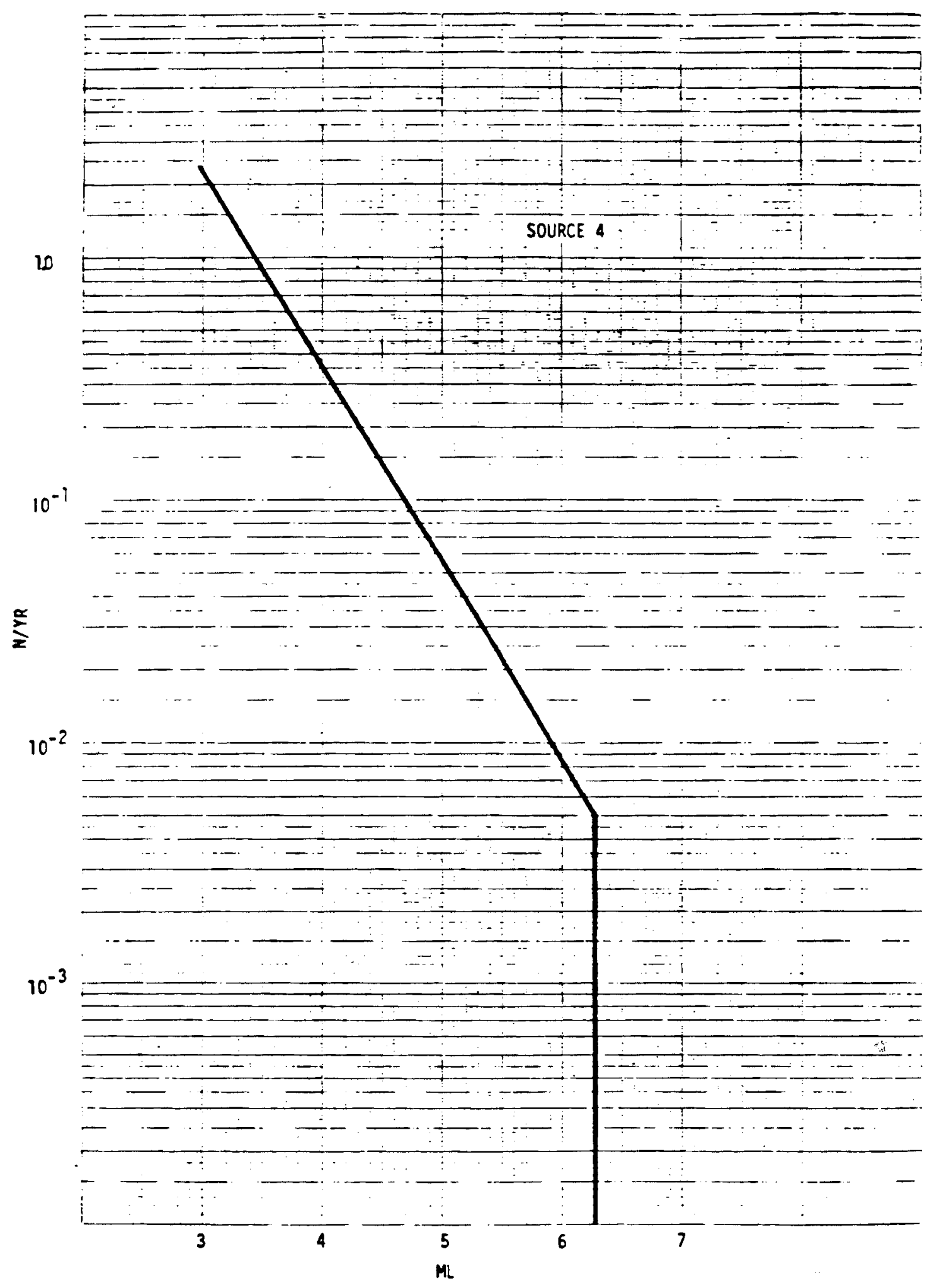

FIGURE III-2. Typical Recurrence Relationship 
The attenuation relation used in this example is from McGuire (1974):

$$
a_{g}=\frac{472 \times 10^{.28 M}}{(R+25)^{1.3}}
$$

where

$$
\begin{aligned}
a_{g} & =\text { Peak Ground Acce leration }\left(\mathrm{cm} / \mathrm{s}^{2}\right) \\
\mathrm{R} & =\text { hypocentral or significant distance }(\mathrm{km}) \\
\mathrm{M} & =\text { local magnitude }
\end{aligned}
$$

with dispersion value $\log _{\mathrm{g}}=0.22$

Although there are several models for attenuation, McGuire's model is representative and therefore satisfied the needs of the analysis.

The annual hazard expressed in terms of peak ground acceleration is presented in Figure III-3. The curves show that all models give very similar results. The differences can be attributed to approximations introduced in the geometry to satisfy input requirements and in differences in the computer algorithms. Also, the rupture model does not introduce any increase in exposure. This lack of increase is expected because the magnitudes of interest generate very small or no ruptures.

On the basis of this analysis and comparison, the author concludes that:

- Probabilistic seismic hazard analysis is an assessment tool that can credibly be applied to WISAP.

- In regions of relatively low seismicity, Bayesian approaches to seismic hazard estimations do not provide significantly better hazard estimates.

- Neverthe less, had there been a larger uncertainty in the earthquake statistics or their locations, a Bayesian approach could be shown to be distinctly better.

\section{REFERENCES}

Mortgat, C. P. and Patwarden, A. S. and Idriss, I. M. 1978. "Influence of Seismicity Modeling of Seismic Exposure Evaluation." Seventy-Third Annual Meeting of Seismological Society of America, April 6-8, 1978. . 


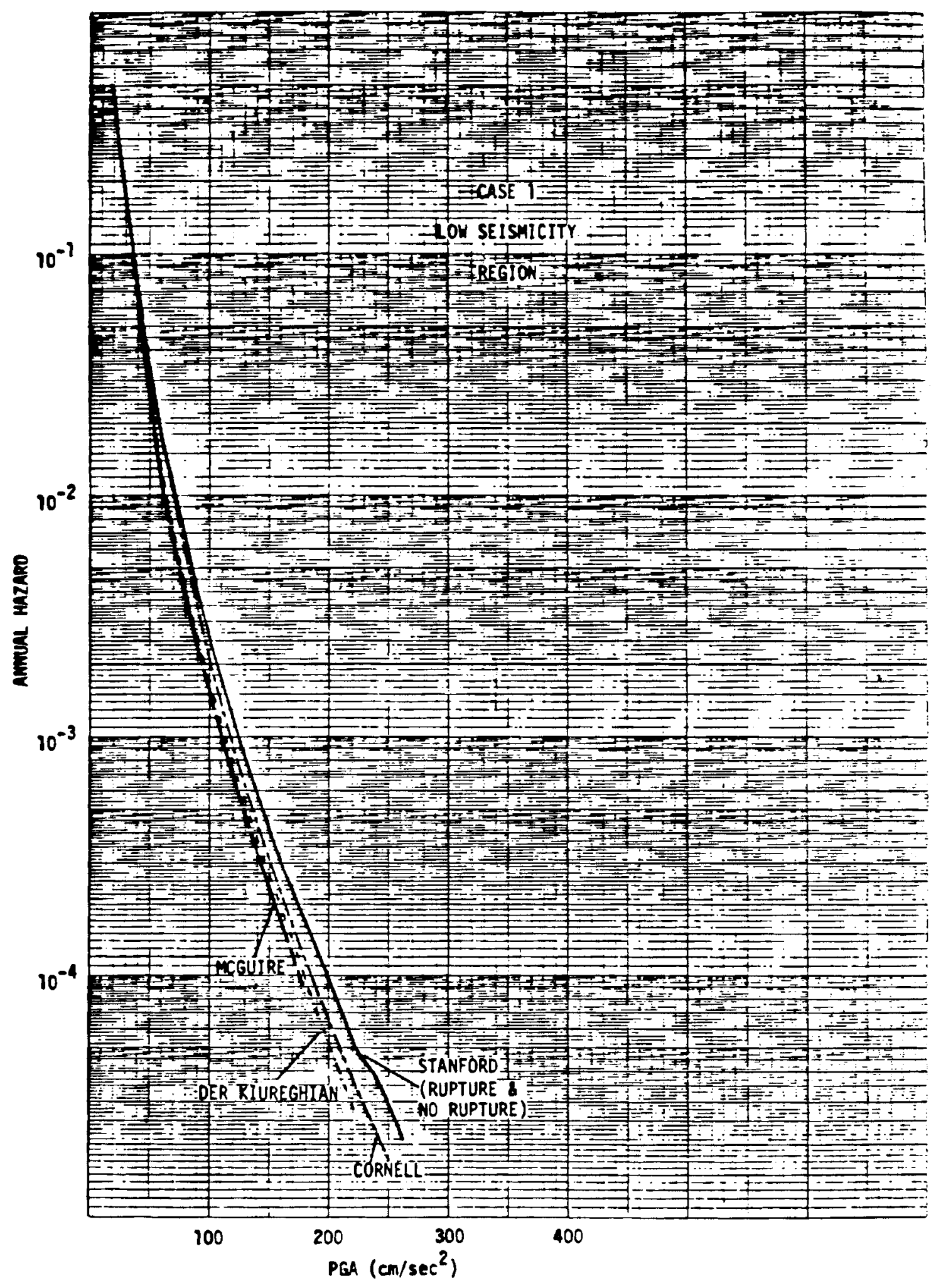

FIGURE III-3. Seismic Hazard 
APPENDIX B

The author believes that the most relevant mode of faulting in the Columbia Plateau Region is thrust faulting. First of all, it is likely that a repository will be constructed in a syncline-anticline geologic environment, and second, it is likely that the distribution associated with surface rupture from a thrust fault is probably the widest compared to other faulting modes. In the following paragraphs an approach that can yield the desired distribution is presented.

Four we11-documented cases of known surface thrust faulting were selected, and each of these cases was reviewed for geometry of surface displacement. The four cases reviewed for their surface thrust faulting characteristics were selected from 17 cases of reverse slip earthquakes which caused surface rupture. Table III-B.1 presents a general summary of their characteristics. The four earthquakes have occurred within about the past 25 years and had magnitudes between 6.4 and 8.4. The fault lengths were found to vary widely (6-63 km), yet the maximum vertical displacements for all but the 1964 Alaska earthquake were between 1 and $2 \mathrm{~m}$. In each of these cases the underlying bedrock was a very competent hard rock. The alluvium overburden was generally thin in the rupture area (less than a few meters) and appeared to have no noticeable control on subsidiary faulting. However, the thickness of sedimentary layers underlying the thin alluvium cover did appear to affect surface faulting. Apparently, in zones of increased thickness of the sedimentary series, the surface features were found to die out.

To develop a probabilistic assessment of the potential for ground rupture from a thrust fault, the spatial distribution of subsidiary faulting associated with thrust faults was considered. The mapped geomorphic features that resulted from each earthquake were examined closely. These features included all subsidiary surface faulting reported within several kilometers of the main rupture and any other significant surface features such as fissures or cracks which might have developed. Surface features which were discontinuous but which had a similar trend and constant spatial relationship to the main rupture were considered as a single feature. Basically, features which tended to parallel the principle rupture were considered. Even branch faulting, although 


\section{TABLE III-B.1. Thrust Faults}

\begin{tabular}{|c|c|c|c|c|c|c|c|c|c|c|}
\hline Location & Date & Magnitude & $\begin{array}{l}\text { Fault } \\
\text { Length }\end{array}$ & $\begin{array}{c}\text { Max. Vert. } \\
\text { Displacement }\end{array}$ & Dip & $\begin{array}{l}\text { Bedrock/ } \\
\text { Geology }\end{array}$ & $\begin{array}{c}\text { Type and } \\
\text { Thickness of } \\
\text { Overburden }\end{array}$ & $\begin{array}{l}\text { Max. Width of } \\
\text { Subsidiary } \\
\text { Fault Zone } \\
\end{array}$ & $\begin{array}{l}\text { Max. Length } \\
\text { of a } \\
\text { Cont inuous } \\
\text { Subsidiary } \\
\text { Fault Zone } \\
\end{array}$ & $\begin{array}{c}\text { Location of } \\
\text { Subsidiary Zone }\end{array}$ \\
\hline $\begin{array}{l}\text { Meckering } \\
\text { Hestern } \\
\text { Australia }\end{array}$ & $10 / 14 / 68$ & 6.9 & $37 \mathrm{~km}$ & $1.8 \mathrm{~m}$ & $\begin{array}{l}15-55^{\circ} \\
\text { Avg. } 40^{\circ}\end{array}$ & $\begin{array}{l}\text { Precambrian } \\
\text { Granitic }\end{array}$ & $\begin{array}{l}1 \mathrm{~m} \mathrm{clay} / \mathrm{s} \text { and } \\
\text { variable thick- } \\
\text { ness of deeply } \\
\text { weathered bedrock }\end{array}$ & $1.5 \mathrm{~km}$ & $3 \mathrm{~km}$ & Hanging wall \\
\hline $\begin{array}{l}\text { Avvin-Teha } \\
\text { chapi Kern } \\
\text { Co., CA }\end{array}$ & $7 / 21 / 52$ & 7.7 & $53 \mathrm{~km}$ & $1.2 \mathrm{~m}$ & $5-20^{\circ}$ & $\begin{array}{l}\text { Jurassic } \\
\text { Granitic }\end{array}$ & $\begin{array}{l}\text { Sedimentary } \\
0 \text { to } 85 \mathrm{~m} \text { (thin } \\
\text { in rupture zone) }\end{array}$ & $1.4 \mathrm{~km}$ & $8 \mathrm{~km}$ & Hanging wall \\
\hline \multirow[t]{2}{*}{$\begin{array}{l}\text { San Fer- } \\
\text { nando, CA }\end{array}$} & $2 / 9 / 71$ & 6.4 & $15 \mathrm{~km}$ & $1 \mathrm{~m}$ & $20-25^{\circ}$ & $\begin{array}{l}\text { Pre-Ceno- } \\
\text { zoic Cry- } \\
\text { stalline }\end{array}$ & $\begin{array}{l}0-6 \text { m alluvium } \\
\text { variable thick- } \\
\text { ness of sedi- } \\
\text { mentary rocks }\end{array}$ & $\begin{array}{c}1.4 \mathrm{~km} \\
\text { (Principal } \\
50-200 \mathrm{~m}\end{array}$ & $\begin{array}{l}\text { Zone) } \\
2.7 \mathrm{~km}\end{array}$ & \multirow[t]{2}{*}{ Hanging wall } \\
\hline & \multirow[b]{2}{*}{$3 / 27 / 64$} & \multirow[b]{2}{*}{8.4} & $6.4 \mathrm{~km}$ & $6 \mathrm{~m}$ & & & $2 \mathrm{~m}$ & $\begin{array}{c}88 \mathrm{~m} \\
\text { (Hanning Bay }\end{array}$ & $\begin{array}{l}140 \mathrm{~m} \\
\text { Fault) }\end{array}$ & \\
\hline Alaska & & & $63 \mathrm{~km}$ & $7.9 \mathrm{~m}$ & $50-85^{\circ}$ & $\begin{array}{l}\text { Early } \\
\text { Tertiary } \\
\text { harder } \\
\text { sediments }\end{array}$ & $\begin{array}{l}\text { Variable thick- } \\
\text { ness of glacial } \\
\text { till and coarse } \\
\text { alluvium }\end{array}$ & $\begin{array}{l}1 \mathrm{~km} \\
\text { Only fissures } \\
\text { (Patton Bay } \mathrm{F}\end{array}$ & $\begin{array}{l}\text { and cracks } \\
\text { ault) } 15 \mathrm{~km}\end{array}$ & Hanging wall \\
\hline
\end{tabular}


often distant from the main rupture and tending to be transverse to the main rupture's trend, was included. The tabulated statistics consisted of the cumulative number of subsidiary features per $100 \mathrm{~m}$ increments on either side of the main fault rupture. The $100 \mathrm{~m}$ increment was selected based on the scale of the maps studied and the maximum lateral extent of subsidiary faulting noted.

The data indicated that the density faulting was understandably much greater on the hanging wall side than on the foot wall side and that more than 957 of the secondary and branch faults were contained in a two mile wide zone.

APPENDIX C

Microseismic Array Reference List

Bollinger, G. A. 1973. Seismicity of the Southeastern United States. BSSA, v. 63 , pp. 1785-1808.

Bollinger, G. A., C. J. Langer and S. T. Harding. 1976. The Eastern Tennessee Earthquake Sequence of October through Decamber, 1973. BSSA, v. 66, pp. 525-547.

Bolt, B. A., J. Stifler and R. Uhrhammer. 1977. The Briones Hills Earthquake Swarm of January 8, 1977, Contra Costa County, California. BSSA, v. 67, pp. 1555-1564.

Ellsworth, W. L. 1975. Bear Valley, California, Earthquake Sequence of February March, 1972. BSSA, v. 65, pp. 483-506.

Freidline, R. A., R. B. Smith and D. D. Blackwell. 1976. Seismicity and Contemporary Tectonics of the Helena, Montana Area. BSSA, v. 66, pp. 81-95.

Greensfelder, R. 1968. Aftershocks of the Truckee, California, Earthquake of September 12, 1966. BSSA, v. 58, pp. 1607-1620.

Hadley, D. and J. Combs. 1974. Microearthquake Distribution and Mechanisms of Faulting in the Fontana - San Bernardino Area of Southern California. BSSA, v. 64, pp. 1477-1499.

Langen, K. P. and J. Combs. 1974. Microearthquake Study of the Elsinore Fault Zone Southern California. BSSA, v. 64, pp. 187-203.

Lee, W. H. K., M. S. Eaton and E. E. Brabb. 1971. The Earthquake Sequence Near Danville, California, 1970. BSSA, v. 61, pp. 1771-1794. 
Malone, S. D., G. H. Rothe and S. W. Smith. 1975. Details of Microearthquake Swarms in the Columbia Basin, Washington. BSSA, v. 65, pp. 855-864.

McEvilly, T. V. 1966. The Earthquake Sequence of November 1964 Near Corralitos, California. BSSA, v. 56, pp. 755-773.

McEviliy, T. V., and K. B. Casaday. 1967. The Earthquake Sequence of September, 1965, Near Antioch, California. BSSA, v. 57, pp. 113-124:

McEvilly, T. V., W. H. Bakun and K. B. Casaday. 1967. The Parkfield, California Earthquakes of 1966. BSSA, v. 57, pp. 1221-1244.

McNally, R. C., G. W. Simila and F. J. VonDollen. 1978. Microearthquake Activity Adjacent to the Rocklin Pluton Near Auburn, California. BSSA, v. 68, pp. 239-243.

Morrison, P. W., B. W. Stump and R. Uhrhammer. 1976. The Oroville Earthquake Sequence of August 1975. BSSA, v. 66, pp. 1065-1084.

Pitt, A. M. and D. W. Steeples. 1975. Microearthquakes in the Mono Lake-Northern Owens Valley, Cal ifornia, Region from September 28 to October 18, 1970. BSSA, pp. 835-844.

Rogers, A. M. and W. H. K. Lee. 1976. Seismic Study of Earthquakes in the Lake Mead, Nevada-Arizona Region. BSSA, v. 66, pp. 1657-1681.

Savage, W. U., D. Tocher and P. C. Birkhahn. 1975. Microearthquake Study of the Oroville, California Earthquake Sequence of August 1975. In California Division Mines and Geol. Spec. Report 124, pp. 123-129.

Sbar, M. L., J. Armbruster and Y. P. Aggarwa11. 1972. The Adirondack, New York, Earthquake Swarm of 1971 and Tectonic Implications. BSSA, v. 62, pp. 1303-1317.

Sbar, M. L., R. R. Jordan, C. D. Stephens, T. E. Pickett, K. D. Woodruff and C. G. Sammis. 1975. The Delaware-New Jersey Earthquake of February 28 , 1973. BSSA, v. 65, pp. 85-92.

Sbar, M. L. and L. B. Sykes. 1977. "Seismicity and Lithospheric Stress in New York and Adjacent Areas." J. G. P. 82:5771-5786.

Stander, W., M. Kramer, G. Fischer and S. T. Morrisey. 1976. Seismic Characteristics of Southeast Missouri as Indicated by a Regional Telemetered Microearthquake Array. BSSA, v. 66, pp. 1953-1964.

Stevenson, P. R. 1976. Microearthquakes of Flathead Lake, Montana: A Study Using Automatic Earthquake Processing. BSSA, v. 66, pp. 61-80. 
Thatcher, W. and R. M. Hamilton. 1973. Aftershocks and Source Characteristics of the 1969 Coyote Mountain Earthquake, San Jacinto Fault Zone, California. BSSA, v. 63, pp. 647-661.

Whit comb, J. H., C. R. Allen, J. D. Garmany and J. A. Hileman. 1973. "San Fernando Earthquake Series, 1971: Focal Mechanisms and Tectonics." Rev. Geophysics and Space Physics 11:693-730. 

CHAPTER IV

\title{
GLACIOLOGICAL PARAMETERS OF DISRUPTIVE EVENT ANALYSIS
}

\author{
C. Bul1
}

Ohio State University

\section{WORLD-TO-SITE SPECIFIC COUPLING OF CONTINENTAL GLACIATION}

Possible changes in the glaciological conditions on earth range from the growth of a complete ice cover over the entire globe (Budyko, 1978) to the complete deglaciation of the planet (in which case all considerations of waste isolation safety assessment will seem trivial). Possible intermediate states include extensive reglaciations of the Northern Hemisphere and existence of conditions similar to those of the present.

The possibility of complete glaciation of the earth is small and probably need not be considered in the consequence analysis by the Waste Isolation Safety Assessment Program (WISAP). On the other hand, abundant evidence exists (e.g., Hays et a1., 1976; Kennett and Shackleton, 1975; Shackleton and Opdyke, 1973) that the quantity of ice on the earth has varied over the last million years. For the 1 ast 600,000 years, the glacial cycles have had a period of about 100,000 years. The cause of the variations is not known; it may be variations in the solar constant, changes in the geometry of the earthsun system (Weertman, 1976; Berger, in press, a and b), variations in the microparticle content of the atmosphere (Gow and Williamson, 1971; Thompson et a1., 1975; Hammer, 1977) or other phenomena.

In any case, it is prudent to assume that the variations in ice cover will continue. The next glaciation of North America (and other parts of the Northern Hemisphere) could correspond with an ice volume of -1 on the scale of Shackleton and Opdyke (1973), which is equivalent to ice-sheets up to $600 \mathrm{~km}$ more extensive than the Wisconsin Ice Sheet was in the low-lying areas of North America. On Berger's mode1, presented by M. Schwartz at the Battelle 
Workshop (Seattle, WA, 1978), this reglaciation could start in 4000 A.P. (years after the present). After that time, according to the Milankovitch model, the next significant "low" in Northern Hemisphere radiation appears to be in 60,000 A.P. The probability that continental ice will cover Columbus, Ohio (near the maximum of the Wisconsin glaciation) within the next 4000 years or so has been estimated variously at 0.25 to 0.50 . The probability of at least one such glaciation in the next million years is close to 1 .

It must be emphasized that these probabilities are based on the assumption that man's technology will not have advanced to the stage where, within 4000 years, he will be able to control climate to the extent necessary to offset the effects of natural variations, Milankovitch or otherwise (Kellogg, 1978). The present writer, without hard evidence, believes that such technology (perhaps for controlling $\mathrm{CO}_{2}$ content of the atmosphere) will develop.

Ignoring such possible control, within a few thousand years an ice sheet may well cover proposed waste disposal sites in Michigan. Those in the Gulf Coast region and New Mexico are unlikely to be ice covered. The extent of mountain glaciation at the Wisconsin maximum has been mapped, as part of the CLIMAP program, by John Hollin. The area in southeastern Washington on which the Hanford Site is now located was not ice covered, but the ice-edge of mountain glaciation was only scores of kilometers away. Also, lobes of the Cordilleran ice sheet (responsible in part for the Lake Missoula floods) invaded the northern part of Washington State. The probability of ice cover at Hanford in the next million years is finite, perhaps about 0.5 .

The reconstructions of the Wisconsin ice sheet in North America (Sugden, 1977; CLIMAP project, 1976), when extended to other parts of the northern hemisphere, indicate a minimum sea-level drop at 18000 B.P. of 126 meters and a maximum of about 165 meters. With a glaciation equivalent to -1 on Shackleton and Opdyke's scale, a sea-level drop of nearly 200 meters is possible. M. Schwartz, an expert on sea-level fluctuations, gave a similar number for possible sea-level lowering at the Battelle Workshop. 
Within the present interglacial period there is a definite chance that the West Antarctic ice sheet will melt. This melting would be due primarily to increased temperatures resulting from increased $\mathrm{CO}_{2}$ in the atmosphere (Broecker, 1975; Mercer, 1978). The probability is estimated at less than 0.1. Such a melting would cause a sea-level increase of about seven meters. There is a lesser chance, perhaps 0.05 , that the Greenland ice sheet will melt in the same period, although it can be considered as not being in equilibrium; if it melted, the Greenland ice sheet would not regenerate under present climatic conditions (Weertman, 1964). Sea level would rise about seven meters if the Greenland ice sheet melted.

With increased atmospheric temperatures in the Antarctic there would be a slow (Whillans, in press) change in basal temperatures of the ice sheet. There would also be a change from freezing to melting conditions in significant areas of East Antarctica (Weertman, 1966; Nye, 1976), perhaps accompanied by major surges of the ice sheet (Hollin, 1977), changes of the earth's albedo, and the initiation of Northern Hemisphere glaciations (Wilson, 1964). Changes in atmospheric temperature may not be necessary to initiate the surges (Budd, 1975).

There is no evidence that the Antarctic ice sheet has disappeared completely in the last four million years. (e.g., Drewry, 1976; Stuiver et al., 1976; Mayewski, 1975; Calkin et al., 1970). On this lack of evidence it is estimated, without much confidence, that the probability of the Antarctic ice sheet melting in the next million years is 0.25 . Such a melting, accompanied by melting of the Greenland ice sheet, would raise sea level by 60 to 70 meters (Hollin, 1962). In the next 4000 years the maximum sea-level increase, resulting from melting of the Greenland and West Antarctica ice sheets, may perhaps be about 12 meters.

There is little chance, perhaps 0.01 , that the Greenland ice sheet will remain intact for one million years. Either Greenland or West Antarctica may not have been covered in the last interglacial, when sea level was a few meters higher than at present (Shackleton and Opdyke, 1973; Shackleton and Matthews, 1977). M. Schwartz also agreed with this statement at the Battelle Workshop. 
An extreme view of the erosive powers of continental ice sheets is given by White (1972), who argues that the late Quaternary ice sheets of North America caused erosion of hundreds of meters into the Canadian Shield. Mathews (1975) and especially Sugden (1976) contend that, as an average over the glaciated area, only a few tens of meters of erosion (which may be of previously weathered regolith as opposed to bedrock) is indicated. There were perhaps three meters of erosion per glaciation cycle. Sugden (1976 and 1977) argues that deep selective linear erosion can occur near the ice sheet margin, although the periphery of an ice sheet is normally a depositional environment. Erosion at the ice sheet margin is accomplished by streams produced by local thawing of the ice base. The Finger Lakes are an example of erosional features formed near the margin of an ice sheet.

The erosion of the basins of the Great Lakes is probably also due to ice sheet action, possibly associated with fracturing of the crust under the ice sheet 1oad. (Brotchie and Silvester, 1969; Whillans, 1978). There are no "relict Great Lakes." Lakes which were cut out perhaps 500,000 years ago have not been filled with Quaternary material, as would be the case if centers of erosion had shifted elsewhere in later glaciations. The absence of these relict lakes leads one to conclude that in future glaciations of North America, deep erosion by ice action will occur only in those areas where deep erosion has already occurred.

From the quantity of sediments carried to the deep Atlantic by ice rafting and otherwise, Ruddiman (1977) calculated that an average of 16 meters of material had been eroded in the last three million years. Lane (unpublished), in a similar study, obtained 20 meters. These are likely to be minimum erosion rates, because these studies ignore the erosion products in solution and fine suspension.

\section{LIMITS ON LOADING AND SUBSIDENCE}

The two best reconstructions of the Laurentide ice sheet of North America (Sugden, 1977; CLIMAP, 1976) give similar values for the extent, thickness and bottom conditions. Sugden's model, based on the form of the Greenland and 
Antarctic ice sheets, gives a maximum ice thickness of $4244 \mathrm{~m}$ in the westcentral part of Hudson Bay. The CLIMAP reconstructions attempt to use more glacial geology control, in which the bottom conditions are first inferred from observed erosion and depositional patterns, and so on. The "maximum" mode 1 has a maximum ice thickness of 4960 m west of Hudson Bay. The "minimum" model gives three "domes"; one dome has a thickness of $4260 \mathrm{~m}$ west of Hudson Bay, the second dome has a thickness of $4230 \mathrm{~m}$ over James Bay, and the third dome is a lower one over Fox Basin.

Loads at specific points can be calculated directly from the reconstruction maps of ice thickness. Future ice sheets may be more extensive than the Laurentide; the ice sheet margin could be up to 600 kilometers further south in the U.S. midwest, as in the "Kansan" stage (Flint, 1971). The form of the profiles of the more extensive ice sheets should closely resemble those of the Laurentide ice sheet, with maximum thicknesses increased by only a few hundred meters over the Laurentide values.

Members of CLIMAP have calculated depressions of the earth's crust using two different models. In one model the isostatic processes are assumed to occur in the crust (so that the density ratio of ice:displaced material is $1: 3$, and the maximum depression is thus about 1500 meters). In the other mode 1 (Brotchie and Silvester, 1969) isostatic adjustments occur in the mantle (giving a density ratio of $1: 4$ and a minimum value for the greatest depression of about $1000 \mathrm{~m}$ ).

Permeabilities of earth material below the ice sheet at equivalent elevations relative to a fixed datum should not be affected by ice-sheet loading and subsequent subsidence.

Loading and subsidence due to reglaciation of North America are not likely to directly affect proposed disposal sites in the Gulf Coast region or New Mexico. The Hanford Site could be affected by the "forebulge" (Brotchie and Silvester, 1969) from a Cordilleran ice sheet, but change of elevation is not likely to exceed a few meters. Similarly, changes in elevation at Hanford due to the direct depression, or forebulging, from a neighboring mountain ice cap are not likely to be significant. 
Loading of the Gulf of Mexico might produce a sea-level fall of 200 meters or a rise of 70 meters. The effect of these changes on the proposed disposal sites in the Gulf Coast region should be calculated, but it does not seem likely that they will be significant.

\section{POTENTIAL FOR AND MAGNITUDE LIMITS OF DEEP GROUND WATER RECHARGE}

Under glacial conditions the surface boundary conditions for ground water recharge will be appreciably changed. Below the ice sheet or glacier, surface water will be under a hydrostatic pressure because of the load of ice. This pressure may be up to more than 400 bars where the ice sheet is thickest. Free water will exist over appreciable areas of the ice sheet bed. The areas of melting under the Laurentide ice sheet are shown in the maps of Sugden (1977) and CLIMAP (1976). The melt water is generated by the geothermal heat flux, which varies over the area of the Laurentide ice cover from 1 to about $1.7 \times 10^{-6} \mathrm{cals} \mathrm{cm}^{-2} \mathrm{sec}^{-1}$ (Sugden, 1977). Melt water is also generated by the frictional heat produced by ice slipping over the bed and by internal deformation near the base of the ice sheet. The quantity of free water generated varies under these conditions between $0.5 \mathrm{~cm}$ and about $3.0 \mathrm{~cm}$ per year, but it is nearly all available for recharge. Small amounts of melt water may move to the "freezing" zones of the ice sheet bed, and some melt water may be forced to the edge of the ice sheet where it can escape.

Under non-glacial conditions in this part of North America, the surface may be frozen for appreciable parts of the year and may be completely dry during other periods. Furthermore, evaporation and temperature gradients in the surface layers may also cause moisture loss. Hence, although the total annual precipitation now greatly exceeds $3 \mathrm{~cm}$, the recharge may be greater under glacial conditions because of all-year recharge and the surface pressure conditions.

Sugden's model of the Laurentide ice sheet gives a continuous frozen zone that is several hundred kilometers broad. The CLIMAP model shows sporadic frozen patches, based on the glacial geology rather than on calculations. However, as the ice sheet varies in size, all sub-glacial areas will be covered by melting ice. 
The possibility exists that recharge water under the central part of the ice sheet will be forced to move to appreciable depths. It might then flow under the frozen zone and return to the surface near the edge of the ice sheet, where the surface pressures are low (McGinnis, 1968). Other factors being equal, it seems unwise to site a nuclear waste repository (even at great depth) in an area likely to be glaciated.

Beneath the sliding parts of the ice sheet, all of the regolith and underlying permeable rock must have been saturated (Weertman, 1966). The planing of the Canadian Shield and the gouging-out of the Great Lakes indicate that sliding (and, therefore, saturation of underlying materials) has occurred for appreciable parts of each glacial cycle.

These considerations of deep recharge under the ice sheet are not likely to affect Gulf Coast and New Mexico sites because of their isolation from the ice. However, under extreme mountain glaciation conditions, or with a more extensive Cordilleran ice sheet, the Hanford Site could be in an area affected by upward movement of deep recharge waters near the ice edge.

POTENTIAL FOR AND CONSEQUENCES OF FRESH WATER FUMAROLES ASSOCIATED WITH ICE LOADING

Other than the discharge of deep recharge water near an ice sheet edge because of strong horizontal gradients of surface hydrostatic pressure, no real possibility seems to exist that glacial-related, fresh water fumarolic action will be important in waste disposal site considerations.

\section{FLOOD EROSION MAGNITUDES, RATES AND DURATIONS}

During variations in the lateral extent of an ice sheet and its lobes, floods causing extensive erosion can be caused by the release of 1 arge trapped bodies of water. Large lakes can be formed by blocking normal outlets with a lobe of an ice sheet or a mountain glacier. Subglacial lakes can be formed in existing basins (e.g., Lake Erie) and can be suddenly discharged as the edge of the ice sheet retreats to a critical point.

Extensive lobes of an ice sheet may be generated around its periphery by changes in the basal thermal conditions (Weertman, 1966). 
The Superior and Des Moines lobes of the Laurentide ice sheet (Wright and Matsch, 1973) were probably formed in this way, as a previously frozen area of the ice sheet bed to the north melted. The Des Moines lobe extended several hundred kilometers to the south but may only have occupied its forward position for a few thousand years. Thus, there may have been several earlier "Des Moines lobes" during the Wisconsin glaciation. Lakes of the Missoula type, which were trapped and released as the eastern Washington lobe advanced and retreated, as reported by $D$. Tubbs in a Battelle Workshop, may have caused a dozen Missoula floods in a period of 100,000 years during the Wisconsin stage.

Similarly, sub-glacial Great Lakes could have discharged catastrophically. Kennett and Shackleton (1975) interpret the oxygen isotope anomalies in the Gulf of Mexico sedimemt core samples "as representing the massive inpouring of glacial melt water...via the Mississippi...during the early melting phases of the late Wisconsin Laurentide ice sheet" between 12,000 and 16,000 years ago. Large ancient river channels associated with the Mississippi River system are direct evidence of southward melt water transport to the Gulf of Mexico ( $\mathrm{Clark}$ and Stearn, 1968). As the ice sheet retreated, melt water could flow eastward. Much of the erosion of the Mohawk Valley is probably due to glacial melt water, though the valley may have served as a discharge course repeatedly during the last million years.

The quantity of water discharging into the Gulf of Mexico in that period should be calculable from the changes in salinity and oxygen ratios from the sediment core samples (Kennett and Shackleton, 1975; Emiliani et a1., 1975). Similar calculations are possible based on assumed ablation rates on the ice sheet itself.

In future glaciations melt-water rivers generally will follow preexisting river courses. With specific sites it should be possible to assess the possibilities of river erosion. Some salt dome sites in the Gulf Coast region could be susceptible to changes in the course of the Mississippi River. The New Mexico site, which is on a high plateau, seems to be immune from this type of problem. The Hanford Site is only a few miles from the Columbia River, and it was probably flooded repeatedly by Missoula floods 
during the Wisconsin glaciation. In the future, lateral erosion by the Columbia River could cause changes in its course, possibly affecting the integrity of a repository at the Hanford site.

ISOSTATIC REBOUND RATES: POTENTIAL FOR AND MAGNITUDE OF FRACTURING

A thorough study of the deformation of the Earth's crust under superimposed loads has been made by Brotchie and Silvester (1969). Their earth model is a uniform, elastic, spherical shell enclosing a viscous liquid. With a crust $37 \mathrm{~m}$ thick and reasonable elastic constants, Brotchie and Silvester calculate stresses and deflections from an ice sheet of central thickness 3000 meters and radius 1450 kilometers, approximating a thin Laurentide ice sheet. Their values are as follows:

TABLE IV-1. Stress and Deflections from an Ice Sheet

\begin{tabular}{|c|c|c|c|c|c|c|c|c|c|c|}
\hline Distance from center, $\mathrm{km}$ & 0 & 290 & 580 & 870 & 1160 & 1450 & 1500 & 1600 & 1700 & $\underline{1800}$ \\
\hline Deflection, meters & 801.93 & 769.12 & 673.00 & 512.76 & 288.06 & 22.60 & 3.74 & -3.86 & -1.07 & 0.11 \\
\hline $\begin{array}{l}\text { Flexural stress, radial, } \\
\mathrm{Nm}^{-2} \times 10^{-3}\end{array}$ & -1627 & -1479 & -1503 & -1483 & -1988 & 10,300 & 7883 & 1231 & -402 & -180 \\
\hline $\begin{array}{l}\text { Flexural stress, tangential } \\
\mathrm{Nin}^{-2} \times 10^{-3}\end{array}$ & -1627 & -1495 & -1500 & -1495 & -1620 & 1486 & 1326 & 263 & -59 & -33 \\
\hline $\begin{array}{l}\text { Shear stress, } \\
\qquad \mathrm{Nm}^{-2} \times 10^{-3}\end{array}$ & 0 & 16 & 9 & 8 & -31 & 104 & -684 & -356 & -14 & 26 \\
\hline
\end{tabular}

Brotchie and Silvester (1969) state that "the corresponding stresses appear to be sufficient to cause surface cracking." Peltier and Andrews (1976) calculate the world-wide response to a distribution of ice sheets and obtain results in agreement with observed sea-level changes. Weertman (1978) analyzes the stresses that would be obtained for a "creep law" mantle. Although his approach differs from Brotchie and Silvester's "power law" approach, Weertman still obtains stresses of 30 - 300 bars.

Stresses are greatest at the edge of the ice sheet. Both the radial and tangential stresses appear sufficient to give fracturing. Fracturing, thus caused, may be responsible for the initiation of the Great Lakes and other lakes marginal to the Laurentide ice sheet. Some of these lakes are radial to 
the ice sheet, and others are tangential. Faults along the coast of Maine, probably initiated by ice-sheet margin stresses, are still active because of isostatic rebound (Rand and Gerber, 1976).

Fracturing is most likely to occur in zones previously weakened, so that new ice sheets may not cause new fracturing patterns. Nevertheless, it seems wise to avoid siting waste repositories in areas likely to be covered by ice sheets. Changes in load caused by sea-level variations in the Gulf of Mexico seem unlikely to produce stresses sufficient to cause fracturing in the northern Gulf Coast region.

\section{CONTINENTAL ICE MELTING - RIVERS OF LIMITED DURATION}

With reasonable assumptions of the ice front in future glaciations and of the crustal tilting from ice loading, it should be possible to map likely courses of major rivers produced by melting ice. Unless ice extends very much further south than in the Kansan stage, it seems unlikely that any new major valleys will be cut (Clark and Stearn, 1968). Specific potential sites in the Gulf Coast region need careful attention from this point of view. Sites on plateaus in New Mexico seem immune.

CORRELATION OF CONTINENTAL GLACIATION EPISODES TO HARMONIC ANALYSIS OR "MILANKOVITCH" STUDIES

T. Hughes reported at the Columbus Glaciology Workshop that none of the CLIMAP studies had shown a significant change in solar radiation in high latitudes from the 95,000-year obliquity perturbation. This has also been reported by $A$. L. Berger and presented by M. Schwartz at the Battelle Workshop. The 100,000-year periodicity in the oxygen-isotope record is the dominant one for the last 300,000 or 600,000 years (Hays et a1., 1976) but perhaps not further into the past. The obliquity perturbations might be the trigger for some other mechanisms affecting earth climate, including periodic world-wide vol canic eruptions.

Weertman (1976) has developed an ice-sheet generation model which responds to Milankovitch variations, but which needs a higher accumulation rate than seems consistent with the current atmospheric circulation models for glacial conditions. (Gates, 1976; Williams et al., 1974). 
Although the causes of ice ages are not known, a prudent assumption in the WISAP study is that the present interglacial will continue for only a limited period, perhaps 4000 years, and that subsequently an ice sheet, at least equal in size to the Wisconsin Laurentide ice sheet, will form over North America.

\section{REFERENCES}

Berger, A. L. In press (a). "Long Term Variations of Daily Insolation and Quaternary Climatic Changes." Journal of Atmospheric Sciences.

Berger, A. L. In press (b). "A Contribution to a Global Theoretical Model of Paleoclimates Based on the Long-Term Variations of the Earth's Orbital Elements." Quaternary Research.

Broecker, W. 1975. "Climatic Change; Are We on the Brink of a Pronounced Global Warming?" Science 189:460-463.

Brotchie, J. F. and R. Silvester. 1969. "On Crustal Flexure." Journal of Geophysical Research 74:5240-5252.

Budd, W. F. 1975. "A First Simple Model for Periodically Self-Surging Glaciers." Journal of Glaciology 14:3-21.

Budyko, M. I. 1978. "The Heat Balance of the Earth." In Climatic Change. ed. J. Gribben, pp. 85-113.

Calkin, P. E., R. H. Behling and C. Bull. 1970. "Glacial History of Wright Valley, Antarctica." Antarctic Journal of the U.S. 22-27.

Clark, T. H. and C.W. Stearn. 1968. "Geological Evolution of North America," Ronald, New York.

CLIMAP Project Members. 1976. "The Surface of the Ice-Age Earth." Science $191: 1131-1137$.

Drewry, D. J. 1976. "Deep-sea Drilling from the Glomar Challenger in the Southern Ocean." Polar Record 18:47-77.

Emiliani, C. et al. 1975. "Paleoclimatological Analysis of Late Quaternary Cores from the Northeast Gulf of Mexico." Science 189:1083-1088.

Flint, R. F. 1971. Glacial and Quaternary Geology. John Wiley and Sons, New York, NY.

Gates, L. 1976. "Modelling The Ice Age Climate." Science 191:1138-1140. 
Gow, A. J. and T. Williamson. 1971. "Volcanic Ash in the Antarctic Ice Sheet and Its Possible Climatic Implications." Earth and Planetary Science Letters $13: 210-218$.

Hammer, C. U. 1977. "Past Volcanism Revealed by Greenland Ice Sheet Impurities." Nature 270:482-486.

Hays, J. D., J. Imbrie and N. J. Shackleton. "Variations in the Earth's Orbit: Pacemaker of the Ice Ages." Science 194:1121-1132.

Hollin, J. T. 1962. "On the Glacial History of Antarctica." Journal of Glaciology $4: 173-195$.

Hollin, J. T. 1977. "Thames Interglacial Sites, Ipswichian Sea Levels and Antarctic Ice Surges." Boreas 6:33-52.

Kellogg, W. W. 1978. "Global Influences of Mankind on Climate." In Climatic Change, ed. J. Gribben, pp. 205-227.

Kennett, J. P. and N. J. Shackleton. 1975. "Laurentide Ice Sheet Melt Water Recorded in Gulf of Mexico Deep Sea Cores." Science 188:147-150.

Mathews, W. H. 1975. "Cenozoic Erosion and Erosion Surfaces of Eastern North America." American Journal of Science 275:818-824.

Mayewski, P. 1975. Glacial Geology and Late Cenozoic History of the Transantarctic Mountains, Antarctica. Report 56, Institute of Polar Studies, Ohio State University, Columbus, $\mathrm{OH}$.

McGinnis, L. D. 1968. "Glaciation As a Possible Cause of Mineral Deposition." Economic Geology 63:390-400.

Mercer, J. H. 1978. "West Antarctica Ice Sheet and $\mathrm{CO}_{2}$ Greenhouse Effect: A Threat of Disaster." Nature 271:321-325.

Nye, J. F. 1976. "Water Flow in Glaciers: Jokulhaups, Tunnels and Veins." Journal of Glaciology 17:181-207.

Peltier, W. R. and J. T. Andrews. 1976. Glacial-Isostatic Adjustment - I. The Forward Problem. Geophysical Journal of Royal Astronomical Society $46: 605-646$.

Rand, J. R. and R. G. Gerber. 1976. Sears Island Fault Investigation, Searsport, Main. Report to Maine Nuclear Power Station, Central Main Power Company, Augusta, Maine.

Ruddiman, W. F. 1977. "Late Quaternary Deposition of Ice-Rafted Sand in the Subpolar North Atlantic (1at. $40^{\circ}$ to $65^{\circ} \mathrm{N}$ )." Bulletin of the Geological Society of America 88:1813-1827. 
Shackleton, N. J. and N. D. Opdyke. 1973. "Oxygen Isotope and Paleomagnetic Stratigraphy of Equatorial Pacific Core V 28-238: 0xygen Isotope Temperatures and Ice Volumes on a $10^{5}$ and $10^{6}$ Year Scale." Quaternary Research 3:39-55.

Shack leton, N. J. and R. K. Matthews. 1977. "Oxygen Isotope Stratigraphy of Late Pleistocene Coral Terraces in Barbados." Nature 268:618-620.

Stuiver, M., I. C. Yang and G. H. Denton. 1976. "Permafrost Oxygen-Isotope Ratios and Chronology of Three Cores from Antarctica." Nature 261:547-550.

Sugden, D. E. 1976. "A Case Against Deep Erosion of Shields by Ice Sheets." Geology 4:580-582.

Sugden, D. E. 1977. "Reconstruction of the Morphology, Dynamics and Thermal Characteristics of the Laurentide Ice Sheet at Its Maximum." Arctic and Alpine Research 9:21-47.

Thompson, L. G., W. L. Hamilton and C. Bul1. 1975. "Climatological Implications of Microparticle Concentrations in the Ice Core from "Byrd" Station, Western Antarctica." Journal of Glaciology 14:433-444.

Weertman, J. 1964. "Rate of Growth or Shrinkage of Non-Equilibrium Ice Sheets." Journal of Glaciology 5:145-158.

Weertman, J. H. 1966. "Effect of a Basal Water Layer on the Dimensions of Ice Sheets." Journal of Glaciology 6:191-207.

Weertman, H. 1976. "On Milankovitch Solar Radiation and Variations in Ice Sheet Sizes." Nature 261:17-20.

Weertman, J. 1978. "Creep Laws for the Mantle of the Earth." Philosophical Transactions, Royal Society of London 288A:9-26.

Whillans, I. M. 1978. "Erosion of Continental Ice Sheets." Geology.

Whillans, I. M. In press. "Inland Ice Sheet Thinning Due to Holocene Warmth." Science.

White, W. A. 1972. "Deep Erosion by Continental Ice Sheets." Bulletin of the Geological Society of America 83:1037-1056.

Williams, J., R. G. Barry and W. M. Washington. 1974. "Simulations of the Atmospheric Circulation, Using the NCAR Global Circulation Model, with Ice Age Boundary Conditions." Journal of Applied Meteorology 13:305-317.

Wilson, A. T. 1964. "Origin of Ice Ages: An Ice Shelf Theory for Pleistocene Glaciation." Nature 201:147-149.

Wright, H. E. and C. Matsch. 1973. "The Superior and Des Moines Lobes in the Wisconinan Stage." Geological Society of America Memoir 136:153-185. 



\section{CHAPTER $V$}

\section{GEOLOGIC FAGTORS IN THE ISOLATION OF NUCLEAR WASTE: EVALUATION OF LONG-TERM GEOMORPHIC PROCESSES AND EVENTS}

\section{S. J. Mara}

\section{Stanford Research Institute}

In this report the rate, duration, and magnitude of changes from geomorphic processes and events in the Southwest and the Gulf Coast over the next million years are projected. The projections were made by reviewing the pertinent literature; evaluating the geomorphic history of each region, especially that during the Quaternary Period; identifying the geomorphic processes and events likely to be significant in the two regions of interest; and estimating the average and worst-case conditions expected over the next miliion years. The results of the analys is are presented in Table $\mathrm{V}-1$.

\section{DESCRIPTION OF THE STUDY AREAS}

\section{Existing Geomorphic Environment}

\section{Gulf Coast}

The Gulf Coast, which is within the Coastal Plains Physiographic Province, is characterized by rolling uplands with young to mature coastal plains. The flood plain and delta of the Mississippi River are the major geomorphic features of the area.

\section{Southwest}

The Southwest area extends over four physiographic provinces: Basin and Range, Colorado Plateau, Southern Rocky Mountains, and Great Plains. The Basin and Range Province (Nevada, western Utah, southern Arizona, and New Mexico) is characterized by dissected fault-block mountains with associated large alluvial fans and bajadas. The Colorado Plateau (eastern Utah, northern Arizona, northwestern New Mexico) is generally a well-dissected structural 
TABLE V-1. Summary of Projected Rates for Geomorphic Processes

\begin{tabular}{cc}
\multicolumn{2}{c}{ Rate } \\
\hline Average & Maximum \\
(m/10 $\left.{ }^{3} \mathrm{yr}\right)$ & $\left(\mathrm{m} / 10^{3} \mathrm{yr}\right)$ \\
\hline
\end{tabular}

$\begin{array}{lc}\text { Total Erosion } \\ \text { after } & 106 \mathrm{yr} \\ \begin{array}{cc}\text { Average } & \text { Maximum } \\ \text { (m) } & (\mathrm{m}) \\ \hline\end{array}\end{array}$

Denudation
Gulf
Southwest
Entrenchment
Gulf Coast

0.05

0.15

50

150

0.10

0.30

100

300

Mississippi River near mouth

$200 \mathrm{~km}$ upstream

Southwest ${ }^{\text {(d) }}$

Ashfalls (e)

Gulf Coast $(f)$

Southwest $(f)$

$\begin{array}{rccc}{ }_{50}(\mathrm{a}) & { }_{75}(\mathrm{~b}) & 100^{(\mathrm{c})} & 150^{(\mathrm{c})} \\ 6^{(\mathrm{a})} & { }^{\left(0^{(b)}\right.} & 30^{(\mathrm{c})} & 40^{(\mathrm{c})} \\ 0.20 & 1.0 & 200 & 1,000 \\ & & & \\ \times 101 & \times 102 & \text { Unknown } & \text { Unknown } \\ \mathrm{x} 102 & \mathrm{x} 103 & \text { Unknown } & \text { Unknown }\end{array}$

(a) Assumes 5,000 years for entrenchment period.

(b) Assumes 2,000 years for entrenchment period.

(c) Erosion occurring during each full glacial period. A period of aggradation follows entrenchment and tends to replace the removed sediment.

(d) Assumes uplift comparable to Late Mesozoic.

(e) Other catastrophic events considered were landslides and floods.

(f) These figures represent the order-of-magnitude increases in denudation expected.

plateau. The Southern Rocky Mountain Province in north-central New Mexico has steep, precipitous mountains (Sangre de Cristo Range) and open, grassy valleys (San Luis Valley). The Great Plains in eastern New Mexico are comprised of rolling hills and high plateaus with some entrenched streams. The Colorado is the major river basin in the Southwest. 


\section{Quaternary Geomorphic History}

Significant geomorphic changes have occurred during the Quaternary Period $(1,800,000$ years B.P. to present). The changes have been reviewed to provide a basis for predicting future conditions.

\section{Gulf Coast}

Widespread Pleistocene glaciation was accompanied by a eustatic fall in sea level that led to entrenchment and valley deepening of the Mississippi River near the Gulf of Mexico. The maxiumum depth of entrenchment probably was approximately $120 \mathrm{~m}$.

Maximum aggradation of the Lower Mississippi Valley occurred in the waning stages of the last Wisconsin glaciation and lasted no more than a few thousand years. The Mississippi River altered from braided to meandering when the ratio of sediment to water decreased sufficiently to begin degradation. The deltaic plain of the Mississippi River was structurally active during the Quaternary.

During the Holocene $(10,000$ years B.P. to present), little change has occurred in the Lower Mississippi Valley. Deltaic deposition in Louisiana occurred as the sea level rose. In the last few thousand years, the Mississippi River has continued slowly to aggrade its flood plain and to build its delta across the continental shelf.

\section{Southwest}

Tectonism and volcanism resulting from movements of crustal and oceanic plates continued into the Quaternary. The Colorado Plateau was uplifted nearly 1,500 m during the late Tertiary and early Quaternary, and some uplift of the Colorado Plateau is still occurring. In the Basin and Range Province, normal faulting and volcanism, which began in the Tertiary, continued into the Quaternary. However, volcanism in the western United States appears to have been less intense in the late Pleistocene than during the late Tertiary and early Pleistocene.

The major geomorphic feature in the Southwest is the Grand Canyon. The canyon has had a complex history of uplift, downcutting, and volcanism that began sometime in the Tertiary. 
PROBLEM FORMULATION

Geomorphic processes are influenced by many variables. Geomorphologists tend to evaluate these processes and variables over periods that are generally less than 100 years. Little research has addressed the problems associated with estimating long-term erosion and landform development.

Given the number of variables contributing to the development of 1 andforms over time, the paucity of the research is not surprising. However, the key element to remember is time. When the time frame is expanded, the number of independent variables is reduced. For example, when the time frame is expanded from 10 years to 1,000 years, the number of independent variables is reduced from seven to four.

Because the number of independent variables is reduced as the time frame expands, somewhat cruder measures can be used in place of specific analytical measurements to represent long-term, basin-wide changes in morphology. Denudation rates are one such measure. Commonly presented as the number of meters a basin is lowered in a one thousand-year period, denudation rates afford a reasonable long-term estimate that tends to smooth out pulses in the system.

\section{LONG-TERM ESTIMATES OF CONTINUOUS GEOMORPHIC PROCESSES}

\section{Denudation}

At any given time, a basin is undergoing net storage or flushing of sediment. For example, sediment will be stored until a geomorphic threshold is passed; at that time erosion (or flushing) begins. Consequently, erosion rates represent a normal, yet unstable period, in the history of a basin. Denudation, on the other hand, occurs over longer periods, and this lengthy duration tends to even out short-term anomalies. Although in some cases man has increased rates of erosion by a factor of seven or eight since European settlement, denudation rates that are based on data gathered in the last 100 years should provide a reasonable compromise between short-term ( $<100$ years) erosion in localized areas and long-term (>1,000 years) evaluation of a drainage basin. 
Calculations of denudation rates are usually based on data obtained from the dissolved and suspended sediment load of streams. Climate and tectonic environment have a significant influence on the estimated rates; for example, the Kosi River Basin, which receives sediment eroded from Mt. Everest, has an estimated denudation rate 20 times higher than that estimated for the Gulf Coast.

Maximum denudation rates occur when effective precipitation ranges from 25-38 cm. Maximum rates are therefore expected in the Southwest, where effective precipitation ranges from $20-30 \mathrm{~cm}$. However, the Gulf Coast's effective precipitation ranges from $63-127 \mathrm{~cm}$, indicating that estimated denudation rates should be lower there.

Although the Southwest and the Gulf Coast have tectonically active areas, the associated rates of uplift and subsidence are very slow. From the data available, it appears clear that uplift and isostasy are much faster than denudation. Therefore, to evaluate a worst case, denudation could be assumed to equal uplift (or subsidence). Estimates of maximum and average denudation rates have been made. These estimates assume that any uplift or subsidence that occurs will be quite slow.

\section{Entrenchment}

In addition to overall lowering of the basins by denudation, entrenchment of streams is another possible mechanism that could result in a breach of the geologic containment. Entrenchment is the process by which streams cut through geologic materials.

\section{Gulf Coast}

A simple way to estimate maximum entrenchment rates for the Mississippi River or other coastal streams is to assume that entrenchment will keep pace with lowering of sea level during a glacial period. Estimates of the maximum lowering of sea level during the Pleistocene full glacial intervals vary from 80-140 m. The coastline during a full glacial interview, however, would be several hundred kilometers south of its present location. For a worst case, entrenchment at the present mouth of the Mississippi River could be assumed to equal maximum sea-level lowering. Rates are estimated by assuming that a 
full-glacial interval will last from 10,000 to 20,000 years, and that maximum entrenchment (coinciding with maximum sea-level lowering) will occur over a period of 5,000 years or less.

Southwest

The Colorado River provides a dramatic example of entrenchment where it flows through the Grand Canyon. Rates of downcutting have ranged from a high of $0.3 \mathrm{~m} / 10^{3}$ years during the Pliocene to a low of $0.01 \mathrm{~m} / 10^{3}$ years at present. Although these rates are much slower than those estimated for the Gulf Coast during a full glacial interval, it must be remembered that the duration of downcutting in the Grand Canyon extends over several million years rather than over several thousand years as in the former case.

Aggradation

\section{$\underline{\text { Gulf Coast }}$}

The alluvial valley of the lower Mississippi is a broad lowland varying from 40 to $200 \mathrm{~km}$ in width. More than $100 \mathrm{~m}$ of alluvium has been deposited in some parts of the valley. Rates of aggradation in large part depend on rates of sea-level rising. During the most rapid phase of deglaciation, from about 10,000-7,000 years B.P., sea level may have risen at a rate of $1 \mathrm{~cm} /$ year.

A simple way to account for aggradation in a model of a geologic system is to assume that the trenching which occurs during the simulated glacial interval is entirely compensated by deposition of alluvium during the waning stages of glaciation. Therefore, whether or not a breach in the geologic containment occurs will depend on the maximum lowering of sea level and the associated entrenchment of the river. Following entrenchment, aggradation will occur and the cycle will be repeated during the next glacial interval. No evidence exists to suggest that aggradation following entrenchment results in a net lowering of the river valley over and above that accomplished by denudation. However, if uplift operates concurrently with entrenchment, net lowering could occur.

\section{Southwest}

Aggradation similar to that associated with periglacial environments is not expected to occur in the Southwest within the next million years. 
However, aggradation in the form of alluvial fans will occur. Although alluvial fans and bajadas (coalescing fans) are important local geomorphic features, they are not expected to affect estimated rates of denudation and entrenchment substantially. Therefore, aggradation in the Southwest need not be included in the simulation model.

\section{LONG-TERM ESTIMATES OF CATASTROPHIC EVENTS}

Landslides

Mass movement in the form of landslides is an important mechanism in the weathering process in certain regions of the United States. Although small localized landslides, primarily earth slides, may occur in the Gulf Coast, no major landslides are expected to occur in that region in the next one million years. The Southwest, however, has known occurrences of fairly large landslides, especially debris flows.

Although a landslide releases significant energy, most of the energy is absorbed in breaking up the mass of material. No known cases exist of a landslide triggering seismic activity.

Landslides do not account for substantially larger volumes of sediment than do normal rates of denudation. The author recommends that landslides not be included in the long-term simulation model.

Flooding

Catastrophic floods have been responsible for rapid movement of large volumes of sediment. The erosive power of such events greatly supersedes that of 1 andslides.

There are no known cases of catastrophic flooding in the Gulf Coast or the Southwest. Although the catastrophic release of Lake Bonneville occurred close to the area of study, existing and probably future drainage conditions make it highly unlikely that flooding to the south will occur. Volcanic activity in portions of northern Arizona and New Mexico could conceivably initiate small-scale catastrophic flooding during a glacial period; however, the overall erosive effect would be minimal. Therefore, the potential for a catastrophic flood in the areas of study during the next million years is remote and should not be included in the long-term simulation model. 
Ashfall

Ashfall may result from widespread (or long-term) volcanic activity and may denude the landscape. Erosion rates would be affected by two factors: removal of vegetation and changes in the characteristics of the top layer of erosive material.

Removal of vegetation has been shown repeatedly to increase erosion significantly by reducing infiltration, by increasing runoff velocity and volume, and by decreasing land surface stability. The deposition of a layer of ash on the land surface, however, could have a countering effect. The ash may impart special properties of superior strength and chemical resistance that significantly reduce its ability to erode. Nevertheless, where slopes are moderately steep and precipitation occurs in intense, convectional storms (as in a semiarid climate), sheet wash erosion and gullying would take place. A worst case would occur if the ash was assumed to have no counterbalancing effect on the denudation of vegetation. In that case, erosion rates in the Southwest could be expected to increase by as many as three orders of magnitude, whereas rates in the Gulf Coast would increase by as many as two orders of magnitude. 
CHAPTER VI

LONG-TERM METEORITE HAZARDS TO BURIED NUCLEAR WASTE

Report 2

W. K. Hartmann

Planetary Sciences Institute

SUMMARY

The main purpose of this study is to put into analytic form information on the frequency of meteorite impact events 1 arge enough to affect buried nuclear wastes. Part 1 presents new data on the relation between crater size and total impact energy, with equation (1) expressing the relation. Part 2 derives equation (6), which gives the rate of accumulation of area covered by craters larger than diameter $D$. A graphical relation between $D$ and the depth of disturbance (Figure $V I-2$ ) is given. This section concludes that the probability of a single site $600 \mathrm{~m}$ deep being disturbed in a million years is of the order $2.5 \times 10^{-6}$. Part 4 points out that meteorite impacts are also sources of seismic disturbance and should be factored into the seismic model for the hazard study. Equation (8) gives a methodology for including meteorite impacts in the seismic model. Part 5 and equation (9) give a methodology for dealing with repositories with extended surface area. Part 6 gives examples of applications.

\section{RELATION BETWEEN CRATER SIZE AND TOTAL ENERGY}

Figure VI-1 shows the relationship between crater size and energy of an incoming meteorite. New information on this subject has come from several sources. In September 1976, a major symposium on "Planetary Cratering Mechanics" was held in Flagstaff, and the results were published in 1978 (Roddy et a1., 1978). Several papers, especially Croft (1978) and Vortman (1978) discuss the energy needed to produce a terrestrial crater of certain 


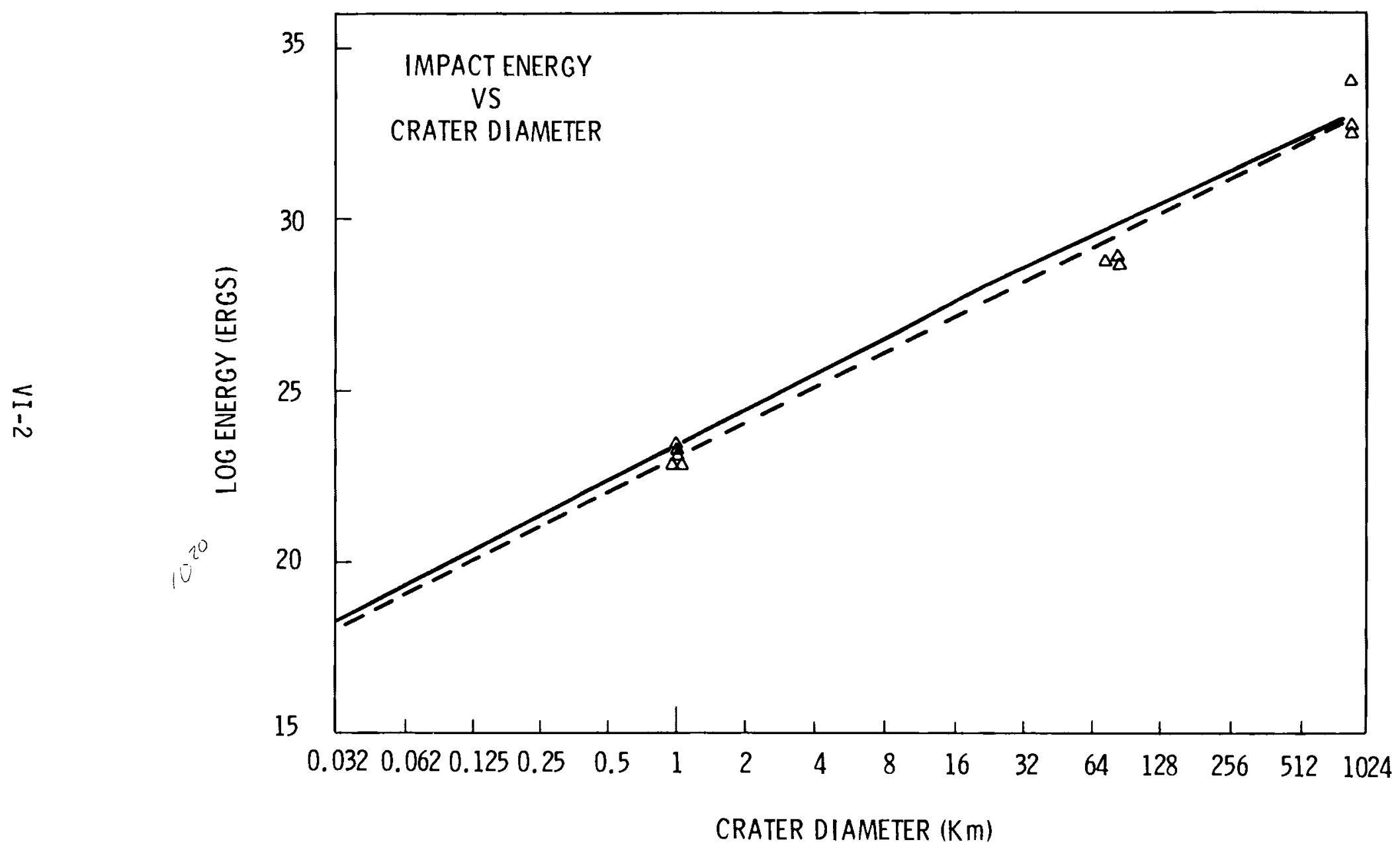

FIGURE VI-1. Relation of Total Kinetic Energv of Meteorite on Impact with Diameter of Resulting Crater. Solid line gives equations developed by Baldwin (1963). $X_{s}$ give estimates for different-sized craters in recent summary by Croft (1978). Dashed line is analytic equation developed here (Equation 1). 
size. A review of the material indicates that there is a significant spread in estimated total kinetic energy required to produce an impact crater of certain size, partly because most empirical data on large craters come from explosions of different types rather than impacts.

The solid line in Figure VI-1 shows the curves derived in previous work, based on Baldwin (1963), and the $x$ 's in Figure VI-1 show the recent estimates of total energy expended to make craters of several sizes, based on Croft (1978). The average of Croft's and Baldwin's figures tend to be a factor of about 2 or 3 less than the results of Baldwin.

A purpose of this report is to put relevant meteorite data into a simple analytical form for use in a computer model for release scenario analysis. An adequate fit to the new data (as well as the old data) in Figure VI-1 is given by:

$$
\log D=0.288 \log K E-6.637
$$

where

$$
\begin{aligned}
D & =\text { crater diameter }(\mathrm{km}) \\
K E & =\text { total kinetic energy of meteorite at impact (ergs) }
\end{aligned}
$$

Check: Using the diameter of Meteor Crater, Arizona, $1.04 \mathrm{~km}$, the equation yields $\log K E=23.1$. This figure is in the range of energy currently estimated for that event, as summarized by Croft (1978).

\section{DERIVATION OF ANALYTIC TREATMENT OF CRATERING HAZARD}

Both terrestrial and lunar craters have been used to derive crater production rates. The lunar craters are easier to use because they offer more complete statistics, being we11-preserved in the $3.5 \times 10^{9}$ year old lava flows of the moon. Studies indicate that the lunar and terrestrial rates are within a factor 2 of each other, an uncertainty comparable to or less than the uncertainty in the terrestrial rate. In previous work, therefore, a rough mean rate for the last $3.5 \times 10^{9}$ years was used, derived by dividing crater density on average lunar lava flows (craters $/ \mathrm{km}^{2}$ ) by the average age of the flows (in years) to get craters formed $/ \mathrm{km}^{2} / \mathrm{yr}$. 
A comparison of actual crater counts of different Apollo landing sites with the measured rock ages at these sites provides information on the rate of change of cratering rate with time. This comparison has been done with early data and, more recently, with updated data (Hartmann, 1972; Hartmann et al., in preparation). Two results are that (1) it is possible to show that the crater production rate was declining during formation of the lunar lavas, up until about $3 \times 10^{9}$ years ago, and (2) it is possible to estimate the figure applicable at the present time by fitting the lunar data to terrestrial data derived from craters in geologic provinces such as the Canadian Shield and eastern U.S., where dozens of eroded craters have been found. Thus, the time dependence can be sketched throughout a time interval from about 3.5 to less than 1 billion years ago. The results indicate that the cratering rate has been relatively constant (within a factor of perhaps 3 ) in the last 2.5 billion years, even though it was much larger earlier.

In this way it is found that impact craters larger than $4 \mathrm{~km}$ diameter are currently being formed at about a rate of

$$
N_{4}=1.5 \times 10^{-14} \text { craters of } D>4 \mathrm{~km} / \mathrm{km}^{2} / \mathrm{yr} \text {. }
$$

From the same data (craters on the lunar maria, primarily) a least squares solution of crater diameter distribution has been found to be:

$$
N=C D^{-1.80}
$$

From equations (2) and (3), we have the constant,

$$
C=1.82\left(10^{-13}\right)
$$

so that

$$
N_{D}=1.82\left(10^{-13}\right) D^{-1.80} \text { craters } / \mathrm{km}^{2} / \mathrm{yr}
$$

where

$$
N_{D}=\text { formation rate of craters of diameter }>0 \mathrm{~km} \text { (craters } / \mathrm{km}^{2} / \mathrm{yr} \text { ) }
$$


This fit is accurate within an estimated $40 \%$ or better for craters larger than $D=2 \mathrm{~km}$. Below this size, it is probably accurate for primary meteorite impact craters (those formed by meteorite impact) but neglects the secondary impact craters (formed by debris thrown out of primaries) that begin to be more numerous at sizes below about $2 \mathrm{~km}$ on the moon. For this study the curve for primaries will be used, because (1) secondaries on earth may be less numerous because of atmospheric drag effects, and (2) secondaries are of less significance at diameters above $500 \mathrm{~m}$ (which are of concern in this study) than at smaller sizes.

In the hazard evaluation program, a parameter that seems more useful than the total number of craters formed per $\mathrm{km}^{2} / \mathrm{yr}$ is the total area A covered by craters per $\mathrm{km}^{2} / \mathrm{yr}$, because the total area covered by craters determines the fractional amount of ground excavated to below a given depth. A factor that is important in determing the total area covered by craters is crater diameter. The total area covered by craters per $\mathrm{km}^{2} / \mathrm{yr}$ can be evaluated as follows. The incremental diameter frequency function is (by differentiating Equation 3):

$$
d N=-1.80 C D^{-2.8} d D
$$

Therefore the area in each increment is:

$$
\begin{aligned}
\mathrm{dA} & =\pi(D / 2)^{2} \mathrm{dN}=\frac{\pi}{4} \mathrm{D}^{2} \mathrm{dN} \\
& =-\frac{1.80 \pi C}{4} \mathrm{D}^{-0.8} \mathrm{dD}
\end{aligned}
$$


Therefore the cumulative area of craters bigger than $D$ is:

$$
\begin{aligned}
A & =\int_{\max }^{D} d A=-\frac{1.80 C}{4} \int_{D_{\max }}^{D} D^{-0.8} d D \\
& =-\frac{1.80 \pi C}{4}\left(\frac{1}{0.2}\right) \int_{D_{\max }}^{D} D^{+0.2} \\
& =1.29\left(10^{-12}\right)\left[D_{\max }+0.2-D^{+0.2}\right]
\end{aligned}
$$

The resulting number is fairly insensitive to the value chosen for $D_{\max }$, which in the case of the lunar lava plains is about $181 \mathrm{~km}$. Using this number for $D_{\max }$, we have:

$$
\begin{aligned}
A & =1.29\left(10^{-12}\right)\left[2.8-D^{+0.2}\right] \\
& =\text { area excavated by all craters larger than } D \mathrm{~km} / \mathrm{km}^{2} / \mathrm{yr} \\
& =\text { fractional area excavated } / \mathrm{yr} .
\end{aligned}
$$

Table VI-1 gives some tabular examples of the rate of area coverage by craters of different diameters $D$ and depths $d$, and shows that the results from Equation (6) are reasonably consistent with the graphical results derived in previous work.

To evaluate the probability of an impact penetrating deeper than depth d, or causing fractures to depth $d_{f}$, one simply chooses the depth with which one is concerned, determines the minimum diameter crater (D) that affects this depth, and then solves equation (6) for that D-value to get the rate at which surface area is chewed up to that depth. The relation of crater depth d, fracture depth $d_{f}$, and crater diameter $D$ is graphically shown in Figure VI-2. 
TABLE VI-1. Results from Equation (6) and Comparison with Data From Previous Work

\begin{tabular}{|c|c|c|c|c|c|}
\hline $\begin{array}{l}\text { Excavation } \\
\text { Depth (d) } \\
\qquad(\mathrm{m})\end{array}$ & $\begin{array}{l}\text { Fracture } \\
\text { Depth } \\
\left(d_{f}\right)(m)\end{array}$ & $\begin{array}{l}\text { Crater } \\
\text { Diam. } \\
\text { (D) }(\mathrm{km})\end{array}$ & $\log A$ & $\begin{array}{l}\log A \text { Value } \\
\text { from } \\
\text { Previous } \\
\text { Work }\end{array}$ & $\begin{array}{c}\text { Years Required to Cover } 60 \% \\
\text { of Area with Craters of } \\
\text { Diameter } D(=1 / A)\end{array}$ \\
\hline 10 & 40 & .05 & -11.5 & $-9.4^{(a)}$ & $3(11)$ \\
\hline 33 & 132 & .19 & -11.6 & -11.5 & $4(11)$ \\
\hline 100 & 400 & .64 & -11.6 & -11.5 & $4(11)$ \\
\hline 333 & 1332 & 2.5 & -11.7 & -11.6 & $5(11)$ \\
\hline 1,000 & 4,000 & 9.2 & -11.8 & -12.1 & $6(11)$ \\
\hline 3,333 & 13,332 & 38.7 & -12.0 & $-12.4^{(b)}$ & $1(12)$ \\
\hline 10,000 & 40,000 & 128 & -13.0 & $-12.4^{(b)}$ & $1(13)$ \\
\hline
\end{tabular}

(a) This value is considerably higher than that in the new calculation, because it takes into account the abundant secondaries, whereas the present calculation neglects them. They appear so shallow that they are not a serious part of the total hazard.

(b) These values are somewhat higher than the older values because of a difference in the diameter distribution of craters assumed in the two studies. The new distribution, based on a least squares fit to crater count data, appears more accurate. The risk is so small from these rare, 1 arge- $D$ craters that the difference appears unimportant. Agreement at other diameters is quite good. 


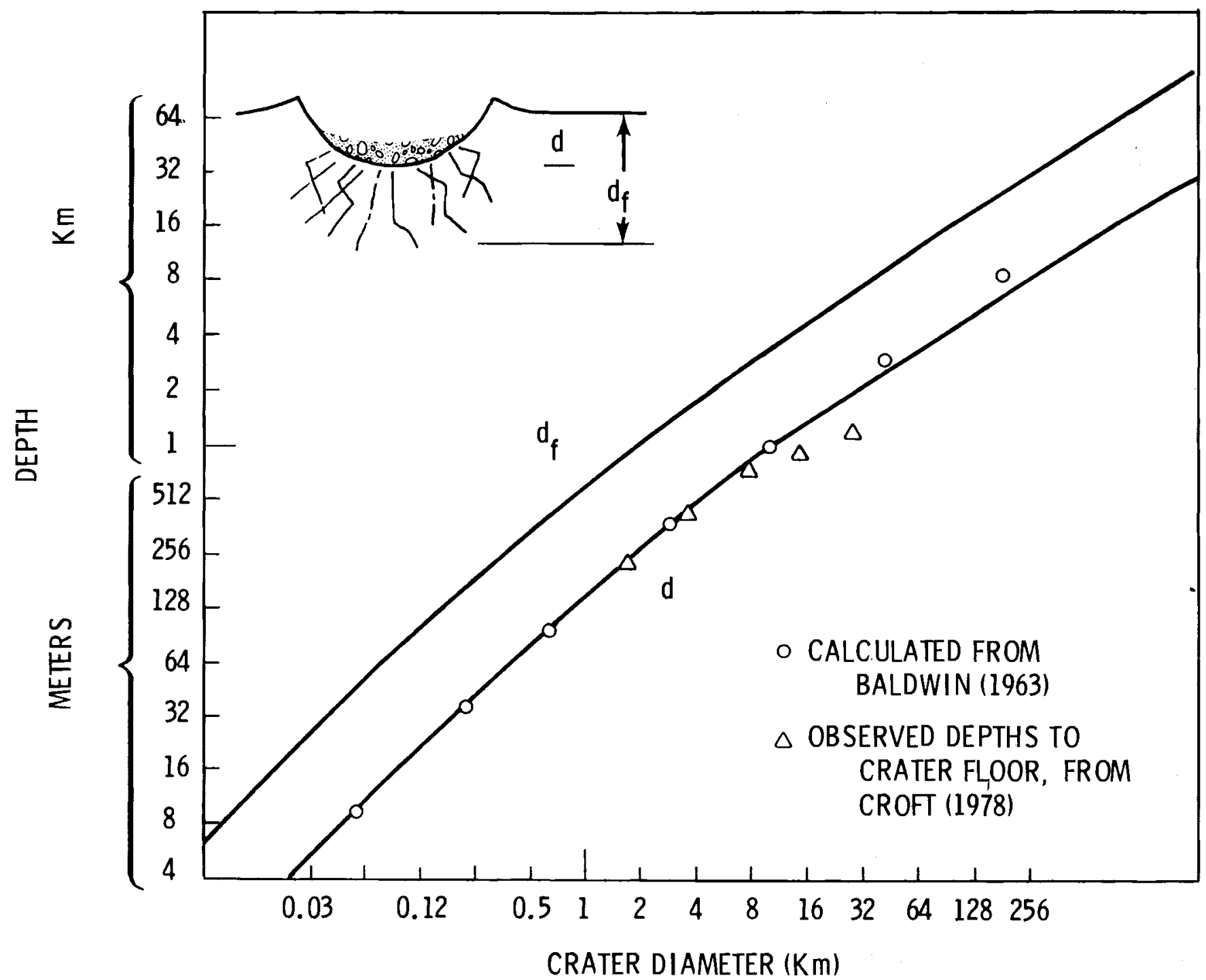

FIGURE VI-2. Relation Between Crater Diameter (D) and the Depth of Excavation (d) and the Depth of Fracturing $\left(d_{f}\right)$ 
The time required to cover any given fraction of the U.S. (or any other area) with craters larger than $D$ can be easily computed. The inverse of $A$, i.e., 1/A, gives the timescale needed to cover a large fraction (some 60\%) with craters. For example, A for $2.5 \mathrm{~km}$ craters, which excavate to $100 \mathrm{~m}$ and fracture to $400 \mathrm{~m}$, is found to be $2.06 \times 10^{-12} /$ year. One would have to wait $1 / A=5 \times 10^{11}$ years to accumulate enough area to cover most of the ground. To get a $1 \%$ chance of penetration or fracturing to the depths indicated, one would have to wait $5 \times 10^{9}$ years. Other probabilities can be similarly scaled.

Because the repository studied in the July 1977 Battelle workshop is considered to be $600 \mathrm{~m}$ deep with a proposed lifetime of $1 \mathrm{million}$ years, it is possible to estimate from equation (6) or Table VI-1 that the probability of penetration in $10^{6}$ years is about $10^{6} / 4 \times 10^{11}$, or $2.5 \times 10^{-6}$, and the time to increase the probability of penetration by fractures to near $100 \%$ would be roughly $4 \times 10^{11}$ years.

\section{NOTE ON CONSTANCY OF CRATERING RATE}

Analyses of cratering, both by empirical Apollo evidence and celestial mechanical theory of asteroid orbits, indicates that the cratering rate in the current $10^{8}$ year period is nearly constant and may be declining slightly on the long term as interplanetary debris are swept up. Although there is always a chance of some new debris being injected into our part of the solar system by perturbation of material in other regions, it appears unlikely that a strong surge of meteoritic cratering could seriously affect the hazard to nuclear wastes in the next $10^{6}$ years.

\section{METEORITE IMPACTS AS SEISMIC ENERGY SOURCES - ANALYTIC TREATMENT}

An impacting meteorite carries a certain amount of initial kinetic energy. In addition to being dissipated by crushing and accelerating rock to make the crater, this energy is partly dissipated in the form of seismic waves. Therefore, it appears appropriate to treat the meteorites not only as an excavation hazard, but as a source of seismic disturbances randomly distributed in time and space. 
There is some controversy in the cratering literature about how much energy finally dissipates in the form of seismic waves, because a certain fraction is lost in heating and crushing the target rock layers. The accelerated ejecta eventually returns to earth, so that a certain part of its kinetic energy ultimately appears as seismic waves, in addition to the seismic waves from the impact site. O'Keefe and Ahrens (1977) have recently studied the partitioning of energy during impact and have compared their results (which are essentially theoretical) with earlier small-scale experiments. They found that about $40 \%$ of the energy in high-speed ( $5 \mathrm{~km} / \mathrm{sec}$ ) impact is lost in heating of the target, compared to an earlier finding from small-scale lab impacts $(6.2 \mathrm{~km} / \mathrm{sec})$ of roughly $30 \%$. The two studies disagree on how the remaining 60-70\% of the initial energy is distributed. 0'Keefe and Ahrens suggest $50 \%$ goes into crushing or plastic deformation of rock and $10 \%$ into ejecta kinetic energy. The earlier study (Gault and Heitowit, 1963) puts these two percentages at about $15 \%$ and $55 \%$, respectively. In any case, it appears that the ultimate amount of energy dispersed as seismic waves is unlikely to be more than $30 \%$ of the initial total and may be as small as a few percent. We will take $30 \%$ as the upper bound for the purposes of the hazard study.

We therefore have:

$$
\mathrm{SE}=0.3 \mathrm{KE}
$$

where

$$
\begin{aligned}
& S E=\text { energy dispersed as seismic energy } \\
& K E=\text { initial total kinetic energy of impact. }
\end{aligned}
$$

From equation (1), we have:

$$
\log D=0.288 \log (3.33 S E)-6.637
$$

Therefore,

$$
\log D=0.288 \log S E-6.115
$$


This equation gives the seismic energy dissipated during formation of a crater of size $D$. The frequency $N$ (events $/ \mathrm{km}^{2} / \mathrm{yr}$ ) is given by equation (5) as:

$$
\begin{aligned}
\log N & =-1.80 \log D-12.74 \\
& =-1.80(0.288 \log \mathrm{SE}-6.115)-12.74 \\
& =-0.518 \log \mathrm{SE}-1.73 \\
& =\log \left(\text { no. seismic events } / \mathrm{km}^{2} / \mathrm{yr}\right)
\end{aligned}
$$

where

$$
\text { SE = energy of seismic source in ergs. }
$$

This formulation should permit meteorite impacts to be treated in the release scenario analysis as a form of earthquake with the random frequency specified by equation (8). It will admittedly be small but might be significant in geological areas that are otherwise thought to be very stable and seismically quiet.

\section{EXTENDED VS. "POINT" REPOSITORIES}

Equation (6), giving the rate at which areas are excavated to depth $d(D)$ or fractured to depth $d_{f}(D)$, was formulated to allow evaluation of meteorite hazards in the case where a repository has a surface dimension $\ll D$. In this case, such as a repository in the form of a shaft a few meters wide, the repository was viewed as a point and the question was asked, simply, how long will it take until one of the sufficiently large craters overlaps that "point?"

In the June 1978 workshop at Battelle, several participants referred to an extended repository area, perhaps encompassing over $10 \mathrm{~km}^{2}$ or more. The entire area would need to be kept free from disturbance. A breach or disturbance is assumed to occur if any part of this area is penetrated to the critical burial depth (usually taken as $600 \mathrm{~m}$ ).

In this case a new methodology is needed. Equation (6) is no longer useful, but equation (5) permits easy evaluation of the hazard. One simply selects the crater diameter $D$ viewed as constituting a threat. For example, from Figure VI-2, D must be $=6 \mathrm{~km}$ in order to excavate to $600 \mathrm{~m}$, and $D$ must 
be $=1 \mathrm{~km}$ in order to fracture to $600 \mathrm{~m}$. From equation (5), we see that the number of craters expected in a critical area $A$, during time $T\left(T=10^{6}\right.$ years in the Battelle study) is:

$$
\text { No. } \operatorname{craters}(\text { size } D)=N_{D} A T
$$

As shown in Figure VI-3, the critical area A must be calculated from the width of the repository plus a zone of width $D$, because an impact centered just outside the repository could penetrate into it.

In typical applications, the number of craters calculated in equation (9) comes out to be far less than 1. The calculated number is interpreted as a probability of breach or disturbance during time $T$.

\section{EXAMPLES}

1. What is the timescale for formation of craters larger than $D=1 \mathrm{~km}$ in North America (where impact craters have been relatively well-cataloged geological1y)?

Equation (5) gives formation rate

$$
N_{D}=1.82\left(10^{-13}\right) D^{-1.80} \text { craters } / \mathrm{km}^{2} / \mathrm{yr}
$$

Area of North America is $2.4 \times 10^{7} \mathrm{~km}^{2}=\mathrm{A}$.

Thus, No. of craters $/ y r=N_{D} A$

$$
\begin{aligned}
& =1.82\left(10^{-13}\right)(1)(2.4)\left(10^{7}\right) \\
& =4 \times 10^{-6} \text { craters } / y r
\end{aligned}
$$

This number indicates that the time required to get a high probability of one crater is about 200,000 years. North America may have two craters in this interval of time. The famous Arizona crater $(D=1.2 \mathrm{~km})$ is estimated to be roughly 20,000 years old. The New Quebec crater in Canada $(D=3.4 \mathrm{~km})$ is probably somewhat older. 


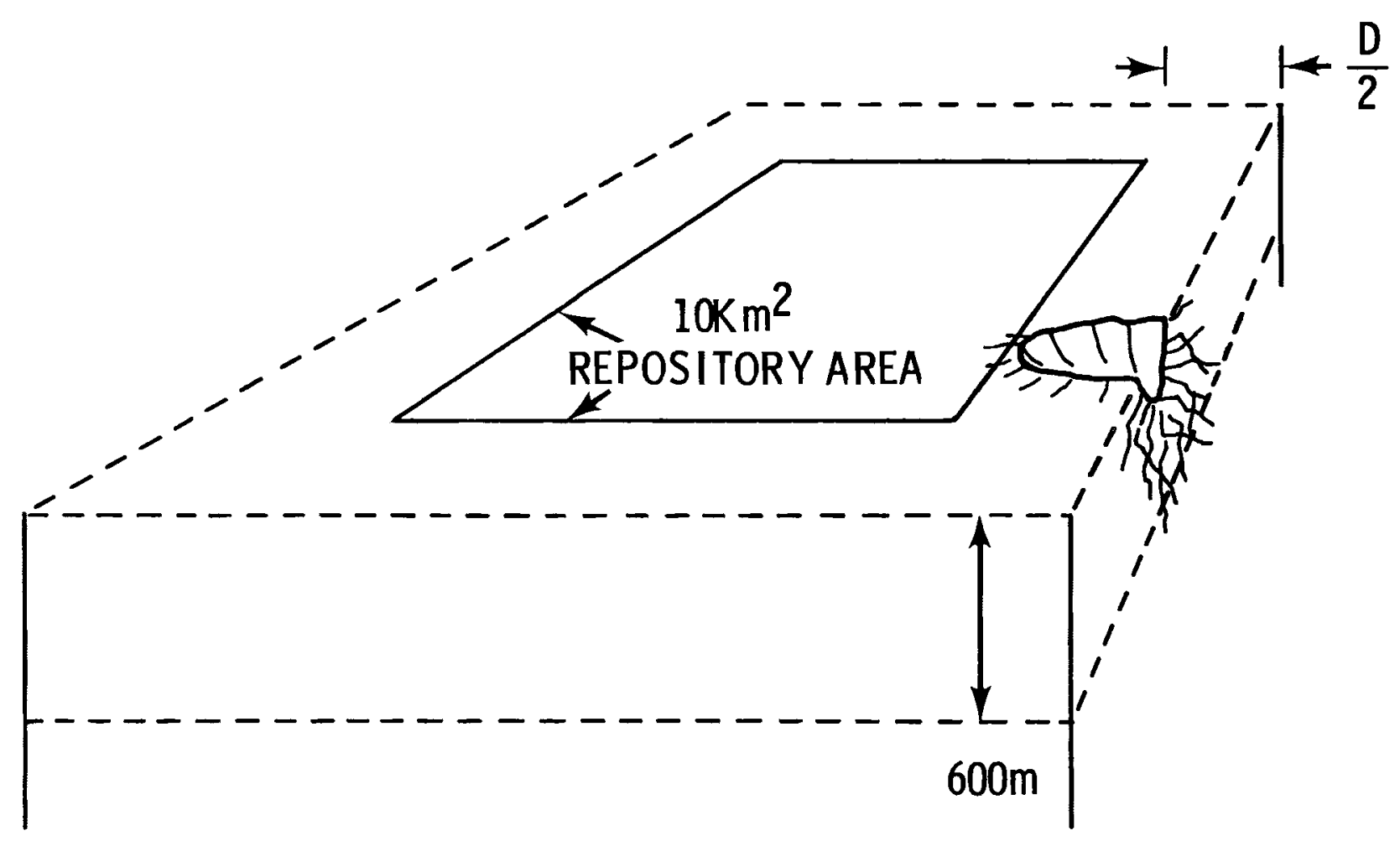

FIGURE VI-3. Sketch of Repository Surface Area (solid lines) Showing Damage Extending into Repository from an Impact Crater Lying in a Zone Just Outside Repository (dashed line). Critical area is thus given by width of repository plus a zone of $D / 2$ on each side. Impact anywhere in this larger zone, as evaluated in text, causes damage in repository if crater diameter is larger than the $D$ value specified. 
2. How many craters larger than $D=10 \mathrm{~km}$ would be expected to have formed in the Canadian Shield during the roughly $10^{9} \mathrm{yr}$ during which its surface rocks have been exposed and stable?

Area of Canadian Shield $=A=3.7 \times 10^{6} \mathrm{~km}^{2}$

Using the same formulation as above, we have

No. craters $=N_{D} A T=1.82\left(10^{-13}\right) 10^{1.80} 3.7\left(10^{6}\right)\left(10^{9}\right)=11$

Work done by M. Dence and W. K. Hartman indicates that there are actually about 10 very probable impact craters in this size range known in the Canadian Shield area. These craters are identified by circular structures and shock metamorphism indicative of impact. These craters range in diameter from 12.5 $\mathrm{km}$ (Nicholson Lake) to $70 \mathrm{~km}$ (Manicouagan), and in age from about $15 \mathrm{~m} . \mathrm{y}$. (Haughton Dome) to about $485 \mathrm{~m} . \mathrm{y}$. (Carswell Lake). The age range suggests that the true number should be more than 10, perhaps 20 , for a 1 b.y. time period.

3. What is the probability of a catastrophic impact that would completely exhume part of a repository with area of $10 \mathrm{~km}^{2}$, buried $600 \mathrm{~m}$ deep, during a 1 million year interval?

From $F$ igure VI-2, $D=6 \mathrm{~km}$ for $\mathrm{d}=600 \mathrm{~m}$

From Figure VI-3, the critical area is $(\sqrt{10}+6)^{2}=84 \mathrm{~km}^{2}$

From Equation 9,

$$
\begin{aligned}
\text { No. craters } & =N_{D} A T=1.82\left(10^{-13}\right) 6^{-1.80} 84\left(10^{6}\right) \\
& =6 \times 10^{-7}=\text { probability. }
\end{aligned}
$$

4. What is the probability of an impact that would extend fractures to the burial depth of $600 \mathrm{~m}$ occurring in a repository with area $10 \mathrm{~km}^{2}$ within 1 milition years? 
From Figure VI-2, $D=1 \mathrm{~km}$ for $d_{f}=600 \mathrm{~m}$

From Figure VI-3, the critical area is $(\sqrt{10}+1)^{2}=17 \mathrm{~km}^{2}$

From Equation 9,

$$
\begin{aligned}
\text { No. craters } & =N_{D} A T=1.82\left(10^{-13}\right) \text { (1) } 17\left(10^{6}\right) \\
& =3 \times 10^{-6}=\text { probability. }
\end{aligned}
$$

\section{REFERENCES}

Baldwin, R. B. 1963. The Measure of the Moon. Univ. of Chicago Press, Chicago, IL.

Croft, S. K. 1978. "Energies of Formation for Ejecta Blankets of Giant Impacts." In Impact and Explosion Cratering, p. 1279, Pergamon Press, New York, NY.

Gault, D. E. and E. D. Heitowit. 1963. "The Partition of Energy for Hypervelocity Impact Craters Formed in Rock." Paper presented at the Sixth Hypervelocity Impact Symposium, $\mathrm{Cleveland,} \mathrm{OH}$.

Hartmann, W. K. 1972. "Paleocratering of the Moon: Review of Post-Apollo Data." Astrophys. Space Sci. 17:48.

Hartmann, W. K. et al. (in preparation). Report for Planetary Basaltic Volcanism Study Project. Report prepared for NASA, Lunar and Planetary Institute, Houston, TX.

0'Keefe, J. D. and T. J. Ahrens. 1977. "Impact-Induced Energy Partitioning, Melting, and Vaporization on Terrestrial Planets." Proc. Lunar Science Conference, v. 8, p. 3357.

Roddy, D. J., R. Pepin, and R. Merri11. 1978. Impact and Explosion Cratering. Pergamon Press, New York, NY.

Vortman, Luke J. 1978. "Craters from Surface Explosions and Energy Dependence, A Retrospective View." In Impact and Explosion Cratering,

p. 1215. Pergamon Press, New York, NY. 



\title{
CHAPTER VII
}

PRELIMINARY SUBSURFACE HYDROLOGIC CONSIDERATIONS: COLUMBIA RIVER PLATEAU PHYSIOGRAPHIC PROVINCE

\author{
M. D. Veatch
}

Shannon and Wilson, Inc.

Subsurface hydrologic conditions in the Pacific Northwest are strongly controlled by the structural and stratigraphic framework of subregions. The subregions may encompass hundreds of square miles and are, therefore, extremely large in comparison to the underground space required for a radioactive waste repository. The groundwater storage capability of the aquifer system or systems may be relatively small within a subregion, compared to the areal extent and volume of geologic media within that subregion. These geologic media could experience a change in state-of-stress (mechanical and/or hydraulic) caused by the regional forces. These forces might be imposed by some of the identified disruptive phenomena, such as glaciation, tectonic forces, igneous intrusion, or volcanic extrusion.

A significant portion of the Pacific Northwest is underlain by the Columbia River Plateau basalt sequence. This discussion is limited to hydrologic conditions as they relate to the Columbia River Plateau physiographic province and specifically to the Pasco Basin in the central part of the province.

GENERAL GEOLOGIC AND SUBSURFACE HYDROLOGIC CONDITIONS

The Columbia River Plateau physiographic province is bounded by the Okanogan Highland to the north, the Clearwater Mountains to the east, the Blue Mountains to the south, and the Cascade Range to the west. This region is a broad structural basin. Its topographical and structural low points occur in the Pasco Basin near Pasco, Washington, in the central part of the Columbia Plateau. From the Pasco Basin, the plateau surface rises gently toward the surrounding highlands. 
The geologic history of the Columbia Plateau can be traced back about 15 million years. However, geologists can only guess what the pre-Miocene geologic history may be by studying the older rocks that disappear under the basalt flows around the edge of the plateau; no significant windows have been eroded through the Columbia River basalt sequence. The bedrock does not consist entirely of basalt. Rivers flowed out onto the flood-basalt lava plain between at least some of the volcanic eruptions. They transported and deposited sediments along their course and into shallow lakes. Therefore, layers of sedimentary rock (sedimentary interbeds) occur between lava flows. Furthermore, these interbeds are the main aquifer zones in the basalt sequence of the Pasco Basin.

Strata of Pliocene age overlie the Miocene basalt sequence. The Pliocene strata consist mainly of stream and lake sediments which contain a few interbedded basalt flows. Large-scale deformation of the region has occurred during the past 10 million years. The Columbia River basalt sequence dips away from the surrounding mountains, as a result of uplift of the ranges and sinking of the plateau. Many folds and minor faults have locally warped and, in some instances, broken the basalt flows.

The individual lava flows range in thickness from a few meters to over 50 meters. Magma eruptions were not from a single vent but from very long fissures, each of which were many miles long. Therefore, an individual eruption was probably fed by many fissures transporting basaltic magma simultaneously.

Systems of fractures cut the rock into irregular columnar, cubical, and plate-shaped blocks. These fractures and primary structures were formed when the lava was cooling. A typical Columbia River basalt flow may have taken several decades to solidify completely. In each flow the lava crystallized from the bottom up as well as from the top downward. Crystallization of a flow inward from the bottom and top surfaces produced two distinct layers in many flows. In cliff exposures these two layers have been, at a distance, misinterpreted as two distinct flows. The bottom part is known as the colonnade and the top as the entablature. These primary structures, when seen at 
the surface, lead the casual observer to conclude that basalt flows are quite pervious, especially in the vertical plane. However, at depth, under the load of overlying rock, fractures are for the most part closed and may transmit little or no groundwater. Groundwater movement takes place mostly in the permeable zones in the tops of some flows. These permeable zones are usually about one to three meters thick. Where two permeable interflow zones are separated by a highly-jointed basalt with open joints, the thickness of a single water-bearing zone may be 10 meters or more. The massive centers of some basalt flows are relatively impermeable, and in some places zones of rock consisting of several successive flows are tight and non-waterbearing. These impermeable zones can cause perched water bodies to occur above the regional water table and below the regional water table. They may act as effective confining zones between water-bearing zones of different head.

Evidence to date suggests that, in general, the most permeable watertransmitting zones are sedimentary interbeds or permeable interflow zones involving the permeable top and/or rubble bottom of a flow. Some of the sedimentary interbeds are the best water-transmitting units known to exist in the basalt sequence. Groundwater movement in the Columbia Plateau region is, in general, from upwarped anticlinal areas to downwarped synclinal areas.

Another structural control of regional and local significance is the fault-barrier boundary condition. The faults range from large shear fractures along which the rocks on opposite sides were displaced several thousand feet to small ones on which little displacement has occurred. The watertransmitting characteristics of the fault zones differ markedly from those of unbroken basalt. Fault fracturing may provide a zone of low permeability through which small quantities of water may move vertically, up or down, depending on local head conditions. Permeable interflow zones and sedimentary interbeds, where present, transmit water laterally in a horizontal to subhorizontal direction. In a number of instances, horizontal movement of water has been virtually eliminated by the fault zones. Thus, a fault zone may act as a barrier to otherwise normal lateral movement of groundwater from points of higher to lower head on the Columbia River basalt sequence. Barriers 
to lateral movement of groundwater can also occur along the axes of tight folds, because of the disruption of permeable zones by the interflow grinding that accompanies bedding $\mathrm{plane}$ movement of one flow over another.

Intrusive dikes can also form barriers to lateral groundwater movement, and their presence is most effective when they occur transverse to the direction of lateral groundwater movement. Dikes are known to occur, but they are not as numerous as the structural barriers discussed above.

SUBSURFACE HYDROLOGIC CONDITIONS IN THE PASCO BASIN

The detailed hydrogeology of the Columbia Plateau is not well known. General hydrologic information below a depth of 500 meters in the basalt sequence is lacking throughout the Plateau except for the U.S. Department of Energy's (DOE) Hanford Site in the Pasco Basin. Information gained from hydrologic testing on and adjacent to the Hanford Site is discussed briefly below. The purpose of the discussion is: (1) to define a conceptual layered earth model (LEM) for the types of strata present in the Pasco Basin to a depth of about 1000 meters, and (2) to set some limits and ranges on the permeabilities and head differences that may be applicable for a generic transport modeling scheme of the LEM.

A number of stratigraphic units are present in the Pasco Basin. At a conceptual level, the stratigraphic sequence from the surface downward can be separated into four hydrostratigraphic systems. These are 1) the unsaturated zone, 2) the unconfined aquifer, 3) the uppermost confined aquifers, and 4) the lower Yakima basalt hydrologic sequence.

Unsaturated Zone (UZ)

The unsaturated zone (UZ) is the zone between the land surface and the water table. Perched water bodies may exist within the unsaturated zone. Its thickness at the Hanford Site ranges from less than one meter to more than 100 meters. The unsaturated zone consists of silt and sand deposits of eolian origin and sand and gravel deposits of glaciofluviatile origin. The moisture content of the unsaturated zone of the Hanford Site is very low. 
Unconfined Aquifer System (UAS)

The unconfined aquifer system (UAS) consists of sand and gravel deposits (Pasco Gravels) of glaciofluviatile origin. These deposits rest unconformably on an interbedded sequence of fluvial silts, sands, and some gravels (upper Ringold Formation) which are locally capped by caliche. These deposits are underlain by variably cemented sand and gravel units (middle Ringold Formation). The top of the aquifer at any given time is the water table. The base of the aquifer is either the top of the basalt bedrock in some areas or the silt and clay zones of the lower Ringold Formation in other areas. In places, glaciofluviatile gravel may lie directly on basalt. In such cases, the top of the unconfined aquifer system may be within the glacio-fluviatile gravel. The hydraulic characteristics of the unconfined aquifer system are quite variable. This variability is a result of the heterogenous nature of the aquifer materials in three-dimensional space.

Natural recharge of this aquifer occurs at the foot of the Rattlesnake Hills and the Yakima Ridge and by vertical leakage from the underlying uppermost confined aquifer system. Artificial recharge occurs from waste disposal ponds on the Hanford Site. The Yakima River recharges the unconfined aquifer along its reach from Horn Rapids to Richland. Natural discharge from the aquifer occurs along the Columbia River.

Uppermost Confined Aquifer System (UCAS)

The uppermost confined aquifer (UCAS) consists of: (1) the sands and gravels of the lower Ringold Formation, (2) the sedimentary interbeds of the upper and middle Yakima basalt sequence, and (3) permeable interflow zones in the top few meters of some flow units. Seven sedimentary interbeds are known to exist in the upper and middle Yakima basalt sequence in the Pasco Basin.

The UCAS is known to be hydraulically interconnected at places in the Pasco Basin with the overlying unconfined aquifer. This interconnection occurs where the basalt units have been extensively deformed by folding and differential erosion, such as along major anticlinal axes. Near such folded areas, the basalt flows dip steeply away from the axial plane of the anticline. The ancestral Columbia River deeply eroded away portions of the unconfined aquifer and steeply dipping segments of the uppermost confined aquifer 
units prior to the deposition of younger strata. Therefore, the hydrologic data collected to date suggest that the unconfined aquifer and the uppermost confined aquifer appear to be in hydraulic equilibrium. Recharge to the UCAS appears to occur at the ridges and plateaus fringing the Pasco Basin. The eastern third of the Hanford Site appears to be a discharge area for this aquifer system.

Lower Yakima Basalt Hydrologic System (LYBHS)

The hydrology of the lower Yakima basalt sequence is of utmost importance in assessing the hydrologic suitability of a localized, permanent, waste isolation repository in geologic media of the Pasco Basin. The Vantage Sandstone Formation is the lowermost sedimentary interbed of areal extent known to exist in the Pasco Basin. It separates the lower Yakima basalt sequence from the overlying middle Yakima basalt sequence. Approximately 300 meters below the Vantage Sandstone horizon is a basalt interval ("Umtanum") of special interest. Cores and geophysical logs on this interval suggest that it is a very tight, dense, glassy basalt flow that is about 60 meters thick.

Direct measurements of head, first obtained in 1969, show that the intervals tested in the lower Yakima basalt sequence from a depth of about 915 to 1310 meters tend to have either the same head as intervals tested above the "Umtanum" flow unit (depth of 915 meters) or slightly lower heads.

In 1972, five isolated piezometers were installed in one well on the Hanford Site. Results suggest that a potential hydraulic interconnection of the basalt and interbeds probably exists above a depth of 915 meters (upper confined flow regime). The flow regimes below 970 meters appear to be connected down to a depth of at least 1480 meters (lower confined flow regime). The "Umtanum" flow unit separates these two hydraulic flow regimes. It would appear that the difference in head between the upper and lower flow regimes is presently about two meters, with the potential flow direction being apparently from the lower confined to the upper confined flow regime. 
Very little is known about the direction and movement of groundwater through the lower Yakima basalt sequence and its contained interbeds. However, groundwater movement in the deep rock sequence should be influenced by primary and secondary basalt flow solidification structures and tectonic structures, chiefly fractures (joints and faults).

\section{LAYERED EARTH MODEL}

The conceptual layered earth model (LEM) represents the major types of porous media (LEM units) that may be encountered at a number of places on the Columbia Plateau, and specifically in the Pasco Basin. The purpose of the LEM is to provide a basis for gauging the effect that disruptive event phenomena of a geologic nature might have on a radioactive waste repository in geologic media of the Columbia Plateau physiographic province. Anyone using the conceptual LEM should understand that it is not representative of the actual three-dimensional hydrostratigraphic sequence and hydrologic conditions existing at any specific site within the Columbia Plateau physiographic province. However, the LEM may be useful for gaining a better understanding of how the hydrologic regime, and specifically transport rates, may change as a result of disruptive events that may interact with a waste repository in geologic media.

A conceptual LEM is presented, consisting of 18 layers. The LEM does not represent the minimum or maximum number of layers that might be invalved in a Columbia Plateau repository site. However, it shows the degree of complexity that is known to exist in the vertical plane.

The estimated range in the hydraulic conductivity of each LEM unit is based on cursory field data acquired at the Hanford Site. The range in the vertical hydraulic conductivity of the various LEM units is not well known. However, it appears reasonable to assume that the vertical hydraulic conductivity of a specific LEM unit is at least one order of magnitude and possibly two orders of magnitude less than the horizontal hydraulic conductivity. This conclusion is probably not applicable to some of the thinner basalt flows that have a well-developed colonnade section; i.e., the vertical permeability may be considerably higher than the horizontal permeability where the depth of burial is relatively shallow. 
Some of the basalt flows are highly jointed. Field and rock core evidence, however, suggests that some of these flows may be impervious to water. Inspection of basalt joints and fractures shows that secondary minerals, predominantly clays such as beidellite and nontronite, fill the joints and other fractures, effectively sealing them.

Hydraulic head relationships between the unconfined aquifer system (UAS), uppermost confined aquifer system (UCAS), and the lower Yakima basalt hydrologic system (LYBHS) are known in a general way. The potentiometric surface of the UCAS ranges from less than one meter to about four meters higher than the potentiometric surface of the overlying UAS. For initial modeling purposes, it is recommended that head differences ranging from 1 to 10 meters be considered for these two aquifer sequences. The flow potential should be from the UCAS to UAS. The potentiometric surface of the LYBHS is about two meters higher than the overlying UCAS; therefore, the apparent potential for flow is from the LYBHS to the UCAS. Because the head relationships of these two aquifer systems may be reversed at specific sites, it is recommended, for initial modeling purposes, that head fluctuation ranging from 1 to 10 meters be considered, with comparative runs for flow from the LYBHS to the UCAS and from the UCAS to the LYBHS.

The hydraulic gradient in the UAS ranges from about 0.5 meter to 5 meters per $\mathrm{km}$ throughout the Pasco Basin. The gradient is highest near recharge sources, such as the waste disposal ponds of the 200 West and East Areas of the Hanford Site. The hydraulic gradient in the UCAS is less well known than for the UAS. The range in the hydraulic gradient is probably less, in general, than stated above for the UAS; however, it may be greater near the edge of the Pasco Basin (recharge area) and the Columbia River (discharge area).

Little is known about the hydraulic gradient of the LYBHS. It is probably very low in the central part of the Pasco Basin. For initial modeling simulation runs, a hydraulic gradient range of 0.1 to 1 meter per $\mathrm{km}$ is probably the correct order of magnitude. 


\title{
CHAPTER VIII
}

\section{GENERAL SUBSURFACE GEOLOGY OF SOUTHEASTERN NEW MEXICO}

WITH SPECIAL REFERENCE TO ITS STRUCTURAL STABILITY

\author{
J. Hills
}

University of Texas, El Paso

PURPOSE OF THE STUDY

This study was undertaken to assess the subsurface geological factors that might affect the suitability of southeastern New Mexico as a possible site for a nuclear waste repository.

\section{ASSUMPTIONS AND METHODS}

The time frame within which the stability of the region has been considered is one million years. It has been assumed that, within this time period, continental drift or movement of the North American plate will not greatly affect the stability of the rocks of the area.

Five cross sections were made across Eddy and Lea Counties, New Mexico; four in an east-west direction and one in a north-south direction. The tectonic stability of the area has been judged by the available well records and the results of a University of Texas at El Paso seismic study of Ward, Winkler and Loving Counties, Texas, as well as adjacent parts of New Mexico. News reports of minor earthquake activity were also taken into account.

\section{CONCLUSIONS}

1. Southeastern New Mexico east of the Pecos River is a tectonically stable area with no major fault movements for the past $250 \mathrm{million}$ years. No major tectonic adjustments are expected in the next million years.

2. Minor tectonic adjustments during Triassic time (200-180 million years ago) and early Tertiary time (70 million years ago) have resulted in 
deepening and eastward tilting of the Delaware basin. These tectonic adjustments have resulted in the opening of joints and consequent solution of the upper part of the Salado salt. Compaction of Pennsylvanian and Lower Permian sediments has also contributed to the basin subsidence. This effect has been most severe on the west edge of the basin near the Pecos River and in the southeast edge of the basin adjoining Winkler County, Texas.

3. Recent minor seismic activity is probably the result of petroleum secondary recovery operations. This seismic activity may result in the release of strain and may contribute to the long term tectonic stability of the area.

GENERAL GEOLOGY

Southeastern New Mexico is on the southwestern edge of the North American craton. It contains the northern end of the Delaware basin of late Paleozoic age and the adjacent wide northern and northwestern shelves in northern Eddy and Lea Counties. On the extreme east in Lea County is the edge of the Central Basin Platform. The geological conditions and history of the region are well known from the information gathered from thousands of petroleum tests drilled during the last fifty years. Many of these holes were drilled to the Precambrian basement, so that the entire sedimentary cover has been explored.

The surface of the area is generally very flat with new hills of recent sands and Triassic shales standing above the general fill of Pleistocene sands. The surface is about 3350 feet above sea level.

Relation to Large Scale Structural and Sedimentational Features

The area of interest is located in the northern part of the Delaware basin. This basin is bounded by the Capitan reef, a large, linear, sedimentary structure of Late Permian age. The depth to the Precambrian basement in the vicinity is about 18,000 feet, and the depth to the base of Permian age rocks is about 13,000 feet. The site location is some twenty-five miles west of the west edge of the Central Basin Platform. 


\section{Structure}

The structure of the bedrock in southeastern New Mexico is concealed by Recent sands and by residual gypsum and red clay derived from the weathering of the Upper Permian evaporites and red shales. Occasional remnants of Triassic red beds and Pleistocene sandstones, conglomerates, and caliche form low ridges on the surface. Thus, bedrock structures must be inferred from drill hole records or seismic interpretation.

The folding in these rocks is gentle, with two to three degrees dip on the flanks of anticlines. The pre-Permian rocks of the east-tilted Delaware basin have dips of about 100 feet to the mile (one degree) to the east and east-northeast. However, along the edge of this basin, the development of the Capitan reef has resulted in an original dip in the Upper Permian beds of some three degrees southward toward the Delaware basin from the top of the reef in the north. Compaction of the fine grained clastic rocks of the Delaware basin during Late Permian and Triassic time may have contributed to the development of this basinward dip. On the east side of the basin, slight tectonic movement along the west side of the fault zone probably has accentuated the dip into the basin.

The two well-defined folds in the area are in Antelope Ridge and Bell Lake fields. In Antelope Ridge the Silurian rocks, and presumably the underlying strata, are folded into an anticline with a dip of about two and one-half degrees on the flanks and a north-northeast axial trend. In Bell Lake, the Devonian beds are folded into an anticline with about two degrees dip on the flanks and a north-south axis.

\section{Faulting}

Knowledge of the general fault framework of the Permian basin is based on occasional penetration of the faults by well bores and interpretations of the subsurface conditions necessary to account for the position of the formations as shown by well logs. The displacements along those faults are confined to the pre-Permian rocks, with only occasionally an apparent displacement of the Wolfcamp (Lower Permian) rocks. The faults identified from the cross sections 
are reverse. In we 11 bores it is easier to detect the repetition of beds caused by reverse faulting than the missing beds due to normal faulting, because missing beds can be often accounted for by unconformities. Therefore, some normal faults may go undetected. The reverse faults are straight or gently curving and are of steep dip, so these faults are penetrated by relatively few wells. Some of these faults have been well defined in fields a few miles to the south in Winkler County, Texas, as well as in southeastern New Mexico.

The straight traces and steep dips of these faults suggest that they were originally formed in Precambrian time as lateral faults. In Mississippian and Pennsylvanian time, compressional stresses connected with the Marathon-Ouachita orogeny caused extensive vertical movement and possibly some lateral movement along the old fault zones. The differentiation of the Delaware basin from the Tobosa basin occurred during this time. At the rate of one millimeter per year, the total 10,000 feet of displacement could take place in three million years, so it is probable that the displacement occurred over several geologically short episodes distributed over the sixty million year interval from Late Mississippian to Early Permian. Most of the movement may have occurred during Middle Pennsylvanian.

The east line of the West Platform fault zone extends northward from Lea County at the Texas boundary to the Eumont oil field. This line is drawn at the Lower Permian fault outcrop. The eastern part of this fault zone consists of several fault blocks downthrown to the west along reverse faults steeply dipping to the east. Total apparent displacement along this subzone is about 10,000 feet on the upper surface of the Precambrian basement. No fault displacement has been detected in the Upper Permian or younger rocks along this faulted subzone. Probably a reflection of this zone is seen in the unusually straight line of the western edge of the dolomite-reservoired Upper Permian oil fields. This same line continues southward through Winkler and Ward Counties and into Pecos County, Texas. It is probably due to basinward progradation of reefs and banks from a submarine fault scarp in the Permian sea. The present position of the field edge west of the fault zone boundary is probably due partly to this progradation of the Permian 
carbonates and partly to slight subsidence of the basin along the faults of the western part of the subzone. This movement may have occurred in Late Permian or Early Triassic time.

The western edge faults differ from the eastern in that they seem to dip to the west, but they remain reverse in sense. An apparent fault graben separates the two sides of the fault zone. The Late Permian Capitan reef follows the western side of the zone fairly closely. The exact reef location may depend on the relative times of movement of the two sides of the zone. The reef probably started its growth on the prominent submarine fault scarp furthest basinward.

\section{TERTIARY INTRUSIVES}

Cuttings from a basalt dike in the area were dated by the potassiumargon method as $30 \pm 1.5$ million years old. This northeastern trending dike was mapped as far east as the Kerr-Magee potash mine, and it was concluded that this dike parallels the joints in the Capitan reef. The thickness of the dike in the Kerr-Magee mine is from 6 to 200 feet. 0ther dikes and sills have been reported from various wells in the Delaware basin. In areas to the north of the basin in New Mexico, similar dikes form prominent linear outcrops before plunging into the subsurface. By magnetic methods, these dikes can be traced eastward in the subsurface as far as the Texas boundary. However, there have been no intrusions reported which appear to be younger than Miocene.

\section{HISTORY OF THE FAULTED ZONE SINCE LATE PERMIAN}

Because the Capitan and its connected back reef beds must have been deposited originally at approximately sea level, the present lower position of the Capitan reef on the east side of the Delaware basin indicates that there has been negative movement of this part of the basin or, conversely, relatively positive movement of the Central Basin Platform since Permian time. However, this movement must have been very slow and probably was largely accommodated by either bending or very slight displacement of the 
Permian beds. Much of this movement may have been due to compaction of the sedimentary fill of the basin. No detectable displacement of Permian and younger beds can be seen in well records.

Furthermore, there is, at present, a difference in elevation of over 9000 feet in the top of the Capitan from its outcrop at 8700 feet in Culberson Country, Texas, to its top in the subsurface just north of Winkler County, Texas, ninety miles to the east at 500 feet below sea level. The Capitan reef enters the subsurface at the Pecos River in Carlsbad. It extends eastward through oil fields to the northeast corner of the Delaware basin, where it curves south-southeast. Then the reef elevations remain approximately the same for many miles southward into Texas. This reef, as pointed out above, is just a few miles west of the west edge of the Central Basin Platform. The West Platform fault controls that edge of the Central Basin Platform.

Therefore, it appears that the faulted zone underlying the west edge of the Central Basin Platform was a hinge line along which the tilting of the Delaware basin occurred. The evaporites overlying the Capitan and also the Rustler Formation at the top of the Permian section are tilted, so it seems fairly obvious that most of this tilting must have happened after the close of Permian deposition in the area. The Upper Triassic red beds thin rapidly to the west, and therefore it seems probable that much of this tilting occurred in Early Triassic time. However, the continental Upper Triassic Dockum beds reach a thickness of 1500 feet on the Central Basin Platform, so this much of the tilting must have taken place in Late Triassic time.

Recrystallization of the Salado salt in the easternmost potash mines northeast of the site seems to have happened on a somewhat larger scale than in the mines to the west. This more extensive recrystallization may have been a result of the slight opening of joint cracks by faulting, allowing brine to circulate in the halite beds and potash beds. This movement may have been connected with the uplift of the western side of the Delaware basin during the Laramide orogeny in early Tertiary time. 
Evidence of possible more recent very slight movement along the fault zone at the west edge of the Central Basin Platform is the presence of thick early Pleistocene sands in Ward and western Winkler Counties in Texas, extending into New Mexico. These sandstones apparently fill old channels that have been formed by the solution of underlying Upper Permian evaporites which immediately overlie the Capitan reef trend. It is possible that very slight movement in late Tertiary time opened joint planes and made solution of the Upper Permian salts in this area possible.

Whether or not slight adjustments of this nature are presently continuing is a question that must be answered by detailed seismic studies. Recent news reports of earthquakes of low to moderate intensity in the region, as we 11 as seismic studies by a University of Texas at El Paso group, indicate that very slight tectonic activity is present in the West Platform fault zone. Injection of fluids at high pressure into Upper Permian petroleum reservoirs in connection with secondary recovery operations may be the cause of this phenomenon. Foci of these earthquakes are at approximately the same depth as the displacements of the lower Paleozoic rocks in the fault zone at the western edge of the Central Basin Platform.

If these quakes are indeed artifacts promoted by injection of fluids into petroleum reservoirs, they may be expected to cease with the end of major petroleum production in the region, perhaps in 100 years. These small quakes, however, probably relieve the strain caused by westward and southwestward stresses between the Central Basin Platform block and the lower standing Delaware basin crustal segment. Thus, the quakes may promote longterm tectonic stability of the area. However the case may be, the evidence indicates that southeastern New Mexico is now and has been a region of exceptional tectonic stability during the last million years.

\section{POSSIBLE FAULT MOVEMENTS CAUSED BY SALT SOLUTION IN THE CENTRAL} DELAWARE BASIN

The presence of large quantities of gypsiferous red clays and sands on the surface and in wells located as far as eight miles east of the Pecos 
River indicates extensive solution of the Rustler and Salado salts. Physiographic evidence, such as bluffs of gypsum and Rustler dolomite on the east side of the river and westward dipping slopes of older limestones on the west side of the river, shows that the Pecos River has moved down dip to the east in Pliocene and Pleistocene times. This movement has been promoted by solution of the Salado and Rustler salts, hydration of the anhydrite to gypsum, and solution of this sulphate by the underflow of the river. Later stream flow transported the residual clays and sands, as well as the solutions, downstream.

This process seems to be continuing today and collapse of the overlying rocks is obviously occurring. Collapse of these rocks may cause faulting in the Upper Permian rocks. Although not of tectonic origin, this faulting at some time in the future may be capable of breaching a repository excavated in the Salado Formation. The Salado is especially vulnerable to such dissolution, because it has numerous seams and beds of clays and sands within it which could act as conduits for the dissolving brines. It is also overlain by the basal sandstones of the Rustler, which have acted in the past as dissolving aquifers and probably will continue to act in this way. Solution is aided by waters from aquifers formed in the overlying Rustler oolitic dolomites.

Faults caused by removal of support by dissolution are probably of small displacement, perhaps a few feet. These faults would not extend below the base of the dissolved zone, probably the Salado. It is unlikely that they would be evident on the surface, because the movement would be absorbed by the shallow Triassic shales, Holocene sands and residual material left by dissolution of the salt.

Evidence of the probable lower limit of the solution is seen in the wells to the west. In that area, solution has removed most of the Rustler formation, the Salado salt, and the upper part of the Castile Formation. The lower part of the Castile, however, consists of 600 feet of anhydrite varved with brown calcite, overlying several massive salt beds. These beds are confined to the Delaware basin. The beds underlie the Pecos River and show little, if any, signs of salt dissolution. This lack of dissolution is in 
contrast to the almost complete solution of the younger Salado beds. Apparently, the relatively insoluble Castile banded anhydrite can be counted upon to protect the lower salts from dissolution at depth. Thus, any solutioncaused faults probably will not extend below the top of the Castile banded anhydrite. A 300 foot thick salt bed in the lower part of the Castile, occurring at 4000 feet depth in the area, would seem to be secure from such solution within the next million years.

Such dissolution-caused faults cannot be mapped from well records or surface examination, but they might be located by detailed high resolution seismic examination of southern Eddy County east of the Pecos River. It is possible that some very low intensity seismic activity caused by dissolutionrelated faulting might be detected by closely-spaced, highly sensitive seismometers. 


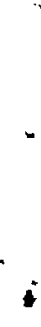

-
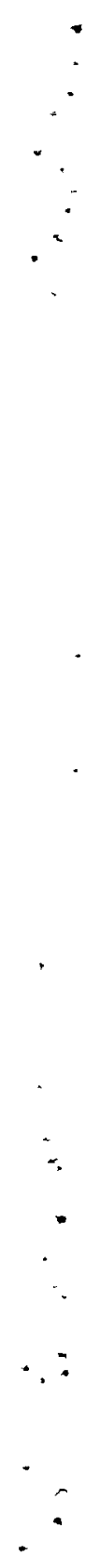
CHAPTER IX

\section{SEA LEVEL REPORT}

M. L. Schwartz

Western Washington University

\section{INTRODUCTION}

Sea level changes are an important factor in the study of a site under consideration as a radioactive waste repository. If sea level rises relative to the repository there are potential problems in erosion, sedimentation, submergence, and saturation. If sea level falls relative to the repository there are potential problems in erosion, leaching, lowering of the water table, and lowering of base level.

Furthermore, sea level changes relate directly to plate tectonic, glacial, and climatic events, which, in turn, are important considerations in siting of a waste repository.

For all of these reasons, the investigation of past and possible future sea level changes becomes a vital component of any systematic approach to the radioactive waste isolation problem.

\section{CENOZOIC SEA LEVEL}

The following discussion deals with sea level changes during the Cenozoic Era. The discussion is divided into several sections, dealing with the following intervals of time: the last 20 million years of the Tertiary Period; the 2 million years of the Quaternary Period (the Pleistocene Epoch); and the last $17,000,100$, and 10 years.

Tertiary Sea Leve 1

During Miocene-Pliocene times sea level was descending, either at a steady rate or oscillating downward (Tanner, 1968), through a period of 
20 million years. Such a prolonged and uniform change could be explained either by an expanding earth hypothesis or by global tectonics theory. The general concensus appears to favor the latter. According to proponents of the global tectonic approach (Wyllie, 1976; Valentine and Moores, 1972), active plate break-up is followed by a time of transgression caused by general midocean ridge uplift and spreading, as well as by thermal expansion of ridge areas. After the initial transgression, there is an interval of regression as the ridge area both contracts and subsides. Thus, the mid-Mesozoic break-up of Pangaea was followed by high sea levels during the Cretaceous Period and by continually lowering sea levels during the period of quiescence that has ensued since then. The changing of sea level by basin enlargement or reduction is referred to as tectono-eustatic.

Pleistocene Sea Level

Pleistocene Epoch sea levels fell and rose with the advance or retreat of the ice caps (Bird, 1969). Water was subtracted from or added to the oceans as ice was alternately accumulating on or melting off of the land. The chang ing of sea level caused by growth or ablation of glaciers is referred to as glacio-eustatic.

Of the many mechanisms which have been proposed to initiate glacial advance and retreat, one appears to have gained a slight preponderance of acceptance over the others. This is the Milankovitch Theory, which is based on the additive or subtractive influence of three climate-producing variations of the earth's position and path in space (Table IX.1).

TABLE IX.1. Variable Components of the Milankovitch Theory

$\begin{array}{ll}\text { Axial Precession } & 21,000 \text { years cycle } \\ \text { Axial Tilt } & 40,000 \text { years cycle } \\ \text { Orbit Ellipticity } & 92,000 \text { years cycle }\end{array}$

The advent of glacials and interglacials is correlated with the result of these cycles being in or out of phase with one another. 
The interglacial high sea levels and glacial low sea levels appear to have been imposed upon an overall continual fall in sea level. Thus, there was a shorter-term, glacio-eustatic oscillation of sea level superimposed upon the later part of a longer-term, tectono-eustatic lowering of sea level.

Flandrian Transgression

The rise of sea level that followed the ebb of the last glacial age, the Wisconsin, is obvious. Yet experts do not agree upon the pattern of that rise. The many variations that are proposed fall into three categories: stillstand, higher-than-present, and asymptotic. According to the stillstand proponents, who are considerably in the minority, sea level reached its present level 3,000 to 5,000 years ago and has remained essentially stable since then. The higher-than-present curve, as recently refined by Fairbridge (1976), follows a fluctuating rise which exceeded present sea level some 4,000 years b.p. and has been oscillating above and below, in diminishing increments, since that time. Asymptotic refers to a rapid initial rise, gradually tapering off to the present level. The latter two curves are, jointly, the most widely accepted. The asymptotic curve finds favor in North America, but the Fairbridge curve predominates around the rest of the world.

Mid-1800 To Mid-1900, and Present

Tide data, mainly from the Netherlands, indicate that from the mid-1800's to the mid-1900's there has been a world-wide rise in sea level of about $1.2 \mathrm{~mm}$ yr. Somewhat shorter-term tide records from the east coast of the United States indicate that there was a slight dip in sea level in the mid1960's (Hicks, 1973). This temporary reversal of the longer trend, however, was followed by a continuation of the rise into the 1970's.

\section{SEA LEVEL FLUCTUATIONS: RATES AND PARAMETERS}

Rates and parameters of sea level fluctuations were discussed at a sea level prediction symposium that was convened on 0ctober 31, 1977, at Western Washington University. Coastal specialist participants included:

Dr. E. C. F. Bird, University of Melbourne; Dr. F. Danes, University of Puget Sound; Dr. R. W. Fairbridge, Columbia University; Dr. M. L. Schwartz, Western 
Washington University; and Dr. H. J. Walker, Lousiana State University. Some of the information on sea level changes that was provided by the symposium participants is included in the following discussion.

Some of the factors affecting sea level changes are: the galactic cycle, paleogeography, the variables in the Milankovitch Theory, albedo, solar cycles, sun tides, steric effects, glacio- and tectono-eustacy, and tectonic movements. For the one million year time period being considered for the Waste Isolation Safety Assessment Program, glacio-eustacy and tectono-eustacy are of primary importance. Table IX.2 contains information about parameters of sea level change.

\section{TABLE IX.2. Expected Parameters of Sea Leve1 Change}

\begin{tabular}{|c|c|c|c|c|c|}
\hline Type & Time (yrs) & Pos. & Neg. & $\begin{array}{l}\text { its }(\mathrm{m}) \\
\text { mplitud } \\
\text { or } \\
\text { Range }\end{array}$ & Locale \\
\hline Tectono-eustatic & $10^{6}$ & 250 & 250 & 500 & global \\
\hline Glacio-eustatic & $10^{5}$ & 100 & 100 & 200 & global \\
\hline Glacial surges & $10^{2-3}$ & 20 & & & global \\
\hline Tsunami & Less than 1 & 200 & 20 & & local \\
\hline Storm surge (seiche) & Less than 1 & 10 & $1-2$ & & local \\
\hline Concurrent glacio- and & & & & & \\
\hline tectono-eustatic & & 350 & 350 & 700 & global \\
\hline
\end{tabular}

At present, mean sea level $r$ ise is recorded at $3-4 \mathrm{~mm} / \mathrm{yr}$. Of that 3-4 mm, 1-2 mm/yr is attributed to eustacy and $2 \mathrm{~mm} / \mathrm{yr}$ is attributed to subsidence. However, maximum sea level rise can be as much as $4 \mathrm{~cm} / \mathrm{yr}$. During the Quaternary Period, maximum changes on the order of $2 \mathrm{~cm} / \mathrm{yr}$ have been associated with both eustatic changes and tectonic movements. During this period of time these extreme fluctuations of both eustatic and tectonic movements have occurred in various directions. Hence, eustatic rise combined with tectonic subsidence could produce a maximum increase in sea level of $4 \mathrm{~cm} / \mathrm{yr}$. Sea level lowering could also reach $4 \mathrm{~cm} / \mathrm{yr}$, provided that a eustatic fall were accompanied by a tectonic rise. 
FUTURE SEA LEVEL CHANGES

Of all of the factors affecting a glacio-eustatic change in sea level over the next million years, the variables dealt with in the Milankovitch Theory are the most important. Therefore, this theory has been used as a basis for projecting climatic-induced changes in the level of the sea. According to the Milankovitch Theory, another glacial sea level low should be expected. Vernekar (1972) has calculated variations in incoming solar radiation for 119,000 years into the future. His data show secondary lows at 15,000 and 118,000 years and primary lows at 53,000 and 98,000 years. Berger (1976a, 1976b) also projects the variable considered by Milankovitch, in this case to 1 million years into the future. The Berger graphics are somewhat more difficult to interpret, in terms of glacial advance and retreat, than those of Vernekar. Yet, for the next 1 million years into the future, there is reasonable justification for expecting glacio-eustatic sea level oscillations akin to those of the last 2 million years of the past.

Predictions of future tectono-eustatic sea level changes are somewhat tenuous and difficult to make. Data from the later part of the Tertiary Period show a decline of $80 \mathrm{~m}$ in 20 million years. Sea level fell at a more rapid rate during the Pleistocene Epoch; the overall lowering during the Pleistocene, which lasted for less than 2 million years, was on the order of $100 \mathrm{~m}$. To predict whether this trend will continue, it would be necessary to know more about present and future tectonism. Predictions about sea level changes necessarily involve predictions about tectonic activity. A future, perhaps imminent, phase of ridge activity could cause a rise of sea level. The Red Sea and Gulf of California are now centers of spreading, and eastern Africa may or may not be. On the other hand, the major ocean floors will move laterally about 20 to $50 \mathrm{~km}$ in the next million years, and that would not appear to put the continents in a transgression-causing position. At this point, perhaps, we must turn to the geophysicists for some answers.

An important factor in predicting sea level changes at a particular continental coastal site is the stability of that locale. Elevation changes from local tectonic uplift or subsidence could far outweigh world-wide 
tectono- or glacio-eustatic sea level changes. At a particular segment of the shore, sea level changes may be as much a matter of vertical displacement of the land as it is a rise or fall of the water surface level.

\section{COASTAL EROSION AND SEDIMENTATION}

\section{Processes}

An understanding of the processes of coastal erosion and sedimentation is important in any discussion about sea level changes. If sea level rises $50 \mathrm{~m}$ against a coast, the land will not be eroded $50 \mathrm{~m}$ down as a result. At any new stand of sea level, normal surf- or surge-base erosion will extend to $10 \mathrm{~m}$ below mean lower low water (MLLW). In regions of exceptionally high wave energy, such as the Capetown area of South Africa, erosion may extend to $20 \mathrm{~m}$ below MLLW. Therefore, a transgression does not in itself imply deep erosion. In the case of salt domes, they would suffer less from deep submergence than from engulfment (i.e., partial submergence). The latter, leaving them standing as offshore islands, would expose them to wave erosion along their seaward side. This situation could, in fact, result in erosion of the domes down to the level of the surrounding general topography.

As for sedimentation, very little pelagic sediment would come out of the shallow coastal water itself. Most sediment deposition would result from: a) sand being transported in with the transgressing sea, b) erosion of coastal topographic highs, c) shore drift along the coast, and d) runoff from the land. Of these, the latter, as deltas, would probably account for the largest magnitude of sedimentation at a given site. This would, of course, depend on the local relief and climate; but it is valid enough as a first order approximation.

$\underline{\text { Rates }}$

Sediment accumulation rates and erosion rates were among the topics of discussion at the sea level prediction symposium convened at Western Washington University on October 31, 1977. Erosion rates agreed upon by the symposium participants are listed in Table IX.3. 
TABLE IX.3. Typical and Maximum Erosion Rates Associated with Coastal Provinces

\begin{tabular}{lll} 
& \multicolumn{1}{c}{ Typical } & $\frac{\text { Maximum }}{50 \mathrm{~m} / \mathrm{yr}}$. \\
Soft sediments (sandy to deltaic) & $1 \mathrm{~m} / \mathrm{yr}$. & $50 \mathrm{~m} / \mathrm{yr}$. \\
Permafrost (high latitudes) & $1 \mathrm{~m} / \mathrm{yr}$. & \\
New volcanic material (a) & $1 \mathrm{~m} /$ day & \\
Mudlumps (a) & $1 \mathrm{~m} /$ day & \\
Hard rock $(\mathrm{b})$ & less than $1 \mathrm{~cm} / 100 \mathrm{yr}$.
\end{tabular}

(a) Very loose material introduced into a high energy environment. (b) Non-weathering, only wave erosion.

Sediment accumulation rates can be as high as $20 \mathrm{~m} / 100 \mathrm{yr}$ during uplift of coastal areas. The Mississippi Delta surface rises, by accretion, up to $1 \mathrm{~m} / 100 y r$ during a rise in sea level.

CONCLUSIONS

A study of Cenozoic Era sea levels shows a continual lowering of sea level through the Tertiary Perod. Short term fluctuations were superposed upon this general trend of sea level lowering. This overall drop in sea level accompanied the Pleistocene Epoch glacio-eustatic fluctuations, causing each succeeding glacial low and interglacial high to fall at a lower level.

The considerable change, during relatively short spaces of time, of Pleistocene Epoch sea level is most directly attributable to the glacioeustatic factor. The effect is worldwide with a time span of $10^{5}$ years and an amplitude or range of approximately $200 \mathrm{~m}$.

The continuing and overall lowering of sea level that has occurred worldwide since the end of the Cretaceous Period is attributed to a subsidence in the world ocean floor and mid-ocean ridges accompanying a decrease in platetectonic activity during that time.

The maximum rate for sea level change is $4 \mathrm{~cm} / \mathrm{yr}$. At present, mean sea level is rising at about $3-4 \mathrm{~mm} / \mathrm{yr}$. 
Glacio-eustacy and tectono-eustacy are the parameters that are most important for making predictions about sea level changes in the next 1 my. Glacio-eustatic sea level changes may be projected on the basis of the Milankovitch Theory. Predictions about tectono-eustatic sea level changes, however, involve predictions about future tectonic activity and are therefore somewhat difficult to make.

Coastal erosion and sedimentation are affected by changes in sea level. Erosion rates for soft sediments may be as mush as $50 \mathrm{~m} / \mathrm{yr}$. The maximum sedimentation accumulation rate is $20 \mathrm{~m} / 100 \mathrm{yr}$.

\section{REFERENCES}

Berger, A. L. 1976a. Long-term Variations of the Earth's Orbital Elements, in Abstracts of Forthcoming Articles. Celestial Mechanics. 13:523.

Berger, A. L. 1976b. Obliquity and Precession for the Last 5,000,000 Years. Astronomy and Astrophysics. 51:128-135.

Bird, E. C.F. 1969. Coasts. Cambridge, M.I.T. Press, 246 pp.

Fairbridge, R. W. 1976. Shellfish-eating Preceramic Indians in Coastal

Brazi1. Science. 191:353-359.

Hicks, S. D. 1973. Trends and Variability of Yearly Mean Sea Level

1893-1971. Rockville, U.S. Department of Commerce, NOAA Technical Memorandum No. $12,13 \mathrm{pp}$.

Tanner, W. F. 1968. Tertiary Sea Level Symposium-Introduction. Paleogeography, Paleoclimatology, Paleoecology. 5:7-14.

Valentine, J. W., and E. M. Moores. Global Tectonics and the Fossil Record. Journal of Geology. 80:167-184. (Also reprinted in: Cowen, R., and J. H. Lipps. 1975. Controversies in the Earth Sciences. St. Paul, West Publishing Co., pp. 173-198.)

Vernekar, A. D. 1972. Long-Period Global Variations of Incoming Solar Radiation. Meteorological Monographs. 12(34):12 with tables.

Wyllie, P. J. 1976. The Way the Earth Works. New York, Wiley \& Sons, 296 pp. 
CHAPTER $X$

HYDROLOGIC EFFECTS OF NATURAL DISRUPTIVE EVENTS ON

NUCLEAR REPOSITORIES

S. N. Davis

University of Arizona

The assessment of hazards to deeply buried nuclear repositories must include consideration of several possible mechanisms of containment failure. One of the most difficult mechanisms to assess is the upward transport of radionuclides into the biosphere by slowly moving groundwater. This mechanism is, moreover, one of the most likely failure modes, particularly if some disruptive event (such as faulting) affects the repository.

The purpose of the present report is to review some of the hydrogeologic aspects of containment failure, particularly in relation to natural disruptive events. Attention will be focused on geologic environments typical of salt domes in the Gulf Coast, bedded salt in Texas, Oklahoma, and New Mexico, and various media found in the Nevada Test Site. Although this report will not concentrate on site-specific details, hydrogeologic properties discussed, insofar as possible, will be based on actual field investigations.

This report describes some possible hydrogeologic effects of disruptive events which may affect repositories for nuclear waste. Although the importance of human activities in possible containment failure is apparent to all students of the problem, the present report concentrates on the effects of natural events. A very large number of combinations of natural events can be imagined; nevertheless, this report covers only those events which are judged to be most probable.

Failure of the containment of deeply buried radioactive waste, if it occurs, would most likely involve some transport of radionuclides by groundwater. The prediction of the future groundwater motion is, therefore, of 
prime importance. Although sorption characteristics of the media are of primary importance in radionuclide transport, the objective of the present review is to discuss the nonchemical aspects of natural disruptive events. Of the nonchemical variables, the permeability of the material is most difficult to estimate accurately for a given transport problem. Even if present field conditions were known perfectly, future geologic processes, such as compaction, weathering, fracturing, and cementation, could easily change current values of permeability by several orders of magnitude. Reasonable values are given in this report for various natural materials, but they represent only the median value in a set of log-normally distributed values from a given formation.

Effective porosity values, which also govern the flow velocities and are inversely proportional to those velocities, vary between about 0.001 and $0.2(0.1 \%$ and $20 \%)$ for most water-bearing materials. Because effective porosity has a normal distribution in samples from a given formation, moderately close estimates of the effective porosity can be obtained with only a limited number of field determinations. Dispersion, which is another critical factor in transport equations, is difficult to estimate, and laboratory determinations of dispersivity are almost meaningless when applied to field situations. Generally, field values are at least one or two orders of magnitude larger than corresponding laboratory determinations would suggest. Good field determinations of dispersivity are unfortunately very scarce.

Numerous disruptive events could cause a containment failure in a nuclear waste repository. Of the natural events which may induce undesired groundwater transport of radionuclides, faulting, dissolution of rocks, miscellaneous fracturing, and rapid changes of the groundwater regime are considered the most probable. Most disruptive events will cause some new groundwater flow patterns to develop in response to increased permeability of the rocks or an increased amount of groundwater. Increases in groundwater may be due to increases in water available for recharge. As a first approximation, natural disruptive events can be assumed to produce permeable zones that allow instantaneous injection of contaminated water into adjacent permeable rocks. This assumption is very conservative and should only be used when details of the natural system are not available for more realistic models. 
Permeability increases produced by faulting have been a cause of concern with respect to the integrity of a waste repository. However, contrary to many published reports, faults do not necessarily increase the permeability of rocks that are affected. Many active faults in California have been documented to be groundwater barriers. Furthermore, recent faults in other regions commonly show evidence of local decreases of permeability. In general, faults that offset nonindurated sediments tend to form hydraulic barriers, and only geologically young normal faults traversing older brittle rock are always zones of high permeability.

Dissolution of anhydrite, gypsum, limestone, dolomite, and salt can form collapse features, which may disrupt nuclear repositories. The dissolution may be relatively slow, with a corresponding slow settling and failure of overlying material. Occasionally, the dissolution produces subsurface cavities that collapse suddenly and sometimes catastrophically. Dissolution with subsequent collapse is probably the most likely form of containment failure for repositories in bedded salt and salt domes.

Non-tectonic fracturing of rock may be associated with large landslides, subsidence of alluvial basins, and impact and explosion events. Proper site location should avoid most areas of non-tectonic fracturing.

Rapid changes of the groundwater regimen are particularly difficult to predict. In general, if one takes the elevation of the local recharge area and assumes that groundwater fills all pore spaces to the surface, and if the exit head is assumed to be stable, then most regional groundwater gradients in humid areas are not even doubled. In arid regions, in contrast, the gradients may be more than tripled. Because transport velocities are almost everywhere proportional to the gradients, the rates of movement of radionuclides will be increased accordingly. The most serious problem which could come from changes in the groundwater regimen appears to be a shortening of the groundwater flow path. If groundwater levels increase in elevation until the water is near the surface, then long regional flow paths of contaminant travel may become short, local paths. Stated in another way, a large increase in the quantity of local groundwater may cause a more direct and rapid movement of contaminants to the surface. 


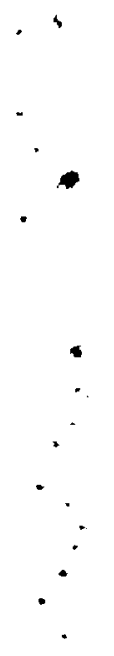


CHAPTER XI

STRUCTURAL GEOLOGY OF THE COLUMBIA PLATEAU AND ENVIRONS AS RELATED TO THE WASTE ISOLATION SAFETY ASSESSMENT PROGRAM

H. A. Coombs

University of Washington

\section{INTRODUCTION}

The purpose of this report is to provide information on the structural geology of the Columbia $\mathrm{Plateau}$ in regard to selecting a site for radioactive waste disposal.

The chief concern in studying the structural history of the Columbia Plateau is to establish criteria for geologic stability that would permit some degree of assurance that the area is relatively inactive tectonically and will remain so for the next several hundred thousand years.

This report describes the folding and faulting that has taken place during the past several million years, thus providing background for the general stress conditions of the area and giving clues to the mechanism of deformation.

\section{THE COLUMBIA PLATEAU AND RELATION TO ADJACENT AREAS}

The Columbia Plateau is unique because it is the youngest assemblage of flood basalts known. These lavas were poured out over an area of 200,000 square kilometers through dike feeders confined essentially to the eastern two-thirds of the plateau.

To the north, the older rocks of the Northern Cascades-Okanogan Highlands are broken into enormous north or northwest-trending grabens. The Cascade Range to the west consists of upwarped and accumulated piles of volcanic rocks and volcanic-derived sediments which owe their deformation, at least in part, to a time contemporaneous with the outpouring of the Columbia River basalts. 
The southern boundary is regarded generally as the large Blue Mountain anticline. The eastern edge of the plateau is defined by the Northern Rocky Mountains and several late Mesozoic batholiths in Idaho.

\section{BASALTS AND YOUNGER SEDIMENTS}

The Columbia River basalts in themselves are remarkable datum planes established in a geologically very short period of time as each flow poured out on the surface. Every flow, as it is studied, reveals the sum of all deformation to which it has been subjected since the time of its origin. For the oldest of these flows, this interval is approximately 17 million years. The youngest flows and interlayered sediments may reveal somewhat less deformation, indicating a continuation of stress conditions, whether they were sporadic or continuous.

Some examples of these youngest deposits and their ages are as follows:

Thorp gravels of Kittitas Valley

Ringold sediments

Tieton andesite

Palouse soil

Touchet beds

Glaciofluvial gravels

Ash beds from Cascade volcanoes
3.5 million years

700,000 to 1.5 million years

0.99 million years

50,000 to 60,000 years

10,000 to 30,000 years

10,000 to 30,000 years

6,000 to 12,000 years.

\section{DEFORMATION OF THE COLUMBIA PLATEAU}

The great bulk of the Columbia Plateau basalts was poured out over a 3-million year interval. The basalts were folded into a series of prominent anticlines known collectively as the Yakima Ridges. These ridges vary from 75 to $150 \mathrm{kilometers} \mathrm{in} \mathrm{length,} \mathrm{are} 2 \mathrm{kilometers} \mathrm{wide,} \mathrm{and} \mathrm{generally} \mathrm{trend}$ from north $55^{\circ}$ west to east-west. Most of the ridges bend to the southeast at their eastern ends. The Yakima Ridges are separated by 30-kilometer wide depressions known locally as the Quincy and Pasco Basins. The wide spacing of the ridges suggests that some measure of decollement, or gliding, has occurred at depth to account for such structures. 
Although the intervening synclines are covered in most places by younger, less deformed sedimentary beds, the structure of the basalts in the synclines is quite well known. At the Hanford Site, the continuity of basalt structures in the synclines has been verified by numerous deep drill holes and seismic lines that penetrated the overlying 100 meters or more of Ringold and glaciofluvial deposits. Thus, the general basalt structure at the Hanford Site can be determined with some degree of confidence.

The Yakima Ridges and associated structures to the south were not significantly deformed prior to early Pliocene time. Most deformation preceded the deposition of several units, such as the Tieton andesite (0.99 million years old) and the Thorp gravels ( 3.5 million years old).

To the west, between The Dalles and Arlington, northwest-trending faults have been dated by radiometric methods. They displace older Simcoe lavas (4.5 million years old) but do not displace the younger lavas (3.5 million years old). A considerable body of evidence suggests that the folding and faulting which produced structures such as the Columbia Hills anticline and The Dalles-Umatilla syncline resulted from the same Plio-Pleistocene deformation.

\section{FOLDING}

Crustal shortening (compression) may be estimated for the Yakima Ridges, or at least for that portion from the east-west section of the Columbia River up to and including the Saddle Mountains. This estimate is done by restoring the folds and faults to their original positions and measuring the difference between the deformed and undeformed distances across the folds.

Laubscher (1977) estimated the total translational compression in the above section to be on the order of three kilometers. This figure is based on estimates at each of the following localities: 
Columbia Hills anticline

Horse Heaven Hills

Toppenish Ridge

Rattlesnake anticline

Yakima Ridge

Umt anum Ridge

Manastash anticline

Saddle Mountains
300 meters of compression

200 meters of compression

200 meters of compression

300 meters of compression

400 meters of compression

600 meters of compression

800 meters of compression

230 meters of compression.

Major deformation began about eight million years ago and, for the most part, was completed between 3.5 and 4.5 million years ago. The strain rate, using a compressive shortening of three kilometers, is 3 kilometers/4 million years.

\section{FAULTING}

Certain segments of the long anticlinal ridges in the western Columbia Plateau show faulting along steeply dipping or overturned flanks of these folds. The fault displacement is difficult to determine, because the apparent offset can be confused with steeply dipping monoclines having little or no fault component. Also, the volcaniclastic interbeds are quite incompetent and absorb most of the differential movement during folding.

Some of the youngest faults are in the Kittitas Valley, which contains the city of Ellensburg. Approximately 20 kilometers northwest of Ellensburg, the Dry Creek fault, with a vertical offset of 50 meters, can be bracketed in time between the disturbed Thorp gravels ( 3.5 million years) and the undisturbed Kittitas drift $(120,000$ years $)$.

01der and much larger faults are concentrated in the northern portion of the Yakima Ridges. An example is Manastash Ridge, which shows a continuous fault for a distance of $50 \mathrm{kilometers}$ and a vertical offset of nearly 500 meters. This offset is the 1 argest in the area.

For some time the controlling structure for establishing seismic risk in the Hanford Site has been the Wallula Gap fault and its alignment with the Rattlesnake Hills-Badger Mountain folds. In 1977, a detailed stratigraphic 
and structural study was made of this structure, with special emphasis placed on the analysis of faults on trend with the structure. The new trench at Wallula Gap provided an excellent opportunity for studying the fault in detail. The Wallula Gap fault near Yellepit extends north $70^{\circ}$ west from the Columbia River for a distance of about four kilometers. The fault is 80 meters wide at its widest known place. It is interpreted as a scissors-type with normal faulting dominant, but the trench also reveals combinations of thrust faulting and drag folding on lesser scales. The displacement is approximately 50 meters. The age of displacement is pre-Kennewick fanglomerate (probably 13,000 years or more).

Between Wallula Gap and Badger Mountain to the northwest is a series of small, elongated domes that are discontinuous and, in places, tightly folded. Except for some local high-angle faulting at the southeast end, there is no evidence that this entire lineament is fault caused.

West of Wallula Gap the deformation is predominantly folding. The final movements along the faults were largely an accommodation to the forces that produced the folding. The stress regime is predominantly north-south compression. This tectonic regime extends westward to the Cascade Range.

East of Wallula Gap the mode of deformation is predominantly normal faulting. These normal faults lie en echelon and extend southeastward into the LaGrande graben. The stress regime for that area is apparently east-west extension.

The Wallula Gap-Rattlesnake structure has been studied in some detail, because it is critical for evaluating seismic and fault risk at the Hanford site. It also provides a transition zone between stress regimes.

The hypothetical Olympic-Wallowa lineament extending from the Strait of Juan de Fuca to the Wallowa Mountains has been discussed extensively in the literature. It is difficult, if not impossible, to trace this lineament across Puget Sound and the Cascade Range. However, a broad zone or lineament does exist from Cle Elum on the northwest to Wallula Gap on the southeast, a distance of $200 \mathrm{kilometers.} \mathrm{This} \mathrm{zone,} \mathrm{referred} \mathrm{to} \mathrm{as} \mathrm{CLEW,} \mathrm{varies} \mathrm{from} 13$ to 40 kilometers in width and is marked by the bending to the southeast of the 
eastern edges of the Yakima Ridges. Interpretations vary considerably. Bentley (1977) suggests that "multiple structures rooted in basement weakness zones form monoclinal faults at the surface." Laubscher (1977) postulates that it is "a right lateral en echelon shear belt which indicates deep-seated right lateral shear that exerts a torque on the base of partially decoupled surficial layers."

In any event, the prominent Yakima Ridges lose their identity at their eastern ends, where they become dispersed into many smaller and less conspicuous features.

\section{GRAVITY}

In 1977 all available gravity information on the Columbia Plateau and neighboring areas was brought together and analyzed. The Bouguer anomaly data were separated into regional and residual components. When the regional Bouguer gravity data was plotted on a map, the horizontal gradient was low in the central portion of the Columbia Plateau and relatively high along the edges of the plateau. It is interesting to note that the steep gradient near Lake Chelan and in northeastern Oregon around Milton-Freewater are two of the most seismically active regions in or near the Columbia Plateau.

The deviatoric stresses calculated from surface anomalies and using several model variations may provide an estimate of stresses at depth. The maximum deviatoric stress at depth may reach 100 to 200 bars. These values are sufficiently large to localize earthquakes.

\section{STRESS FIELD}

Several approaches to stress field interpretations are available. Topographically, the Yakima Ridges represent a series of roughly east-west trending anticlines and synclines that suggest a considerable shortening in a north-south direction.

Recent microearthquake investigations show that a north-south compression is consistent with virtually all first motion data. Three composite focal mechanisms in the vicinity of the Hanford Site indicate reverse faulting on east-west striking planes. 
Weston Geophysical Research (1977) interpreted the maximum compression for each of the microearthquake solutions to be near horizontal and oriented north-south. The minimum compression axis varies over a wider range but is generally within $45^{\circ}$ of vertical.

Waitt (1978) recently pointed out that, in the area of the Yakima Ridges, a gentle north-south compression has persisted from the Miocene Epoch to the present. This does not apply to the upper Tertiary (Cascade Range) of western Washington and Oregon. Nor does it apply to the eastern portion of the Columbia Plateau where, during extrusion of the basalts, considerable east-west extension has occurred.

Data from the deep well at Rattlesnake Hills suggest a subsidence of 0.3 meters $/ 5000$ years during extrusion of the lavas.

During the time the Ringold sediments were deposited, from 50,000 to 1 million years ago, there was a general basining. This basining is evidenced by the decreasing dips upward in the Ringold sediments. Basining may still be occurring.

In general, the north-south compressive stress appears to have been applied over the entire crustal thickness, because parallel stress axes are found for very shallow focus earthquakes as well as for events occurring in the lower crust. Local variations in the orientation of the minimum compressive stress axis, leading to varying amounts of horizontal slip, suggest that there are local changes in east-west confining stress. These changes may be related to local geologic variations in tectonic stress response within the multilayered basalts or in the crustal basement lying beneath.

\section{CONCLUSIONS}

The present structures within the Columbia Plateau represent the sum of deformation that has occurred during the past 16 million years.

The time interval of significant deformation was between four and eight million years ago. During this interval, three kilometers of crustal shortening occurred between the Columbia Hills anticline and the Saddle Mountains. 
Basining occurred on a broad scale at the time the basalts were extruded. The general area continued to subside as the major rivers united in the Pasco Basin. Low regional dips in the Ringold sediments suggest that basining is still going on, but it is on a scale that is difficult to measure.

The maximum stress is essentially north-south in the area of the Yakima Ridges. The minimum stress varies considerably on either side of vertical. Such has been the stress regimen for many millions of years, and there is no known evidence which indicates that it will change in the immediate future.

The greatest yielding to stress has been in Manastash and Umtanum Ridges, $f$ ar to the northwest of the Pasco Basin.

The manner of stress relief is dependent on many factors, including the physical properties of the rocks involved and the geologic structures. Many interbeds of volcanic-derived sediments and lake sediments are incompetent under stress and yield differentially when compared to the more brittle basalts.

In general, the major faults in the Yakima Ridges are well known. Geophysical and remote sensing techniques have indicated areas where obscure or potential faults may exist.

Structural evidence indicates that waste disposal sites would be more favorably located in the basins. They should be removed as $f$ ar as possible from the more intensely deformed areas to the northwest (e.g., Manastash Ridge) and from the more active areas to the southeast (e.g., MiltonFreewater).

\section{REFERENCES}

Bentley, R. D. 1977. "Stratigraphy of the Yakima Basalts and Structural Evolution of the Yakima Ridges in the Western Columbia Plateau. "I In Geologic Excursions in the Pacific Northwest, eds. E. H. Brown and R. C. Ellis, pp. 339-389. Western Washington University, Bellingham, Washington.

Laubscher, H. 1977. Structural Analysis of Post-Yakima Deformation, Columbia Plateau. Report prepared for WPPSS. 
Waitt, R. B. 1978. Post-Miocene Stratigraphy and Tectonism of Parts of the Great Columbia Plain and Adjacent Cascades, Washington. Prepared for a Rockwell Workshop in Seattle, Washington.

Weston Geophysical Research. 1977. "Evaluation of Microearthquake Activity in Eastern Washington." WPPSS Amend. 23 2RJ. $21 \mathrm{p}$. 


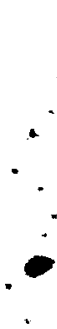

.

.

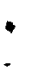




\section{CHAPTER XII}

\section{EVIDENCE AND THEORY FOR THE PREDICTION OF TECTONIC ACTIVITY \\ IN THE BASIN AND RANGE PROVINCE OF NEVADA AND UTAH FOR THE NEXT \\ ONE MILLION YEARS \\ E. M. P. Lovejoy}

University of Texas

\section{PURPOSE AND SCOPE}

The primary purpose of this report is to define probabilities for earthquake activity within the Basin and Range Province of Nevada and Utah for the next one million years. Considerable research effort has also been concerned with Cenozoic Basin and Range tectogenes is as a whole. A new model of Basin and Range tectogenesis that differs significantly from the numerous, previously proposed theories is presented.

This report is divided into three portions. The first is a discussion of the "classic" interpretations and theories of Basin and Range tectonics as found in the published literature.

The second portion of the report summarizes the author's evidence for a temporal history of the Basin and Range, differing in many details from interpretations currently in vogue. The rationale for predicting seismic activity is also presented. Finally, the new tectonic model is defined and expanded to the point of providing a unifying framework for the tectogenesis of the interior American Cordillera.

The third portion of the report presents predictions and probabilities for earthquake activity in the Basin and Range of Nevada and Utah for the next one million years. 


\section{CONCLUSIONS}

Briefly, major conclusions of the report are:

1. Important seismic activity in the next one million years will be restricted to the Intermountain Seismic Belt.

2. Minor seismic activity in the same period will be restricted to the Nevada Seismic Belt, Sierra Nevada front, and Reno-Yellowstone lineament.

3. There will be seismic inactivity in the same period in the rest of the Basin and Range Province except locally along high mountain frontal fault zones. In these zones, isostatic unloading will produce slow, secular, mild seismic activity for many millions of years to come.

\section{SUMMARY OF THE DEVELOPMENT OF THEORIES OF BASIN AND RANGE TECTOGENESIS}

By 1943, three main explanations had been advanced (in various combinations) to account for the present topographic relief in the Basin and Range:

1. The ranges and valleys are limited by normal faults caused by tensional forces.

2. The ranges and valleys are limited by reverse faults, or by superficial normal faults caused by regional compression.

3. The valleys have been formed by erosion of a folded region (by analogy to the Valley and Ridge Province of the Appalachians).

Current, widely accepted knowledge and interpretations of Basin and Range structural relations and tectogenesis can be summarized as follows:

The Basin and Range physiographic province has long been recognized as a site of Cenozoic crustal extension and volcanism. More recently, geophysical investigations have shown that much of this region can be sharply distinguished from adjoining provinces by its heat flow, tectonism, and crustal and upper mantle structure. These things mark this region as unusual among continental areas. That part of the province for which the latter characteristics can be demonstrated best is the Great Basin of Nevada, western Utah, and southern-most Idaho. 
The Great Basin is a broad zone of almost evenly spaced semiparallel mountain ranges which trend north-northeast and are bounded on one or both sides by steeply dipping normal faults. Most of the ranges were formed by faulting since Miocene time but some faulting began as early as Eocene to 01igocene time. This faulting represents major late Cenozoic crustal extension. Estimates of the total extension range from 50 to $300 \mathrm{~km}$. It has been noted that right-lateral, strike-slip motion is prevalent on faults along the western boundary of the region.

In contrast to the nearly uniform Cenozoic deformation across the region, current and historic seismic activity is concentrated along certain bands. The seismicity forms two belts: one follows the western boundary of the Basin and Range Province and the Sierra Nevada, the other follows the Colorado Plateau and Basin and Range boundary on the east. The historic and instrumentally recorded seismicity shows that these two belts have dominated the seismicity of the entire region for the past hundred years. Recent studies have shown that both zones are relatively narrow, concentrated bands of seismicity, even at the micro-earthquake level.

The late Cenozoic of the western United States was marked by an abrupt change in style of volcanism from the earlier calc-alkaline type to basaltic volcanism associated with Basin and Range type normal faulting. This transition began in late 0ligocene in the southeastern part of the western United States and moved northward through Miocene, Pliocene, and Quaternary time.

A second space-time pattern of volcanism in the Great Basin has been observed. From an extensive collection of $K$-Ar age determinations for silicic igneous rocks, it has been shown that volcanism began about 40 m.y. ago in east-central Nevada. Since that time the zone of most intense silicic volcanism spread laterally outward from a central core region, forming successively larger rings of younger igneous rocks. The youngest ring is located at the present margins of the Great Basin. The rate of outward migration is asymmetric; it has been much more rapid to the west than to the east. 
The two zones of intense activity on either margin of the Great Basin are in positions which coincide with the zones of most recent volcanic activity. The zones of most recent volcanism and the present seismic belts lie directly above the sharp zones of lateral transition in crust and upper mantle structure. This situation implies that the anomalous low velocity, high attenuation zone in the upper mantle beneath the Great Basin has spread outward progressively with time.

The above observations can be explained by regarding the Great Basin as an ensialic interarc basin. From age determinations and sedimentation patterns, it has been deduced that the crust in interarc basins is basaltic and younger than that of adjacent regions. From this deduction and other evidence, it has been suggested that the interarc basins are sites of crustal extension produced by the intrusion of a rising diapir of partially molten material originating from the downthrust lithospheric slab beneath the basin.

Four key features of the Basin and Range are still incompletely resolved:

1. the superposition of strike-slip and normal faults

2. the significance and origin of the low-angle normal faults

3. the relation of the fault system to the deep crust and upper mantle

4. the genetic, spatial and temporal relation between the fault patterns and volcanism.

TSR, THE NEW TEMPORAL HISTORY, AND THE NEW TECTOGENETIC MODEL

The major problem of predicting tectonic activity in the Basin and Range for the next million years is primarily a matter of determining the rates of tectonic activity in the past and extrapolating those rates for the future.

Key structural subjects used to determine tectonic rates (i.e., the time of inception, the time of major slip, and the amount of slip of basin range boundary faults) are subject to considerable disagreement. Although there are now thousands of precise rock dates and hundreds of detailed geologic maps of large parts of the Basin and Range Province, there are no published efforts which attempt to compile these data into a unified concept of time rate of basin range boundary faulting. Such a compilation is offered here. 
The Time-Slip Relationship (TSR)

The Time-Slip Relationship (TSR) is a means of quantifying secular rates of fault slip. The TSR relates two measurable variables, geologic time and fault slip. It shows the relationship between the absolute geologic age, in years, of a rock (abscissa) and the amount it has slipped along a fault (ordinate). An extrapolation of the curve determined by those data for the next one million years would be expected to show the time rate of fault slip on that fault. This time rate could be used as an indication of the tectonic activity of the region along the fault.

The slope of the curve which describes the TSR at the present time for a given fault or a given area and its slope for the next one million years show the present and projected time rate of slip. Although the data for the past few million years are insufficient to permit resolution of predicted rates for the next million years, data obtained over a period of time equivalent to that of the Cenozoic Era, 65 m.y., ought to be sufficient to permit extrapolation forward one million years.

The TSR is based on published literature and maps. The information from these sources is not all of equal value and reliability. Judgment must be made concerning some data. Radiometric ages of volcanic rocks are assumed to be correct, although not all rocks can be precisely dated. In the case of an age range, a horizontal line called an isodate must be used.

Most map data are acceptable, although locally not enough data are available, particularly those dealing with fault slip values.

Because not all slips can be accurately determined, a range must be used. In cases for which the slip range represents a rock of a given precise age, then an isodate is used. However, in cases for which the slip range and age range are broad, then an areal distribution consisting of a vertical box bounded by two horizontal isodates must be used. Obviously, where a precise date and a precise slip are known, the data are shown by a point.

The TSR can be determined for a single fault, for a group of faults in a region, for a given fault along different parts of its length, or for the entire Basin and Range Province. 
The TSR for a region may be represented by a band. The upper and lower limits of this TSR band may be considered the limits of the faulting rates. Extrapolation of the upper and lower limits of the TSR from the present to one million years in the future should be considered as an indication of the tectonic stability of the pertinent region.

New Temporal History

The new temporal history, as envisioned by the author, states that basin range faulting began in the Paleocene, waxed in the Paleogene, culminated in the 0ligocene, and waned in the Neogene.

The new temporal history is suggested by several separate and distinct lines of evidence.

The first line of evidence consists of fault histories. The history of development of at least three major faults (the Hurricane, Grand Wash, and Eastern Boundary fault zone of the Franklin Mountains) suggests that basin range faulting developed early in Cenozoic time and was about three-fourths finished by the end of 01 igocene.

The second line of evidence is concerned with caldera localization in basin ranges. The localization of Paleogene-early Neogene calderas in already formed basin ranges suggests that basin ranges must have existed at the time of caldera development.

The third line of evidence consists of the TSR data. TSR data for the basin range indicate that oldest rocks have been offset most and youngest rocks have been offset least, all exclusive of the eastern and western seismic belts.

\section{NEW TECTOGENETIC MODEL}

The new model is based on interpretations of lithosphere-asthenosphere relations beneath the Basin and Range.

Observations indicate that basin range faults include vertical, high angle reverse, and high angle normal faults. These boundary faults have great throw and were high angle; it is concluded that the faults pass through the 
crust and lithosphere and penetrate into the mantle and asthenosphere. It is further concluded that flow of asthenospheric material below the base of the range block was allowed.

Current concepts of plate tectonics assume that oceanic crust can penetrate deeply into sub-continental mantle. There must, therefore, be a considerable relief at the base of the lithosphere. Obviously, if basin range faults have throws of tens of thousands of feet (up to ten kilometers), then those faults are extremely important structures in the crust. Although it has been widely believed that basin range faults curve at depth and do not penetrate to the base of the lithosphere, this interpretation should be re-evaluated. Lithosphere-Asthenosphere Interfacial Relief

There must exist at the base of the range a "topographic high" in the crust-mantle or lithosphere-asthenosphere interface. This topographic high would be bounded by a step. The topographic high can be termed a "cupola," the step next to it a "keel." Topographic relief at the crust-mantle interface might be on the order of kilometers beneath the Franklin Mountains, because the range has been elevated about ten kilometers along the Eastern Boundary fault zone and the crust is about $25 \mathrm{~km}$ thick. Topographic relief at the lithosphere-asthenosphere interface might be less because of plastic flow.

Because the lithosphere-asthenosphere interface is a function of temperature, the elevation of this interface has changed with time. It was higher in the early Cenozoic when crustal magmatism was widespread and intense. Thus, early in the Cenozoic, the base of the lithosphere may have been close to the base of the present crust.

Concepts of plate tectonics applied to subducting lithospheric plates suggest that magma is derived from subducted material. This material may rise as magmatic globules through the asthenosphere, into the mantle or the lithosphere, and finally up into the crust. 
With shear of the lithosphere over the asthenosphere, the "cupola" became an inverse sump for rising magma globules, scraped off by the keel as the lithosphere swept across the rising globules in the asthenosphere. Furthermore, the depressed basins were corroded by the streaming asthenosphere. Mechanism of Basin Range Formation

A11 of the above can now be summarized in a mechanism of basin range formation.

First, Paleocene lithospheric compression (probably associated with plate tectonics) formed reverse faults in the lithosphere.

Second, these lithospheric reverse faults bounded basin range blocks on one side. The fault was marked at the base of the lithosphere by a topographic relief, the inverse of that at the surface. "Cupolas" began to form beneath ranges. The major faults outlined a "keel" at the edge of the lowered basin block.

Third, lithospheric slip across the asthenosphere and skimming off by the "keel" of magmatic globules rising through the asthenosphere caused an accumulation of these rising globules beneath the "cupolas" of the ranges.

Fourth, the long-continuing lithospheric compression (plate-tectonics induced) coupled with the vertical compression associated with vertical buoyancy of sub-range magma which had accumulated in the "cupolas" produced a plastic reaction in the range block. The range rose like a watermelon seed squeezed between the fingers. Upthrusts developed on the smaller-throw boundary fault zone.

Fifth, the range block was plastically squeezed upward in late Paleogene, caught in the jaws of a lithospheric vise, and the brittle surficial rock (the range) began to tilt as a result. Seventy-five percent of faulting was finished at the end of the Paleogene. The range now has a granitic root.

Sixth, uplift continued in the early Neogene, and major tilting began and accelerated. In the present there is waning uplift but continued rotation. Ninety-five percent of the uplift was finished by the end of the Miocene. 
Sea Floor Structure and Basin Range Structure

Magnetic, bathymetric, and seismic maps of the sea floor in the eastern Pacific show a general north-south trend with alternating highs and lows. Although the widths of the magnetic highs and lows are a function of spreading rates and magnetic reversal times, seismic profiles and bathymetrics suggest that there is a north-south grain to the structure of the ocean floor. This structure has been interpreted to be the result of intrusive emplacement parallel with the spreading center ridge.

Seismic profiles made across the ocean floor show crest-to-crest distances on the order of three or four major ridges per degree longitude to five or six lesser ridges per degree. Bathymetric profile distributions show that major highs are, on an average, about $25 \mathrm{~km}$ apart. Numerous east-west transform faults also exist.

Examination of geologic maps of basin ranges in Nevada and Utah shows that there are about three to four ranges per degree of longitude. The average distance between ranges is about 25 to $30 \mathrm{~km}$. East-west alignments have been noted in Nevada, Utah, and Oregon.

It is suggested that the upper part of the mantle beneath the Basin and Range Province has a north-south structure inherited from an early sea floor spreading regime. The vertical and north-south inhomogeneities, the east-west cross structures, and the spacings are all similar. The faults probably penetrate through the crust and into the lower lithosphere or upper mantle. Thus, inheritance of structure from the mantle upward into the crust is probable. Sumary of the New Tectogenic Model and Basin and Range Tectonic Activity

Basin and Range tectogenesis and Colorado Plateau epeirogeny were primarily Paleogene, followed continuously by minor Neogene modification. The wellknown Rocky Mountain uplifts and Basin Range-type mountains of southwestern Montana were formed in Paleogene and modified in Neogene. Thus, all important elements of the interior American Cordillera share in a common timing of major Paleogene development followed by continuous Neogene modification. Paleogene horizontal compression, which formed reverse, faults was followed by local (iso-static) Neogene vertical compression, which formed normal faults 
(interpreted by other tectonicists as evidence of regionally horizontally distended crust). Late Paleogene silicic magma accumulated beneath early Paleogene-formed Rocky Mountain brachyanticlinal uplifts, Basin Ranges and the entire Colorado Plateau. This silicic magma caused the minor but continuous Neogene isostatic vertical tectonic modifications (and associated basin range normal faults) of those Paleogene compressional uplifts. Basin ranges are simply slight modifications of the characteristic structure of Rocky Mountain uplifts, but they occur in a region of thinner crust. Currently accepted theories require primarily a discontinous mid- to late-Neogene horizontal crustal distension and Basin Range-Colorado Plateau uplift, separate and distinct from the Paleogene tectonism. These theories have been predicated on a different timing and interpretation of the significance of Neogene normal faults that bound uplifts. The present concept seems to unify the tectogenesis of the interior American Cordillera.

Modern seismicity in the Basin and Range is mainly isostatic in origin, and a relatively small amount of it is due to tectonism. Regional tectonism in the Basin and Range Province is essentially moribund, except along certain active zones. Elsewhere, isostatic adjustments and slowed tectonic elastic residual stresses are the current mechanisms which produce earthquakes.

The Basin and Range Province of Nevada and Utah is now undergoing mainly decaying isostatic adjustments, as ranges are denuded and basins are loaded. Negligible Pleistocene earthquake activity might have been the result of relatively more rapid denudation rates accompanying freeze-thaw generation of talus, glacial debris, and alluvium. Thus, the higher the mountain, and the more readily produced the talus and alluvium, the greater the expected seismic activity. It has been assumed that there is greater seismic activity in higher mountains because they have been greatly uplifted recently. On the contrary, their very height, in conjunction with the Pleistocene climates, has been an agent which has aided in the production of the recent scarps at their bases. Perhaps high seismicity along the Intermountain Seismic Belt is caused by high erosion rates. There is a close relationship between seismicity and erosion 
rates in the region between Cedar City and Hurricane, Utah, along the Hurricane Cliffs and fault and along the high wasatch front along the wasatch fault. Perhaps the lesser seismicity along the Sierra Nevada front is tied to lower erosion rates. The rates of erosion on the Sierran intrusive rock are lower than those in the Intermountain Seismic Belt. Hence, seismicity is less along the Sierran granitic fronts than in the Intermountain Seismic Belt. Recurrence of a pluvial climate with the formation of large intermountain lakes may also isostatically induce recurrence of mild earthquake activity along basin range faults.

This relationship does not seem to apply to the Nevada (118th Meridian) Seismic Belt of the Reno-Yellowstone belt. The Nevada Belt seismicity may be tectonically related to shear along the San Andreas fault system. The Reno-Yellowstone lineament seismicity may be magmatically generated.

The TSR evidence presented in this report indicates that current and future earthquake activity in the Basin and Range Province of Nevada and Utah is and will be limited primarily to the Intermountain Seismic Belt, the Nevada Seismic Belt, the Sierra Nevada front (in California), and the RenoYellowstone lineament. The Intermountain Seismic belt is the most active of these, and strong earthquakes will continue there for at least one million years. The Nevada Seismic Belt is less active, and mild earthquakes will continue there for at least one million years. The eastern front of the Sierra Nevada is active; earthquakes will probably continue there for many millions of years. The Reno-Yellowstone lineament appears to be tectono-seismically inactive at the present time (except for its junction with the Nevada Seismic Belt). However, in the time frame considered for this report (one million years into the future), there may be magmatically-induced seismicity at its northeast end. There will probably be mild, secular, and infrequent earthquake activity along high mountain fronts if there is a recurrence of Pleistocene-type climate.

The remainder of the Basin and Range Province is seismically quiescent. Tectonic activity has essentially ceased. 
PROBABILITIES FOR EARTHQUAKE ACTIVITY IN THE BASIN AND RANGE

PROVINCE OF NEVADA AND UTAH FOR THE NEXT ONE MILLION YEARS

This analysis is based on three assumptions:

1. There is a direct, linear relationship between earthquake magnitude and the height of fault scarp produced by the earthquake.

2. TSR data for a fault can be extrapolated for the next one million years.

3. TSR data and fault scarp height:magnitude data can now be combined.

Extrapolated amount of throw for the next one million years will be developed as the result of earthquakes of at least $M=6$.

1. Scarps 5 to $10 \mathrm{~m}$ high are common in the Basin and Range Province. The scarp on the east side of the Franklin Mountains is about $13 \mathrm{~m}$ high.

Scarps have been seen about $15 \mathrm{~m}$ high. Therefore, based on meager anecdotal evidence it is assumed that an earthquake $M=6$ will produce a fault scarp $1 \mathrm{~m}$ high, an earthquake $M=7$ will produce a scarp $7 \mathrm{~m} \mathrm{high,} \mathrm{and} \mathrm{an}$ earthquake $M=8$ will produce a scarp $14 \mathrm{~m}$ high.

2. TSR data suggest that rocks as old as 6-7 m.y. old in the Nevada Test Site - Nellis Air Force Range (NTS-NAFR) region have been displaced $10 \mathrm{~m}$, for an average rate of $1.5 \mathrm{~m} / \mathrm{m} . \mathrm{y}$.

TSR data for the Sierra Nevada front at Sonora Pass can be tabulated as follows:

$\begin{array}{ll}800 \mathrm{~m} \text { in } 9 \mathrm{~m} . \mathrm{y} . & \text { average rate } 89 \mathrm{~m} / \mathrm{m} . \mathrm{y} . \\ 80 \mathrm{~m} \text { in } 0.7 \mathrm{~m} . \mathrm{y} . & \text { average rate } 113 \mathrm{~m} / \mathrm{m} . \mathrm{y} . \\ 30 \mathrm{~m} \text { in } 10.07 \mathrm{~m} . \mathrm{y} . & \text { average rate } 430 \mathrm{~m} / \mathrm{m} . \mathrm{y} . \\ 8 \mathrm{~m} \text { in } 0.02 \mathrm{~m} . \mathrm{y} . & \text { average rate } 800 \mathrm{~m} / \mathrm{m} . \mathrm{y} .\end{array}$

At McGee Mountain and at Mt. Rose, the data presented suggest that there has been relatively little uplift in the past few million years.

TSR data along the Hurricane fault indicate that there has been about $400 \mathrm{~m}$ of throw in $1 \mathrm{~m} . \mathrm{y}$. This appears to be the maximum rate of movement in the Intermountain Seismic Belt. 
TSR data for the Nevada Seismic Belt suggest about 30 to $60 \mathrm{~m}$ of throw in the past $6 \mathrm{~m} . \mathrm{y}$. , for an average rate of 5 to $10 \mathrm{~m} / \mathrm{m} . \mathrm{y}$. However, in the southern end of the belt near the Garlock fault and in the intersection with the Reno-Yellowstone lineament, there appears to be a higher seismicity and fault activity which is not documented herein.

3. TSR data can be combined now with the fault scarp height: magnitude relationship (which implies that faults $M=6$ will produce fault throws of about $1 \mathrm{~m}$ high, $M=7$ about $7 \mathrm{~m}$ high, and $M=8$ about $14 \mathrm{~m}$ high).

In the NTS-NAFR region, the rate of movement of $1.5 \mathrm{~m} / \mathrm{m} . \mathrm{y}$. suggests that there might be on ly one earthquake $M=6$ in any given fault segment in this region, primarily along basin range boundary fault zones and possibly along the only known fault scarp, the Yucca fault.

In the Sierra Nevada frontal fault zone at Sonora Pass, where the present rate is $800 \mathrm{~m} / \mathrm{m} . y_{\text {., }}$, there might be some combination of the following: $800 \mathrm{M}=6$; $115 M=7$; or $60 M=8$ earthquakes in any given segment of the zone in the next $1 \mathrm{~m} . y$. This rate might not apply along all the Sierra Nevada front, and earthquakes might be much less prevalent elsewhere.

In the Intermountain Seismic Belt, especially along the Hurricane fault zone, where the rate of faulting seems to be at a maximum for that belt, a rate of $400 \mathrm{~m} / \mathrm{m} . y$. suggests that there might be about $400 M=6,60 M=7$ or $30 M=8$ earthquakes in any given segment of the fault zone in the next 1 m.y., most of which would probably occur near regions of high relief.

Along the Nevada Seismic Belt (118th Meridian), where the average rate of throw is 5 to $10 \mathrm{~m} / \mathrm{m} . \mathrm{y}$., there might be expected 5 to $10 M=6$ or $1 M=7$ earthquakes along any given segment of the zone in the next 1 m.y.

Comparison of the above values with the frequency of reported events $(M=6)$ in the Intermountain Seismic Belt during the past century reveals that the historical frequency of earthquakes is 1 to 2 orders of magnitude greater than the frequency extrapolated from TSR evidence. 


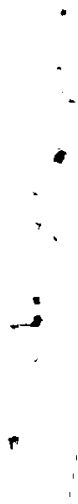


CHAPTER XIII

PROBABILITY OF EXPECTED CLIMATE STRESSES IN

NORTH AMERICA IN THE NEXT ONE M.Y.

\author{
G. Kukla
}

Occurrence probabilities were investigated for future climate related stress events in western North America that could contribute to a breach of a radioactive waste repository. The climatological stress events with the largest expected disruptive potential relate to changes in precipitation, evaporation, and runoff. Their possible impact depends closely on various geographic factors, defined to a large degree by the location of a site.

Probabilities are given for a scenario that depicts a continuation of the present level of technology or a collapse of technocratic civilization within the near future, followed by a natural climate variability. This climate variability is expected to continue into the future, following past climate patterns. Climate fluctuations are controlled by perturbations of the Earth's orbital elements.

An alternative scenario predicts a peaceful perpetuation of technocratic civilization, which will bring along a complete stabilization of climate and a complete elimination of climate related disruptive events.

C.limates one million years ahead were predicted upon the assumption that the pattern of natural climate variability observed during the past million years will continue. The impact of man's industry and land use on climate was considered only to a limited degree. This consideration involved assessment of the effects related to present and near-future technologies. Possible climatic impacts of a misguided, highly advanced, future technologic civilization were not taken in account. The climatic impact of a world-wide nuclear war is another factor that was not considered. 
The probability, magnitude, and frequency of occurrence of future climate extremes were based on reconstructed records of past climate variations. Fluctuations of oxygen isotopes in the foraminiferal tests recovered from the world oceans were taken as the most complete and reliable records of global climate changes. The ratio of oxygen isotopes $0^{18}$ and $0^{16}$ in buried benthic foraminiferal tests is controlled predominantly by fluctuations in the total volume of ice deposited on 1and. This record is almost independent of the geographic location of a studied site. A piston core, V28-238, is considered to be a type locality of the $0^{18} / 0^{16}$ stages. For stratigraphic purposes, the benthic $0^{18}$ record is interchangeable with that of planktonic foraminifers.

Boundaries separating especially pronounced isotopic maxima from exceptionally pronounced minima have been called terminations. The segments bounded by two consecutive terminations are labeled glacial cycles. Terminations are numbered by Roman numerals in order of increasing age.

The $0^{18}$-rich planktonic foram shells may result either from low sea surface temperatures or from the existence of a large volume of ice on 1 and. Thus, the odd numbered stages with relatively low proportions of $0^{18}$ record intervals of reduced global volume of ice, and/or alternatively of a relatively warm sea.

In theory, the $0^{18} / 0^{16}$ ratio in forams should provide an accurate measure of past ice volume. However, the resolution of the method is limited by a number of factors, which include delay in ocean mixing, varying sedimentation rates, changing sampling intervals, etc. Precision greatly decreases with age, mainly due to the effect of sediment mixing, burrowing, redeposition of shells into younger sediment, selective dissolution, etc. As a result, the relative peak-to-peak amplitudes of correlative stages in different cores diverge to a significant degree. At present, the shapes of $0^{18}$ curves, rather than the absolute values of isotopic ratios, are used for stratigraphic interpretations. 
There are eight completed glacial cycles, namely B through I, and nine terminations, I through IX, in the last epoch of normal polarity. This epoch lasted approximately 0.7 million years. There are ten completed glacial cycles, B to K, and eleven terminations, I to XI, in the past 0.9 million years following the Jaramillo normal polarity event. 0scillations of the ice volume, as recorded by the $0^{18} / 0^{16}$ ratio within each glacial cycle, seem to generally follow a sawtooth pattern, progessing from an early minimum to a late maximum. Apparently the glaciers have grown in steps that were interrupted by temporary regressions. The $0^{18}$ oscillations give no indications of where the ice was deposited and where the retreats took place. It remains unclear whether the changes of ice volume proceeded in phase or out of phase between the two hemispheres or between the North American and Eurasian continents. In each of the best known youngest glacial cycles, $B$ and $C$, five significant secondary oscillations took place.

Within the past one million years the general shape and amplitude, as we 11 as the internal structure of the $0^{18}$ fluctuations, remained approximately unchanged. This conclusion takes into account the limited accuracy of available data. Consequently, the climate history during each one of the former glacial cycles $C-J$ is likely to have displayed about the same degree of complexity as the late Pleistocene glacial cycle B (10-127K).

Within the precision 1 imits of the $0^{18}$ method, the warm peaks of odd numbered stages 1 to 21 (except stage 3) all seem to approach a closely similar level. This fact indicates that the global ice volumes and/or sea surface temperatures in peak interglacials were similar to those of today. It also indicates that during the past $0.9 \mathrm{million}$ years, there were at least nine episodes with global climate comparable to the present one. These episodes are labeled interglacials.

It was assumed that gross climate changes result from perturbations of the Earth's orbital parameters. This assumption is almost a general consensus of paleoclimatic workers. Astronomic Climate Index (ACLIN) was developed in order to predict the gross climate states from relatively well known astronomic variables. ACLIN was calibrated and tested against the radiometrically 
dated paleoclimatic evidence from the past 0.25 m.y. Four principal global climate states were recognized: interglacial, temperate interstadial, interstadial, and stadial (ordered from warmest to coolest). Their probability of occurrence was found from analys is of various paleoclimatic records from the past 150,000 years. The probability of each of the four states listed above was found to be $0.10,0.16,0.08$, and 0.66 , respectively. The average duration of temperature intervals (interglacials and interstadials) came out to be 10,8 , and 4 millenia, whereas that of stadials was found to be 8-16 millenia.

The ACLIN index, considered a reliable predictor for at least the next $10^{4}$ years, defines the timing of the cold and warm gross natural peaks. Higher ACLIN values correlate with a warmer natural global climate. ACLIN is computed after the formula:

$$
\alpha=\left|\frac{\omega_{t}-180}{90}\right|+\varepsilon_{t} 1-22+\frac{10^{3} e^{2}}{2}
$$

where $\omega_{t}=$ longitude of the perinelion at the time $\underline{t}$

$\mathrm{e}=$ eccentricity at the time $\mathrm{t}$

$$
\begin{gathered}
\varepsilon_{t} 1=\text { obliquity at the time } \underline{t}^{1} \text { defined by } \\
t^{1}>t \text { in years B.P. } \\
t^{1}<t \text { in years A.P. } \\
\omega_{t}{ }^{1}=\omega_{t}-90 \\
\left|t^{1}-t\right|=\text { minimum. }
\end{gathered}
$$

The response of environment and $\mathrm{climate}$ in the Basin and Range province of the western U.S.A. to those global fluctuations was reconstructed from various sources. These sources include traces of past lake levels, flood deposits, glacier moraines, pollen records, and rodent middens.

The reconstructions needed in the study were updated and critically reviewed at an ad hoc workshop conference in Reno, Nevada. Extensive compilation of the results of former research was also prepared. Even so, large 
uncertainty remains, especially concerning paleoclimatic events older than about 30,000 years. This uncertainty exists because geologic records covering such older intervals are scarce and incomplete. Also, most of the existing records have not yet been studied in sufficient detail.

The most remarkable environmental change that affected the Basin and Range province in the Late Pleistocene was the filling of closed basins with large freshwater lakes. The largest of these lakes were Lake Lahontan and Lake Bonneville. The highest levels in these lakes, accompanied by the corresponding rise of groundwater levels, were attained shortly before the end of the last full glacial episode, between 13,000 - 11,000 years ago. Relatively high levels were maintained during most of the stadials. Maximum rates of lake level rise and drop did not substantially differ from the rates observed in historical times.

Probability $\left(L_{m}\right)$ of a site located within the closed basin to be flooded is high and is a function of:

$$
L_{m}=f\left\{c, s, z_{0}, z_{1}, r\right\}
$$

where

$$
\begin{aligned}
c & =c \text { limate state } \\
s & =\text { site surface elevation or location } \\
z_{0} & =\text { present lake or basin bottom area } \\
z_{1} & =\text { elevation of maximum Late Pleistocene lake leve } 1 \\
r & =\text { relief factor quantifying geomorphic characteristics. }
\end{aligned}
$$

High lake levels were attained, mainly due to decreased evaporation and increased runoff from neighboring snow covered or glaciated mountains. Increase of average annual precipitation in glacial times was, by a factor of $I_{B}$, relatively minor.

$$
\text { Probability } \begin{aligned}
I_{B}= & f\left\{c, d_{m}, r\right\} \\
\text { where } & =\text { climate state characterized in terms of } P_{s} \text { or of } P_{\alpha} \\
d_{m}= & \text { distance of a site from a major body of water in the } \\
& \text { direction of dominant winds } \\
r= & \text { regional factor. }
\end{aligned}
$$


Most authors estimated the annual average precipitation over much of western America to be between 1.2-2.0 times that of the present average precipitation.

The probability of a site in the Basin and Range province being directly covered by a glacier is very small and is confined to geographically defined areas.

Probabiity (G) of occurrence of a permanent ice cover on site can be expressed as:

$$
G=f\left\{c, s, z_{p}, z_{g}, z_{d}, z_{s}, h_{u}, d_{d}, r, \gamma, d_{m}\right\}
$$

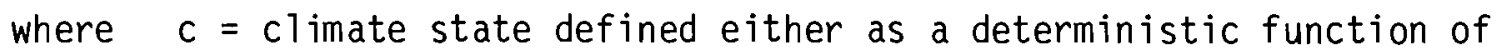
ACLIN $\left(P_{\alpha}\right)$ or as a result of stochastic distribution $\left(P_{S}\right)$

$z_{s}=$ elevation of the present regional orographic snowline

$z_{p}=$ elevation of Late Pleistocene snowline

$z_{g}=$ elevation of the glacier terminal

$z_{d}=$ elevation of the regional dominant peak

$s=$ site surface elevation

$d_{d}=$ distance of site to dominant peak

$h_{u}=$ uplift or subsidence; vertical departure from present

$r=$ relief factor

$\gamma=$ slope exposure parameter

$d_{m}=$ distance of a site from a major body of water in the direction of dominant winds.

The three key variables are $c, z_{p}$, and $d_{d}$. Uplift $h_{u}$ becomes important only on longer time scales.

Groundwater levels will fluctuate in response to changing evaporation/ precipitation ratios, runoff seepage from pluvial lakes, etc.

The interval of most abundant moisture was $11-13 \mathrm{~K}$ years ago. The departure of effective evaporation from today's value was estimated variously from 
$40 \%$ to $70 \%$. Insufficient data are at hand to justify a separate trial or probability functions for this variable. We imply that the groundwater table moved synchronously with the lake level changes, and that similar relationships will hold in the future. Thus, fluctuations of groundwater tables can be predicted from the same variables and relationships as are those for lake levels.

Evidence of past floods, catastrophic by present standards, is found in the Snake River and Columbia River basins. The Bonneville Lake overflow occurred some 33-35,000 years ago, deposited 2.4 billion $\mathrm{m}^{3}$ of the so-called Melon gravel (so named because of the huge size of the cobbles), reached crest levels of about $+100 \mathrm{~m}$, and eroded the cataracts in the American Falls. Maximum discharge was estimated at about $1.4 \mathrm{~km}^{3} /$ hour.

Floods that generated the Channeled Scabland in Eastern Washington (at possibly the same time as the Bonneville overflow) occurred after the burst of $700 \mathrm{~m}$ deep Missoula Glacial Lake through the collapsed $1200 \mathrm{~m}$ high ice dam. The flood waters, which formed cataracts and giant ripplemarks, were at least $250 \mathrm{~m}$ high at the Wallula Gap next to Pasco. Maximum discharge was estimated at $40 \mathrm{~km}^{3} /$ hour. Sudden recharge probably raised the regional groundwater levels tens of meters and in some places possibly up to $200 \mathrm{~m}$. Similar floods occurred in the Channeled Scabland area on earlier occasions.

The probability $F$ of reoccurrence of the Missoula type flood in Eastern Washington can be expressed as:

$$
F=f\left\{\int_{t}^{t} c, s, d_{r}, z_{r}, r\right\}
$$

where $\int_{t}^{t} c=$ integrated climates

$$
\begin{aligned}
d_{r}= & \text { distance from a site to a local erosional basis (bottom of } \\
& \text { surface drainage) } \\
z_{r}= & \text { elevation of bottom of surface drainage } \\
s= & \text { site elevation } \\
r= & \text { relief factor. }
\end{aligned}
$$


The sites located in the closed basins have a high probability of being buried by sediment, whereas those in mountain ranges may be exposed by erosion.

Probability $E_{m}$ of a site being either eroded to a depth of $m$ meters or covered by sediment in a thickness of m meters depends critically on geomorphic factors. It can be written that:

$$
\text { where } \begin{aligned}
E_{m} & =f\left\{\int_{t}^{t} c, a_{d}, a_{k}, d_{d}, d_{0}, d_{k}, z_{d}, s, r, d_{1}\right\} \\
\int_{d}^{t} c & =\text { time integrated climate states } \\
a_{k} & =\text { average Late Pleistocene lake area } \\
d_{d} & =\text { distance from a site to a dominant peak } \\
d_{0} & =\text { distance from a site to basin bottom } \\
d_{k} & =\text { distance from a site to the average Late Pleistocene } \\
& \text { shoreline } \\
z_{d} & =\text { elevation of regional dominant peak } \\
s & =\text { site surface elevation and/or location } \\
r & =\text { relief coefficient } \\
d_{1} & =\text { distance to the highest Late Pleistocene shoreline. }
\end{aligned}
$$

The average erosional rates in the Bonneville basin were about $0.05 \mathrm{~mm} / \mathrm{yr}$; in the depressions the depositional rates averaged about $0.1-0.2 \mathrm{~mm} / \mathrm{yr}$.

In summary, the climatic impact on any given site will be predominantly affected by a particular site location, and it is believed that sufficient margin exists to select sites with minimal probability of climate related breach. 
CHAPTER XIV

\title{
ASSESSMENT OF TECTONIC HAZARDS TO WASTE \\ STORAGE IN INTERIOR-BASIN SALT DOMES
}

\author{
R. Kehle
}

Turk, Kehle, and Associates

From the point of view of a structural geologist, mature salt domes located within the interior salt basins in the northern Gulf of Mexico region would make ideal sites for the storage of nuclear waste. Not only is the area tectonically quiet, but the mature domes within the region are judged incapable of reactivation. Storage sites located in the northern gulf region would be free from many geologic hazards, such as earthquakes, active faults, mountain building and uplift, which may affect many otherwise suitable locations. Additionally, the core of a salt dome is impermeable to water, except at shallow depths where cracks and fissures may exist. These flaws in salt domes can heal themselves at burial depths of more than a few hundred feet. The capability of salt to exhibit fluid-like flow at low temperature and stress is also important in sealing off either a repository itself or any flaw in the structure introduced by a geologic event.

The principal reason for the notable absence of earthquakes, volcanoes, active faults, and mountain ranges in the northern gulf region is that the area lies well within the boundaries of the North American tectonic plate. This plate is a large, virtually rigid, crustal mass that is comprised of the Gulf of Mexico, most of the North American continent, and much of the northwestern Atlantic Ocean. Most major tectonic and volcanic activity occurs along the boundaries of such plates, not within their interiors. However, some severe types of tectonic activity do occur within the interiors of major plates. But the northern gulf region is free from such activity, and none is expected to develop during the next million years. 
A few low-magnitude earthquakes have originated in the region. Most of these earthquakes are presumably the result of differential basement subsidence caused by active sediment loading by the Mississippi delta or by water loading resulting from the filling of large surface reservoirs. Comparable seismic events pose no hazard to waste storage in salt domes. A change in the tectonic regime must precede the generation of significantly larger events. No such change is expected to occur within the next several million years.

Faulting of the near-surface sedimentary rock overlying the basement is characteristic of the region, but none is developing presently. Most superficial faulting in the region results directly from growth of salt domes. Few, if any domes, are actively growing today. Furthermore, a truly active dome, or one that has a capacity for reactivation, should not be selected for a repository site. For this reason, no active fault would be present in the vicinity of a storage site. Another important point is that superficial faulting does not penetrate the core of a salt dome. Such faults are confined to the sediments surrounding the dome. Thus they pose no hazard to a storage facility located within a dome.

As well as being located in a benign tectonic region, mature domes in the interior salt basins of the northern gulf area are themselves incapable of destructive mischief. Mature domes are stable and "extinct." They are incapable of renewed growth because, by definition of a mature dome, the reservoir of salt that fed the salt spire has been exhausted.

The evolutionary state of an interior-basin salt dome is readily determined through analysis of a grid of reflection seismic profiles across the dome, provided that the data quality is good and that adequate data reach to below the depth of the pre-salt surface. A significant error in identifying a dome's evolutionary status is highly unlikely. However, even a gross error need not affect the safety of a repository, because the maximum growth rate known to have been experienced by an interior-basin salt dome is 2,000 feet per million years (at Hainesville dome, Wood County, Texas). Even uplift rates of this magnitude would not prohibit the design of an acceptable facility. However, sites with lower uplift rates are available. These high 
uplift rates are limited to immature domes, in which salt is extruding from the underlying salt pillow in response to rapid sediment loading. Such immature domes would not be selected for repository sites, because they are readily identified from seismic profiles.

A more likely error would be to select a dome nearing maturity. Such a dome may still have a small reservoir of salt remaining in the underlying salt pillow. Uplift rates common to domes of this type are much lower than those characteristic of domes in the extrusion state, being on the order of a few tens of feet per million years. Consequently, if a nearly mature dome was selected as a repository host, the associated uplift rates would be insignificant in any design considerations.

STABILITY OF SALT DOMES

Many "piercement" salt domes of the northern interior salt basins could serve as safe, permanent, storage sites for both nuclear and chemically toxic wastes. Suitable domes are stable and inactive, having reached their final evolutionary configuration at least 30 million years ago. They are buried at depths below the level to which erosion will penetrate during the prescribed storage period, and they are not subject to reactivation in the future. The cores of these salt domes are impermeable, permitting neither the entry nor the exit of ground water or other unwanted material.

Stable Domes

Stable domes are those that have reached their final evolutionary configuation. This status is characterized by a salt spine protruding from an eroded hole in the roof of a collapsed salt pillow. The salt pillow is the reservoir that fed salt to the spine during an earlier period of maximum uplift. Such domes are not capable of reactivation, because the reservoir of salt feeding the growth of the spine (the underlying salt pillow) has been completely evacuated. Neither additional sediment loading nor submergence will reactivate such a dome, because the original pillow has already collapsed entirely. Like a flat tire from which all air has escaped, no further collapse of the initial salt pillow is possible after all of the salt has been squeezed from it. 
Nor will the salt spine float up through the overlying sedimentary rocks. In fact, buoyancy, per se, is never really operative in the evolutionary history of a dome. The stresses caused by buoyancy are insufficient to rupture the cover of sedimentary rocks. More importantly, the sediments surrounding the dome will not flow into the void that would be created if the dome should begin to rise. In fact, the salt spine itself, being more fluid than the surrounding sediments, would flow back into the void. It would thus terminate any tendency for the spine to ascend.

\section{Recognizing Stable Domes}

Stable domes are characterized by three factors: 1) a completely evacuated predecessor structure, 2) steep or overhanging flanks, and 3) continuous sedimentary layers across the crest of the structure.

Determining the growth history of a candidate dome verifies its evolutionary state. The growth history can be reconstructed by using high-quality reflection seismic profiles. The profiles must cross the dome and the surrounding area in a variety of directions. These profiles would provide the data needed for a complete three-dimensional reconstruction.

Use of seismic profiling permits the identification of a predecessor salt structure for each piercement dome. These predecessors may be pillows, anticlines, or similar structures. The time at which the sedimentary cover of the predecessor structure is breached is readily ascertained from seismic data. The collapse of the predecessor structure can also be tracked. Tracking of the predecessor's collapse establishes conclusively whether all or most of the salt has been evacuated from the predecessor structure, which in turn demonstrates whether there is any possibility of the reactivation of dome growth. At the same time, the rate of uplift of the salt stock can be determined by dividing the surface area of the stock by the volume reduction of the predecessor structure at a number of successive times. A plot of uplift rate versus time for a mature dome will exhibit a maximum in the rate of uplift (as much as 2,000 feet per million years) during periods of maximum salt extrusion. A steady reduction of the uplift rate occurs after this maximum. The uplift rate declines to zero when all of the salt has been evacuated from the predecessor structure. 
Each dome follows this evolutionary history. As soon as a dome is past the extrusion phase, it is incapable of reactivation. Deceleration of the growth rate continues until it ceases altogether. Existing observational skills are inadequate to identify the final date at which the last millimeter of uplift occurred, but that final date has no bearing on the problem at hand. As soon as the growth rate of a dome decelerates to a negligible value, the potential for further growth is limited to such a small value as to have no bearing on the safety of the repository.

Not only are stable, mature domes free from "internal" hazard, they are also free from "external" tectonic processes that might endanger a repository. This freedom from tectonism can be attributed to their location within the North American lithospheric plate and to the evolutionary state of the interior salt basins.

STRUCTURAL STABILITY OF THE NORTHERN INTERIOR SALT BASINS

The northern interior salt basins of the Gulf of Mexico region are generally free from diastrophic activity that might pose a hazard to the safe storage of nuclear wastes. This fact is not surprising, because these basins are located well within the North American tectonic plate. They are far away from both interplate and intraplate tectonic activity. Although the sediments in each of these basins are moderately deformed, most of the deformation resulted from non-diastrophic causes, principally movement within underlying salt layers. Those few structures resulting from crustal deformation are no longer active. These structures are related to one of several ancient periods of deformation in the region. The only movement continuing today is subsidence of the coastal basin, which results in oceanward-tilting of the entire region. This tilting, in turn, causes some adjustment between basement blocks. These adjustments are accompanied by the release of seismic energy, but the resultant low-magnitude earthquakes pose no hazard to man-made structures. Disruptive Tectonic Activity Within the North American Plate

Most violent tectonic activity occurs along the boundaries of tectonic plates. The North American plate is no exception. Basaltic volcanoes, tensional faults, and earthquakes of modest magnitude characterize the divergent 
eastern margin of the plate, which is the mid-Atlantic ridge. Explosive andesitic volcanoes, great earthquakes, disruptive faults, and folds characterize large segments of the western plate margin on the Pacific Coast and the southern margin in the Caribbean. Active strike-slip faults and thrusts with attendant major earthquakes characterize the balance of the Pacific and Caribbean margins.

These active tectonic zones lie at great distances from the northern interior salt basins. For this reason they pose no hazard for disposal facilities located there.

Violent tectonic activity is not restricted entirely to plate margins. Many destructive processes operate within the interior of tectonic plates. Most of these processes are confined to specific regions, for clearly identifiable reasons. For example, the broad regions overlying subducting plates near convergent margins experience volcanic eruptions, active faulting, and large earthquakes. The Mexican volcanic belt and the Pacific Northwest of the United States are examples of such regions. Large areas affected by back-arc spreading are characterized by block faults, earthquakes, and modest volcanoes. The Great Basin of the western United States may be such a region. Rifting, perhaps signaling incipient crustal breakup, is also characterized by extensive faults, volcanic activity, and earthquakes. The Rio Grande rift is probably such an area.

None of these active regions infringes on the northern Gulf of Mexico region, and the tectonic activity within these regions is not likely to spread significantly within the next million years.

Another predictable phenomenon is volcanic activity related to plate migration over hot spots on the mantle. Migration of the plate over a hot spot is the likely origin of volcanoes in Yellowstone and north-central New Mexico. The paths of migration and relative rates of movement of these volcanic centers show that they, too, will have no influence on the northern Gulf of Mexico region at any time in the next million years. 
Cratonic basins also occur within the interiors of lithospheric plates. Presumably, diastrophic activity accompanies their formation and development. This relationship is suggested by the fact that many cratonic basins appear to be located over the remnents of a block-faulted crust, identifying these regions as ancient abandoned rifts or spreading centers. In such regions, most of the diastrophic activity precedes the formation of a basin. During filling of a basin, only subsidence-related crustal adjustments lead to faults and earthquakes. These events are infrequent and of low magnitude. As soon as they are filled to capacity with sediments, the cratonic basins cease to evolve. At that time they become part of the stable interior of a lithospheric plate.

Tectonic Activity Within the Interior Salt Basins of the Northern Gulf of Mexico

The interior salt basins of the northern Gulf of Mexico region are completely filled, inactive, intraplate basins. These basins, the East Texas, North Louisiana, and Mississippi salt basins, are underlain by a block-faulted basement, bordered by a nearly continuous fault system, and contain within them numerous salt-supported structures surrounded by local faults of varying types and orientations.

Most of the structures within the interior basins are extinct. The processes that caused them are no longer operative. Minor activity along the southern borders of the basins is attributed to adjustments within the basement needed to accommodate the continued subsidence of the Gulf of Mexico basin to the south. It is questionable whether any of the salt structures are active today. A few of these structures are capable of reactivation, should the area become innundated and sedimentation resume, but most are either mature ("extinct") or nearly so. Faults and other features related to those few salt structures that are capable of reactivation would become reactivated with renewed salt movement.

Basement Block Faulting

There was major, pervasive, extensional faulting throughout the Gulf region during the early Mesozoic. This faulting resulted in significant 
crustal attentuation, thereby converting the previous continental area into the series of basins that exists today. This episode of major crustal disruption ceased entirely during the Middle Jurassic, about 150 million years ago. Some faults within this system were reactivated during the Middle Cretaceous, about 100 million years ago. This latter episode was short lived, probably confined to less than a five million year interval.

Throughout the history of the area, these same basement faults served as the locus for adjustments between basement blocks during periods of basin subsidence. They accommodated differential subsidence of crustal blocks of different thicknesses by permitting decoupling between the blocks. Although the interior basins ceased subsiding about 45 million years ago, some decoupling still occurs today. This decoupling is the result of active subsidence of the Gulf basin to the South.

The interior basins reached isostatic equilibrium in the early Tertiary, because they were filled to capacity with sediment by that time. But the Gulf basin to the south was nearly empty. Throughout the Tertiary and continuing today, high volumes of sediment were deposited in the north part of the empty Gulf basin, causing the loaded area to subside rapidly. The crust beneath the northern Gulf is coupled to the southern boundary of the interior basins, so the subsidence of the Gulf basin dragged the southern boundary of the interior basins below its isostatic compensation level. The greater the depression of a crustal segment below its compensation level, the greater the restoring isostatic forces. These forces, in turn, promote decoupling along planes of weakness (the Mesozoic basement faults). Decoupling is accommodated piecemeal by small movements along the old faults accompanied by minor releases of seismic energy. This kind of activity is probability the cause of the few minor earthquakes reported from this region.

Future earthquakes should be no larger than the earthquakes associated with decoupling have been, because the rate of energy storage is slow. It is related directly to basin subsidence, which is governed by sedimentation rates. These are slow processes compared to relative plate motions typical of tectonically active regions. The result is that in the Gulf region, the rate of 
build-up of strain energy is comparably slow. Large strain imbalances, which are relieved by massive releases of seismic energy, do not occur where strain build-up is so slow. The low rate of occurrence and low magnitude of the earth tremors recorded in the Gulf region are in accordance with the slow rate of strain build-up, and no changes should be expected in the future.

\section{Boundary Fault System}

The system of faults bounding the northern interior salt basin is only indirectly related to the basement-fault systems described above. The boundary faults are at the outer periphery of the Triassic block-faulted terrain. They have a long evolutionary history, having been active about 110 million years, from mid-Jurassic through Eocene time. Movement along the faults within the boundary-fault system apparently resulted from either salt flow away from a buried basement scarp or from bending (because of differential subsidence) across a boundary between thin crust underlying the basins and thick crust underlying the surrounding continental mass.

Neither process is operative today: 1) There is no bending because there is no subsidence. The basins are filled to capacity with sediment, so no accommodation by subsidence is necessary; 2) No salt flows from beneath the fault system because all of the salt has been evacuated previously. This evacuation is shown by both seismic and well data.

Because of the nature of the causitive mechanisms, the faults in the boundary system are not subject to reactivation. For example, no more salt can escape from beneath the boundary faults, because all of the salt that was there has already been evacuated. Thus, this mechanism cannot cause further displacements. Similarly, no additional subsidence can occur in the basins because they are already full to capacity. This lack of potential for subsidence can be explained by the fact that the basins, as we 11 as the surrounding continental land mass, are in isostatic equilibrium. The absence of offsets in Pleistocene alluvial fans and river terraces along the boundary-fault system confirms the lack of movement in the recent geologic past. Comprehension of the cause of movement along the boundary-system faults makes it possible to state unequivocally that no future movement is possible until the tectonic regime changes. 


\section{Balcones System}

The Balcones fault system, which separates the Edwards Plateau from the Gulf of Mexico province, was active during the Miocene and possibly into the Pliocene. But no offsets of Pleistocene fans or terraces have been observed, indicating that the system has been inactive for at least two million years. Presumably, the faulting was related to the epeirogenic uplift of the western United States. Although related tectonic activity continues today, it apparently does not result in further tilting of the High Plains of Texas. Consequently, the Balcones fault system is no longer active.

The Balcones fault system is capable of reactivation, should uplift of New Mexico and Trans-Pecos Texas resume. It would be very difficult to give a probability for resumed uplift of the area and subsequent reactivation of the fault system. Details of the evolutionary history of incipient rifts are inadequately known to allow making absolute statements regarding the future history of this area.

The Balcones fault system is located far from most candidate domes, so it poses no direct hazard to storage facilities located within the basins. However, design of a storage facility ought to include protection against remote possible damage from medium magnitude earthquakes (5.0-5.5) generated along the Balcones system.

\section{Salt Structures and Related Faults}

Virtually all of the remaining structures within the interior salt basins are related to movement of the Jurassic Louann salt. Movement within the salt is accommodated by deformation in the overlying sediments. Structures of this type are local, and their formation is aseismic. Ground displacement is the only hazard they pose to man-made structures. Consequently, the only structures that need to be considered are those associated with candidate domes. Generally, these faults occur only within the sediments surrounding a dome and do not penetrate the salt core itself. Faults that do not penetrate the salt core will not affect the structural integrity of a repository. Faulting in the sediments will result in an offset of ground water flow, which may or may not be of consequence to the selection and design of a repository. Such determinations will need to be made on a site-by-site basis. 


\section{DISTRIBUTION LIST}

No. of

Copies

OFFSITE

2 Argonne National Laboratory

Reference Library

9800 S. Cass Ave.

Argonne, IL 60439

Battelle Memorial Institute

Office of Nuclear Waste I solation

505 King Ave.

Columbus, $\mathrm{OH} 43201$

Attn: Beverly Rawles

2 Brookhaven National Laboratory

Reference Section

Information Division

Upton, Long Is land, NY 11973

27 DOE Technical Information Center

John Bird

Geology Department

Cornel1 University

Ithaca, NY 14853

Pat Brannen

Sandia Laboratory

P.0. Box 5800

Albuquerque, NM 87115

John Bredehoeft

U.S. Geological Survey

Reston, VA 22092

Robert Budnitz

U.S. Nuclear Regulatory

Commission

Washington DC 29545
No. of

Copies

Colin Bull

Office of the Dean

College of Math and Physical Sciences

Ohio State University

164 W. 17th Ave.

Columbus, $\mathrm{OH} 43201$

Harry C. Burkholder

Office of Nuclear Waste Isolation

Battelle Memorial Institute

505 King Ave.

Columbus, $\mathrm{OH} 43201$

Jim Campbel1

T39

Division 5413

Sandia Labs

Albuquerque, NM 87185

20 Wayne A. Carbiener

Office of Nuclear Waste Isolation

Battelle Memorial Institute

505 King Avenue

Columbus, $\mathrm{OH} 43201$

A. A. Churm

DOE Patent Division

9800 So. Cass Ave.

Argonne, IL 60439

H. Clyde Claiborne

Oak Ridge National Laboratory

P.0. Box $X$, Building 3017

Oak Ridge, TN 37830 
No. of

Copies

James Clark

c/o Eugene Vetter

Route 2, Box 70

Shawano, WI 54166

Neville G. W. Cook

Dept. of Materials Science and Mineral Engineering

Hearst Mining Building

University of California

Berkeley

Berkeley, CA 94720

Carl R. Cooley

DOE Office of Waste Management

Washington DC 20545

Howard A. Coombs

Department of Geological

Sciences

University of Washington

Seattle, WA 98194

James W. Crosby III

1467 Alpowa

Moscow, ID 83843

Bruce Crowe

Geological Research Group, G-6

Los Alamos Scientific

Laboratory

P.0. Box 1663

Los Alamos, NM 87545

Jared Davis

27 Nuclear Regulatory Commission

Washington DC 20555

Stan ley M. Davis

810 N. Camino Santiago, \#20

Tucson, AZ 85705

G. L. DeBuchananne

U.S. Geological Survey

Reston, VA 22092
No. of

Copies

Terry Donich

Lawrence Livermore Laboratory

P.0. Box 808

Livermore, CA 94550

James Duguid

Office of Nuclear Waste Isolation

Battelle Memorial Institute

Columbus, $\mathrm{OH} 43201$

Don Easterbrook

Western Washington University

Bellingham, WA 98225

Dan Egan

U.S. Environmental Protection Agency

Washington DC 20545

Environmental Protection Agency

Office of Radiation Programs

Technical Assessment Division AW559

Washington DC 20460

J. G. Feinstein

NUS Corporation

4 Research Place

Rockville, MD 20850

Graham E. Fogg

Bureau of Economic Geology

The University of Texas Austin

University Station, Box $X$

Aust in, TX 78712

Robert M. Garrells

Dept. of Geologic Sciences

Northwestern University

Evanston, IL 60201 
No. of

Copies

Raymond D. Gastil

Freedom House

20 W. 40th St.

New York, NY 10018

Earnest Gloyna

National Academy of Sciences

University of Texas

Aust in, TX 78712

George Griswold

Tecolote Corporation

531 Wagon Train Drive SE

Albuquerque, NM 87123

Char les R. Had lock

Arthur D. Little, Inc.

Acorn Park

Cambridge, MA 02140

Colin A. Heath

DOE Division of Waste Management

Washington DC 20545

William M. Hewitt

Office of Nuclear Waste Isolation

Battelle Memorial Institute

505 King Ave.

Columbus, $\mathrm{OH} 43201$

John M. Hills

818 Kerbey Ave.

El Paso, TX 79902

John T. Holloway

Committee on Radioactive Waste

Management $\mathrm{JH}-826$

National Academy of Sciences

2101 Constitution Ave. NW

Washington DC 20418

Vojin Joksimovic

General Atomic Company

P.0. Box 81608

San Diego, CA 92138
No. of

Copies

Louis S. Karably

Law Engineering

2749 Delk Road SE

Marietta, GA 30067

R. F. Kaufman

Evaluation Branch

Office of Radiation Programs

U.S. Environmental Protection Agency

P.0. Box 18416

Las Vegas, NV 89114

Ralph Kehle

7800 Shoul Creek Blvd.

Suite $270 \mathrm{~S}$

Austin, TX 78757

Muzaffer Kehnemuyi

Office of Nuclear Waste Isolation

Battelle Memorial Institute 505 King Ave.

Columbus, $\mathrm{OH} 43201$

John F. Kircher

Office of Nuclear Waste Isolation

Battelle Memorial Institute 505 King Ave.

Columbus, $\mathrm{OH} 43201$

Charles Koplick

The Analytic Sciences Corp.

6 Jacob Way

Reading, MA 01867

Charles W. Kreitler

Texas Bureau of Economic Geology

University Station, Box $X$

Aust in, TX 78712 
No. of

Copies

George K. Kukla

Lamont-Doherty Geologica 1

Observatory

Palisades, NY 10964

Donald H. Kupfer

Department of Geology

Louisianna State University

Baton Rouge, LA 70803

James G. LaBastie

Law Engineering and Testing Co.

2749 Delk Road SE

Marietta, GA 30067

Ronald B. Lantz

INTERA Environmental

Consultants, Inc.

11511 Katy Freeway

Houston, TX 77079

2 Lawrence Berkeley Laboratory

Reference Library

University of California

Berkeley, CA 94720

2 Lawrence Livermore Laboratory

Reference Library

P.0. Box 808

Livermore, CA 94550

Darre11e I. Leap

USGS, WRD, MS416

Box 25046

Denver Federal Center

Denver, CO 80225

Richard Lincoln

Sandia Laboratories

N.N.W.S.I.

NTS Technical Overview

Division 4538

Albuquerque, NM 87185
No. of

Copies

Stanley E. Logan

Nuclear Waste Management

Program

Los Alamos Technical

Associates, Inc.

P.0. Box 410

Los Alamos, NM 87554

Ear 1 M. Lovejoy

4400 Fairview Road

Reno, NV 89511

Peter D. Mattison

Arthur D. Little, Inc.

Acorn Park

Cambridge, MA 02140

W. C. McClain

Oak Ridge National Laboratory

P.0. Box $X$

Oak Ridge, TN 37830

John T. McGinn is

Office of Nuclear Waste Isolation

Battelle Memorial Institute 505 King Ave.

Columbus, $\mathrm{OH} 43201$

She ldon Meyers

DOE Office of Nuclear Waste Management

Washington DC 20545

Peter A. Mote

Bechte1, Inc.

P.0. Box 3965

San Francisco, CA 94105

2 Barry Naft

NUS Corporation

4 Research Place

Rockville, MD 20805 
No. of

Copies

J. 0. Neff

Department of Energy

Columbus Program Office

505 King Ave.

Columbus, $\mathrm{OH} 43201$

Robert H. Neil

State of New Mexico

Environmental Evaluation Group

P.0. Box 968

Santa Fe, NM 87503

Ivars Neretnieks

Earth Science Division

Lawrence Berkeley Laboratory

University of California

Berkeley, CA 94720

2 Neil Norman

Environmental Sciences Dept.

Bechtel National, Inc.

P.0. Box 3965

San Francisco, CA 94105

2 Los Alamos Scientific Laboratory

Reference Library

P.0. Box 1663

Los Alamos, NM 87544

2 Oak Ridge National Laboratory

Central Research Library

Document Reference Section

Oak Ridge, TN 37830

Suresh B. Pahwar

INTERA Environmental Consultants, Inc.

11511 Katy Freeway, Suite 630

Houston, TX 77079

Frank L. Parker

Dept. of Environmental

Engineering

Vanderbilt University

Nashville, TN 37235
No. of

Copies

\section{James Pearson}

INTERA Environmental Consultants, Inc.

11511 Katy Freeway, Suite 630 Houston, TX 77079

George F. Pinder

Dept. of Civil Engineering

Stanford University

Stanford, CA 94305

Larry Ramspott

Technical Program Officer

Lawrence Livermore Laboratory

P.0. Box 808

Livermore, CA 94550

Linda Robinson

NUS Corporation

4 Research Place

Rockville, MD 20850

Savannah River Laboratory

Reference Library

Aiken, SC 29801

Maurice L. Schwartz

Department of Geology

Western Washington University

Bellingham, WA 98225

Genevieve Segol

Bechte 1, Inc.

P.0. Box 3965

San Francisco, CA 94105

Herb Shaw

U.S. Geological Survey

Mail Stop 18

345 Middlefield Road

Men lo Park, CA 94025 
Dillard B. Shipler

Office of Nuclear Waste I so 1 ation

Battelle Memorial Institute 505 King Ave.

Columbus, $\mathrm{OH} 43201$

James N. Siltanen

Genera 1 Atomic Company

P.0. Box 81608

San Diego, CA 92138

George M. Slaughter

Law Engineering and Testing Co.

2749 Delk Road SE

Marietta, GA 30067

Barry J. Smernoff

Hudson Institute

Quaker Ridge Road

Croton-On-Hudson, NY 10520

Terry Ste inborn

Lawrence $L$ ivermore Laboratories

P.0. Box 808

Livermore, CA 94550

Howard P. Stephens

Sandia Laboratories

N.N.W.S.I.

Division 4538

Albuquerque, NM 87185

James I. Stevens

Arthur D. Little, Inc.

Acorn Park

Cambridge, MA 02140

David B. Stewart

U.S. Geological Survey National Center 959

Reston, VA 22092
Robert $L$. Thoms

Institute for Environmental

Studies

Louisianna State University

Baton Rouge, LA 70803

Newe 11 Trask

U.S. Department of the Interior Geological Survey

Mai1 Stop 929

Reston, VA 22092

W. S. Twinhofel

USGS

Mai1 Stop 954

Denver, CO 80225

Maurice D. Veatch

6834 - 51st Ave. NE

Seattle, WA 98115

W. Weart

Division 1140

Sandia Laboratories

A1buquerque, NM 87115

Lawrence Wight

TERA

2150 Shaltuck Ave.

Berkeley, CA 94704

Charlie Wilson

Earth Sciences Division

Lawrence Livermore Laboratory

Building 90

Berkeley, CA 94720

Paul Witherspoon

Earth Sciences Division

Lawrence Livermore Laboratory Building 90

Berkeley, CA 94720 
No. of

Copies

FOREIGN

Bundesministerium fur Forschung und Technologie

Stressemannstrasse 2

D-5300 Bonn

F.R. of Germany

GERMANY

Leif Carlsson

Geological Survey of Sweden

Bredgrand 4

S-753 20 UPPSALA

$018 / 155640$

SWEDEN

Ken Dornuth

Atomic Energy Canada Ltd.

Whiteshe 11 Nuclear Research Establishment

Pinawa, Manitoba ROE $1 L 0$

CANADA

F. Gera

Nuclear Energy Agency/OECD

38 boulevard Suchet

75016 Paris

FRANCE

2 INIS Clearinghouse

Internationa 1 Atomic Energy Agency

P.0. Box 590

A-1011, Vienna

AUSTRIA

Library

Studsvik Energiteknik $A B$

S-611 01 Nykoping

SWEDEN
No. of

Copies

Takehico Ngamatsu

Geologist

Chief Representative Vancouver office

Mitsubishi Metal Corporation

78 Granville Square

200 Granville Street

Vancouver, BC V6C 1S4

CANADA

F. P. Sargent

Atomic Energy of Canada, Ltd. Whiteshel1 Nuclear Research

Establ ishment

Pinawa, Manitoba ROE 1LO

CANADA

Noritaka Sato

Chief Geologist, Domestic

Exploration \& Nuclear

Resources

Mitsubishi Metal Corporation

1-5-2 Ohte-Machi

Chiyoda-Ku, Tokyo

JAPAN

Egbert Schapermeier

Battelle-Institute e.V.

Am Romerhof 35

D-6000 Frankfurt am Main 90

F. R. of Germany

GERMANY

\section{ONSITE}

5 Department of Energy

0. J. Elgert

H. E. Ransom

J. J. Schreiber

D. J. Squires

F. R. Standerfer 
No. of

Copies

7 Rockwe 11 Hanford Operations

R. L. Biggerstaff

D. J. Brown

R. A. Deju

G. S. Hunt

R. E. Isaacson

G. L. Jones

Rockwe 11 Document Control

71 Pacific Northwest Laboratories

E. M. Arnold

G. L. Benson

D. J. Bradley

A. Brandstetter (10)

J. B. Brown

D. B. Cear lock

V. L. Coburn

R. A. Craig

W. Deutsch

F. H. Dove

D. W. Dragnich

J. R. Eliason

E. A. Eschbach

H. P. Foote

J. Greenborg

R. J. Hall

M. A. Harwe 11

A. J. Haverfield

B. W. Howes
No. of

Copies

J. H. Jarrett

M. R. Kreiter

I. Levy

J. W. Lindberg

R. P. Marsha 11

L. M. Martucci

R. F. McCallum

J. L. McElroy

J. McGinn is

K. S. Murthy

R. W. Nelson

R. E. Nightingale

H. M. Parker

G. Petrie

A. M. Platt

J. R. Raymond

J. F. Relyea

B. L. Scott

R. J. Serne

J. G. Stephan

J. A. Stott lemyre

R. P. Turcotte

R. W. Wallace

R. A. Walter

W. R. Wiley

J. T. Zellmer

Technical Information Library (5)

Publishing Coordination RO (2)

Water and Land Resources

Department Library (10) 